Cover: Aerial view of Bear Creek in Story County, lowa.

Photograph taken by Lynn Betts, U.S. Department of Agriculture,

Natural Resources Conservation Service. 
The Quality of Our Nation's Waters

\section{Understanding the Influence of Nutrients on Stream Ecosystems in Agricultural Landscapes}

By Mark D. Munn, Jeffrey W. Frey, Anthony J. Tesoriero, Robert W. Black, John H. Duff, Kathy E. Lee, Terry R. Maret, Christopher A. Mebane, Ian R. Waite, and Ronald B. Zelt

National Water-Quality Program

National Water-Quality Assessment Project

Circular 1437 


\section{U.S. Department of the Interior RYAN K. ZINKE, Secretary}

\section{U.S. Geological Survey James F. Reilly II, Director}

\section{U.S. Geological Survey, Reston, Virginia: 2018}

For more information on the USGS - the Federal source for science about the Earth, its natural and living resources, natural hazards, and the environment-visit https://www.usgs.gov or call 1-888-ASK-USGS.

For an overview of USGS information products, including maps, imagery, and publications, visit https://store.usgs.gov.

Any use of trade, firm, or product names is for descriptive purposes only and does not imply endorsement by the U.S. Government.

Although this information product, for the most part, is in the public domain, it also may contain copyrighted materials as noted in the text. Permission to reproduce copyrighted items must be secured from the copyright owner.

Suggested citation:

Munn, M.D., Frey, J.W., Tesoriero, A.J., Black, R.W., Duff, J.H., Lee, Kathy, Maret, T.R., Mebane, C.A., Waite, I.R., and Zelt, R.B., 2018, Understanding the influence of nutrients on stream ecosystems in agricultural landscapes: U.S. Geological Survey Circular 1437, 80 p., https://doi.org/10.3133/cir1437.

ISSN 2330-5703 (online) 


\section{Foreword}

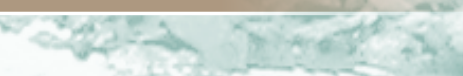

Sustaining the quality of the Nation's water resources and the health of our diverse ecosystems depends on the availability of sound water-resources data and information to develop effective, science-based policies. Effective management of water resources also brings more certainty and efficiency to important economic sectors. Taken together, these actions lead to immediate and long-term economic, social, and environmental benefits that make a difference to the lives of the almost 400 million people projected to live in the United States by 2050.

In 1991, Congress established the U.S. Geological Survey (USGS) National Water-Quality Assessment (NAWQA) to address where, when, why, and how the Nation's water quality has changed, or is likely to change in the future, in response to human activities and natural factors. Since then, NAWQA has been a leading source of scientific data and knowledge used by national, regional, State, and local agencies to develop science-based policies and management strategies to improve and protect water resources used for drinking water, recreation, irrigation, energy development, and ecosystem needs (https://water.usgs. gov/nawqa/applications/). Plans for the third decade of NAWQA (2013-23) address priority water-quality issues and science needs identified by NAWQA stakeholders, such as the Advisory Committee on Water Information and the National Research Council, and are designed to meet increasing challenges related to population growth, increasing needs for clean water, and changing land-use and weather patterns.

Excess nutrients are a pervasive problem of streams, lakes, and coastal waters. The current report, "The Quality of Our Nation's Waters-Understanding the Effects of Nutrients on Stream Ecosystems in Agricultural Landscapes," presents a summary of results from USGS investigations conducted from 2003 to 2011 on processes that influence nutrients and how nutrient enrichment can alter biological components of agricultural streams. This study included collecting data from 232 sites distributed among eight study areas. This report summarizes findings on processes that influence nutrients and how nutrient enrichment can alter biological communities in agricultural streams. These findings are relevant to local, State, regional, and national decision-makers involved in efforts to (1) better understand the influence of nutrients on agricultural streams, (2) develop nutrient criteria for streams and rivers, (3) reduce nutrients to streams and downstream receiving waters, and (4) develop tools for tracking nutrient and biological conditions following nutrient reduction strategies. All NAWQA reports are available online at https://water.usgs.gov/ nawqa/bib/.

We hope this publication will provide you with insights and information to meet your water-resource needs and will foster increased citizen awareness and involvement in the protection and restoration of our Nation's waters. The information in this report is intended primarily for those interested or involved in resource management and protection, conservation, regulation, and policymaking at the regional and national levels.

Dr. Donald W. Cline

Associate Director for Water

U.S. Geological Survey 


\section{Contents}

Foreword

Chapter 1. Overview of Findings and Implications

Chapter 2. Nutrient Primer ...

Chapter 3. Approach to Assessing Nutrients and Their Ecological Effects in Agricultural Streams.

Chapter 4. Nutrients in Surface Waters_-Pathways and Processes.............................................31

Chapter 5. Influence of Nutrients and Habitat on Aquatic Vegetation in

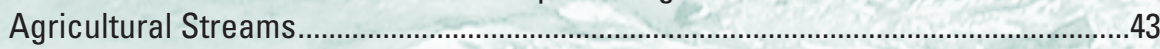

Chapter 6. Influence of Nutrients and Habitat on Biological Communities …………………….......5

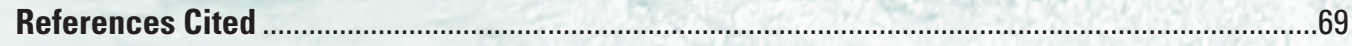

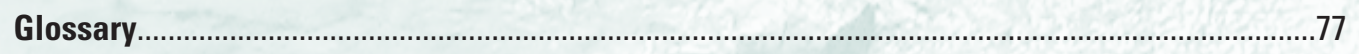




\section{Conversion Factors}

U.S. customary units to International System of Units

\begin{tabular}{|c|c|c|}
\hline Multiply & By & To obtain \\
\hline 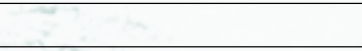 & Flow rate & \\
\hline cubic foot per second ( $\left.\mathrm{ft}^{3} / \mathrm{s}\right)$ & 0.02832 & cubic meter per second $\left(\mathrm{m}^{3} / \mathrm{s}\right)$ \\
\hline
\end{tabular}

International System of Units to U.S. customary units

\begin{tabular}{lll}
\hline \multicolumn{1}{c}{ Multiply } & By & To obtain \\
\hline centimeter (cm) & Length & inch (in.) \\
millimeter (mm) & 0.3937 & inch (in.) \\
meter (m) & 0.03937 & foot (ft) \\
kilometer $(\mathrm{km})$ & 3.281 & mile (mi) \\
\hline & 0.6214 & \\
\hline square meter $\left(\mathrm{m}^{2}\right)$ & Area & acre \\
square meter $\left(\mathrm{m}^{2}\right)$ & 0.0002471 & square foot (ft $\left.{ }^{2}\right)$ \\
square kilometer $\left(\mathrm{km}^{2}\right)$ & 10.76 & square mile (mi $\left.{ }^{2}\right)$ \\
\hline gram (g) & 0.3861 & \\
kilogram (kg) & Mass & ounce, avoirdupois (oz) \\
milligram (mg) & 0.03527 & pound avoirdupois (lb) \\
\hline
\end{tabular}

Temperature in degrees Celsius $\left({ }^{\circ} \mathrm{C}\right)$ may be converted to degrees Fahrenheit $\left({ }^{\circ} \mathrm{F}\right)$ as

$$
{ }^{\circ} \mathrm{F}=\left(1.8 \times{ }^{\circ} \mathrm{C}\right)+32 .
$$

Concentrations of chemical constituents in water are given in either milligrams per liter (mg/L) or micrograms per liter $(\mu \mathrm{g} / \mathrm{L})$. 


\section{Abbreviations}

ADP

ATP

All

BFI

BMP

DNA

EPA

EPT

$\left(\mathrm{g} 0 / \mathrm{m}^{2}\right) / \mathrm{d}$

$\mathrm{mg} / \mathrm{m}^{2}$

NAWQA

NCLD

O/E

RNA

SEM

adenosine diphosphate

adenosine triphosphate

Agricultural Intensity Index

base-flow index

best management practices

deoxyribonucleic acid

U.S. Environmental Protection Agency

Ephemeroptera, Plecoptera, and Trichoptera

grams oxygen per square meter per day

milligrams per square meter

National Water-Quality Assessment

National Land Cover Data

observed/expected

ribonucleic acid

USGS

Structural Equation Model

U.S. Geological Survey 


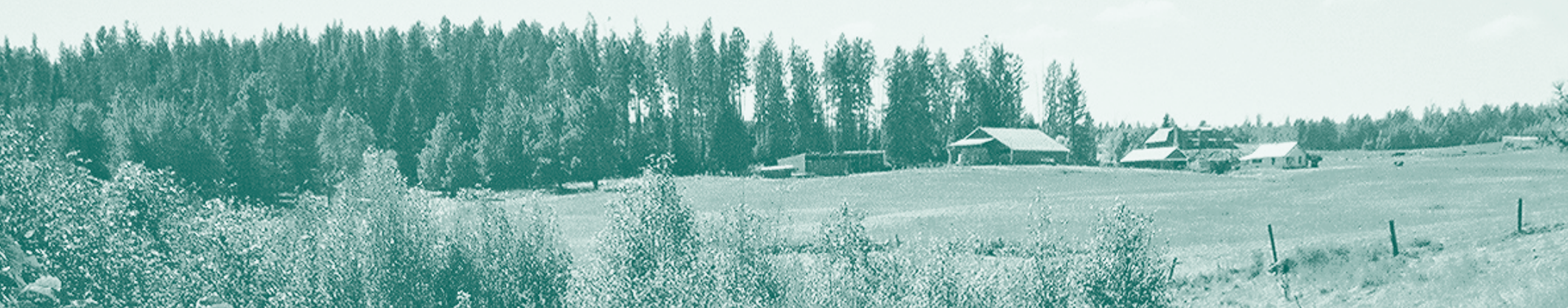

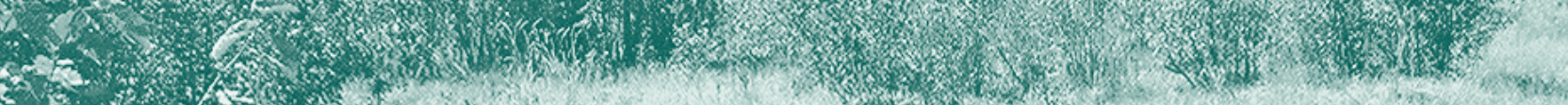

X.

(x)

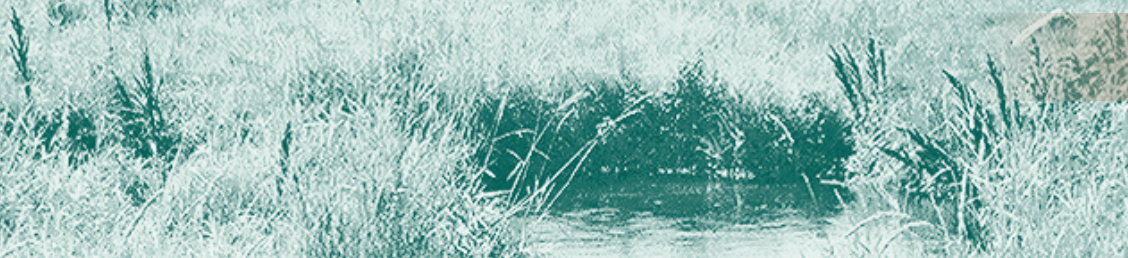

s.

(1)

(2).

H.

(2)

1.

(1)

(2)

(x)

1.12)

(1)

-

\section{Deer Creek, Washington}

$x^{2}+x^{2}+x^{2}$

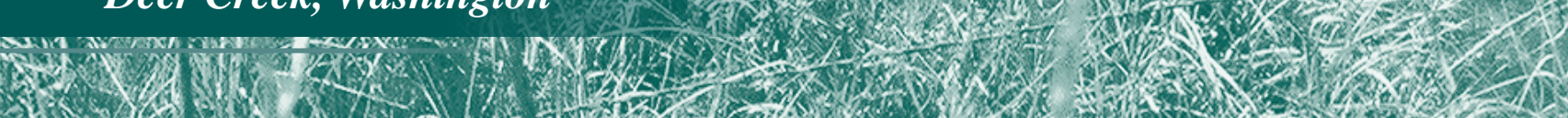
for 


\title{
Understanding the Influence of Nutrients on Stream Ecosystems in Agricultural Landscapes
}

\author{
By Mark D. Munn, Jeffrey W. Frey, Anthony J. Tesoriero, Robert W. Black, John H. Duff, Kathy Lee, \\ Terry R. Maret, Christopher A. Mebane, Ian R. Waite, and Ronald B. Zelt
}

\section{Chapter 1. Overview of Findings and Implications}

In the contiguous United States there are approximately 5 million $\mathrm{km}$ of streams and rivers, which contain a diversity of aquatic species including microbes, aquatic vegetation (algae and plants), invertebrates, and fish. All of these play key roles in structuring the food web that sustains aquatic life, wildlife, and in some cases humans. Over the last 50 years, human actions have profoundly altered the natural input and cycling of nutrients (nitrogen and phosphorus) through the environment and greatly increased the amount of nutrients transported to our streams, rivers, and estuaries. Although nutrients are essential for a healthy aquatic ecosystem, excess nutrients can affect aquatic and human health. Impacts to aquatic health include nuisance and toxic algal blooms, oxygen depletion, loss of important instream habitat, and shifts in aquatic food resources. Excess nitrogen in streams also can increase drinking water treatment costs. Excess nutrients have a major economic impact_causing an estimated $\$ 2.2$ billion per year in damages related to recreational water usage, waterfront real estate, and drinking water treatment (Dodds and others, 2009).
The increased need for understanding nutrient issues gave rise to a U.S. Geological Survey (USGS) National Water-Quality Assessment (NAWQA) Project study to assess nutrients and their ecological effects in agricultural streams. Streams in agricultural landscapes have some of the highest levels of nitrogen and phosphorus, resulting in concerns for both stream health and downstream receiving waters. Eight agriculturally influenced areas across the Nation were selected to encompass a diversity of agricultural practices and environmental settings.

The studies were done in the Central Columbia-Yakima River Basins in eastern Washington (Columbia Plateau); the Upper Snake River Basin (Snake River) of southeastern Idaho and northeastern Nevada; in Central Nebraska; the Ozark Highlands in Arkansas, Missouri, and Oklahoma (Ozarks); the Upper Mississippi River Basins in Minnesota and Wisconsin (Upper Mississippi); the White River and Great and Little Miami River Basins of Indiana and Ohio (White-Miami); the Delmarva Peninsula (Delmarva); and the Georgia Coastal Plain (Georgia Coastal) that also includes part of Alabama and Florida.

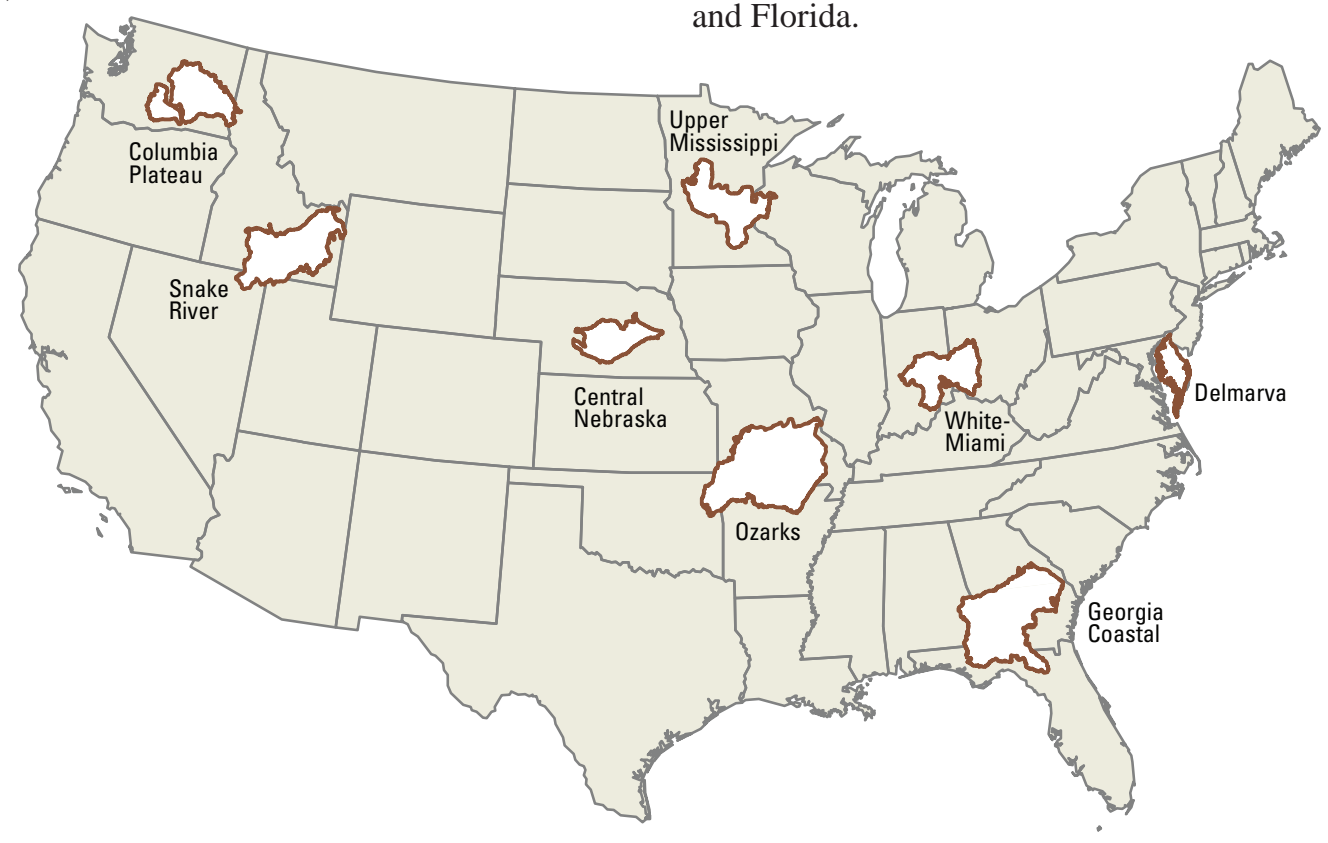


This report summarizes findings on processes that influence nutrients and how nutrient enrichment can alter algal and invertebrate communities in agricultural streams. These findings are relevant to local, State, regional, and national decision-makers involved in efforts to (1) better understand the influence of nutrients on agricultural streams, (2) develop nutrient criteria for streams and rivers, (3) reduce nutrients to streams and downstream receiving waters, and (4) develop tools for tracking nutrient and biological conditions following nutrient reduction strategies.

\section{Algal and invertebrate communities were altered under increasing nutrient concentrations.}

Biological communities are sensitive to changes in nutrient levels in streams, and the combination of different taxa can be a useful indicator of stream health. Assessing biological condition involves comparing the observed number of taxa at a site to the number of taxa expected based on a set of regional reference sites. A stream with a score greater than 80 percent implies an unaltered stream, whereas a stream with a score less than 80 percent implies an altered biological condition.

Algal and invertebrate community conditions decreased by about 30 percent as stream nutrient concentrations increased (fig. 1-1). Biological community conditions reflected regional reference conditions when nutrient concentrations were low. In the Columbia Plateau, Snake River, Ozarks and Georgia Coastal areas, many sites had algal and invertebrate communities similar to reference conditions (fig. 1-2). In comparison, altered biological community conditions occurred at most sites in the Central Nebraska, Upper Mississippi, White-Miami, and Delmarva areas where the nutrient levels were elevated. These areas also have the highest percentage of agricultural land use. Although many agencies use both algae and invertebrate communities in biological assessments, invertebrate communities tend to respond to a wider range of physical and chemical stressors, whereas algal communities respond directly to changes in nutrient concentrations.

\section{Stream habitat plays an important role in determining biological communities in agricultural streams.}

Stream habitat (for example, stream substrate, water temperature, and canopy cover) provides the physical "home" required by aquatic life. In this study, stream habitat exerted a

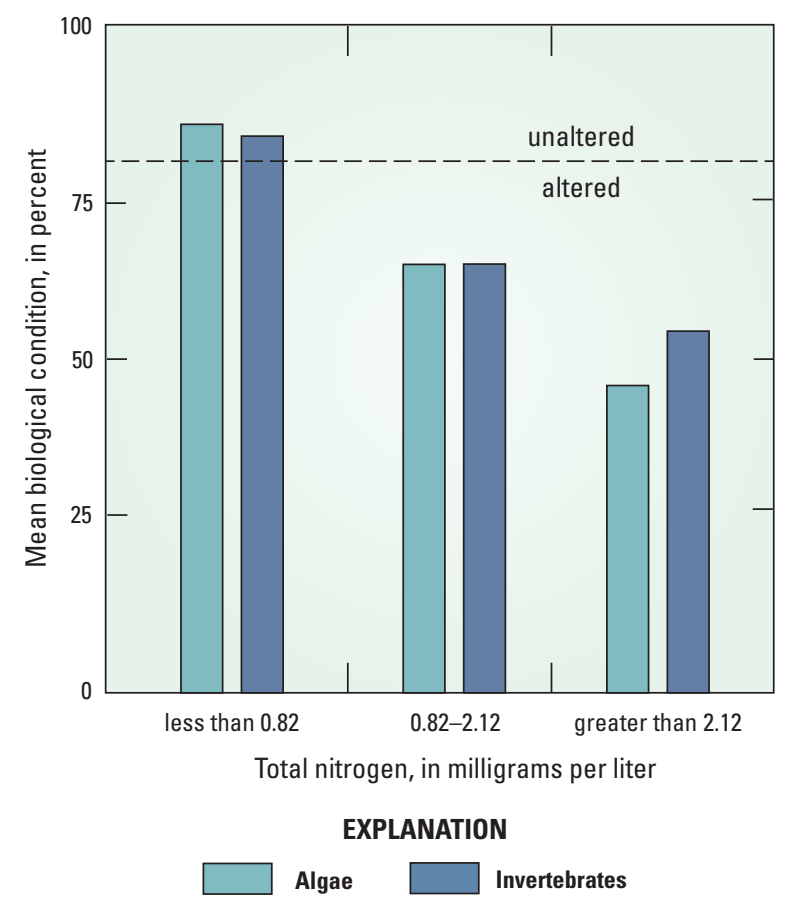

Figure 1-1. Algal and invertebrate community condition decreased with increasing concentrations of total nitrogen in agricultural streams across the United States (total phosphorus had a similar response). The three nutrient categories are based on the lower, middle, and upper one-third of the National WaterQuality Assessment (NAWQA) Project summer concentrations collected from 1992 to 2001 from surface-water sites in all land uses. Bars above dashed line infer biological communities similar to reference conditions, whereas bars below dashed line infer that sites differ from reference conditions.

stronger influence on invertebrate community condition than nutrient concentrations in six of the eight study areas. The proportion of fine-grained substrate and instream habitat cover were the most influential habitat variables, whereas stream discharge, suspended sediment, water depth, and canopy cover also were important. 


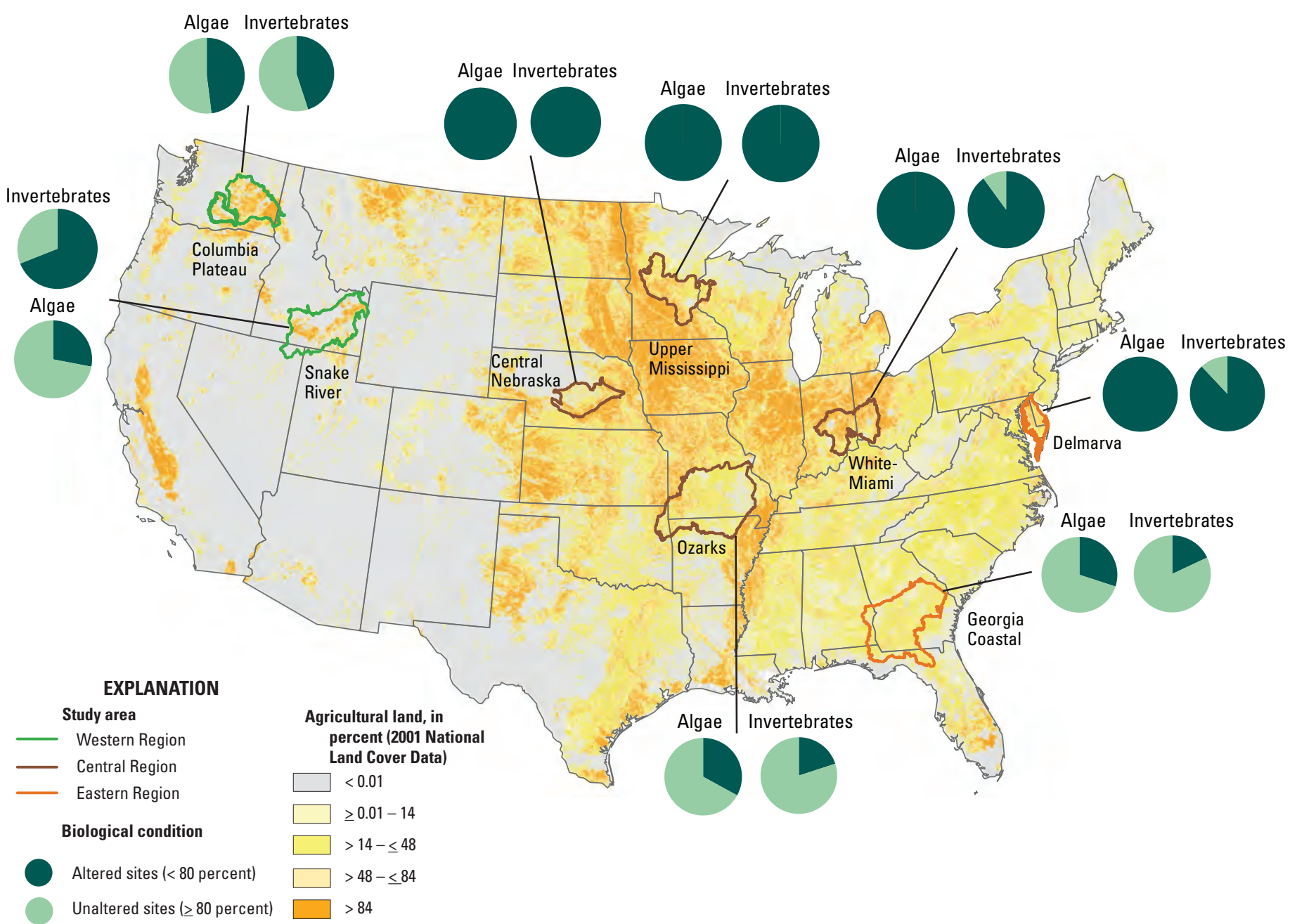

Figure 1-2. The most impaired streams, based on algae or invertebrate condition, were in those study areas with the greatest agricultural land use.

The Columbia Plateau was the only study area where invertebrate communities were more strongly related to the combination of nitrogen and phosphorus than to habitat (fig. 1-3). The Snake River represents a condition where habitat plays a more important role than nutrients. In contrast, invertebrate community condition in the White-Miami area was related to habitat, but not to nutrient concentrations. The high nutrient concentrations in this study area do influence biota, but because concentrations are constrained to a narrow range and well above levels required by aquatic biota, nutrients are not limiting.

\section{Limiting the amount of agricultural land along stream buffers can improve algal and invertebrate community condition.}

Biological condition rapidly decreased as agricultural land in the 100-meter stream riparian buffer increased to about 20 percent and then leveled off, suggesting there may be a point beyond which biological communities do not change (fig. 1-4). Streams with less than 20 percent agricultural land in the stream buffer had 22-28 percent higher invertebrate and algae community condition than streams with more agricultural land in the buffer. Three of the areas with some of the lowest stream concentrations of total nitrogen and total 


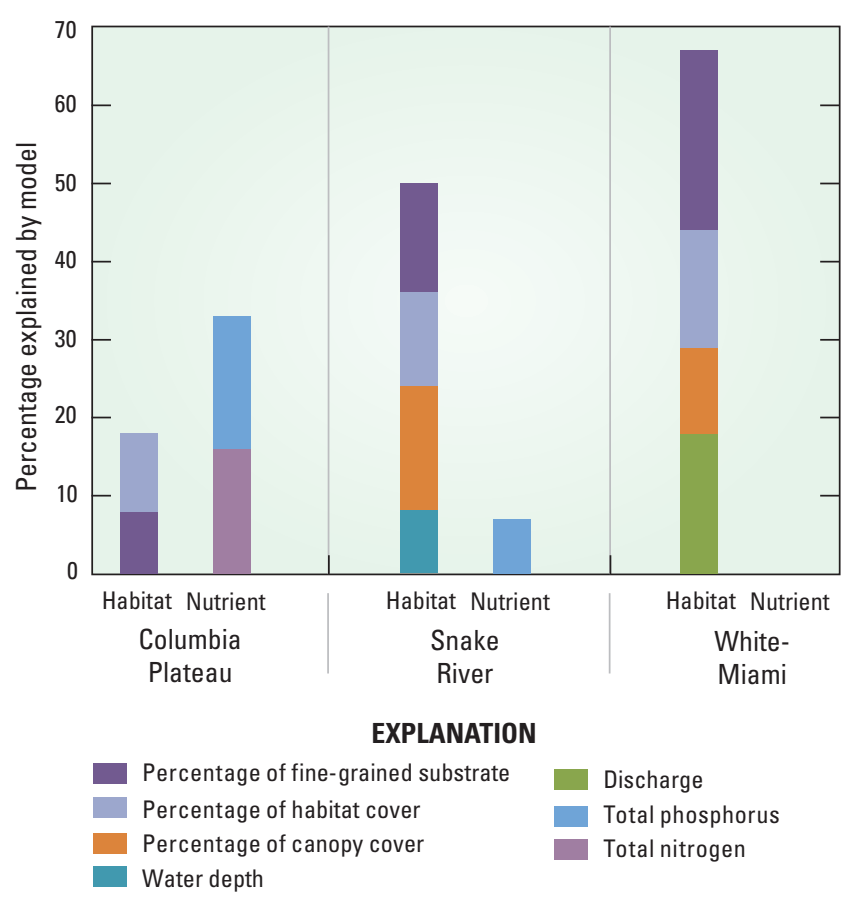

Figure 1-3. In the Columbia Plateau, nutrients accounted for a larger percentage of invertebrate community condition than habitat, whereas in the Snake River area habitat was more important than nutrients. In contrast, in the White-Miami nutrients did not explain any of the invertebrate condition; however, both nitrogen and phosphorus were well above biological requirements and therefore still influence the communities that are present in those streams.

phosphorus-Snake River, Ozarks, and Georgia Coastal—also had the least amount of agricultural land in the stream buffer, which further illustrates the importance of vegetated stream buffers in controlling nutrient transport and maintaining healthy biological communities.

\section{Elevated nutrient concentrations do not always result in nuisance levels of aquatic vegetation in agricultural streams.}

Aquatic vegetation provides critical habitat and food for invertebrates and fish. Excessive amounts of nutrients can result in nuisance levels of aquatic vegetation causing diminished dissolved oxygen levels, impaired recreational uses, and adverse effects to fish habitat and stream health. Nutrient levels were greater than U.S. Environmental Protection Agency (EPA) recommended regional levels in more than 70 percent of the streams assessed, yet benchmarks for algal biomass, percentage of macrophyte cover, and minimum daily dissolved oxygen levels were each exceeded

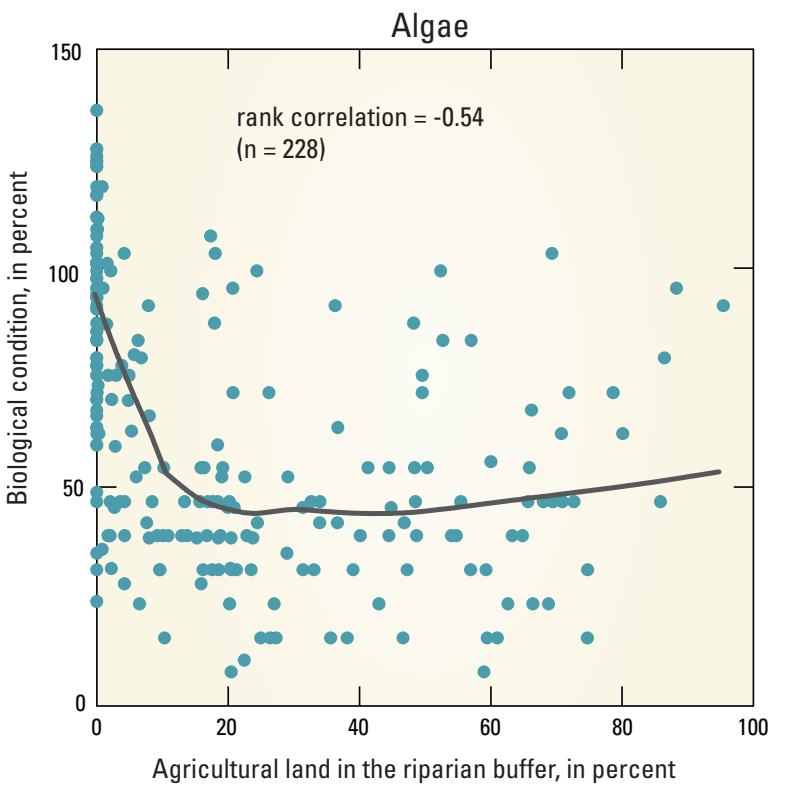

Figure 1-4. A relatively small amount of agricultural activity in the stream riparian area can have negative effects on the biological condition of algae. Streams with extensive riparian buffers tend to have high biological condition, whereas streams lacking riparian buffers tend to have low biological condition.

in less than 15 percent of streams assessed. The lack of a consistent response between increased nutrient levels and aquatic vegetation in streams is related to interactions of streamflow, light conditions, water temperature, and grazing by invertebrates and fish.

The nutrient-algal biomass model (Munn and others, 2010) provides a conceptual framework for understanding the complex interactions of nutrients, benthic algal biomass, and stream habitat (fig. 1-5). In the Delmarva study area, algal biomass generally increased as total phosphorus levels increased, following a linear response (fig. 1-5A). Increasing levels of total phosphorus in the Georgia Coastal study area did not result in an increase in algal biomass. A lack of increased algal biomass likely is due to the extensive riparian-forested wetlands along these streams, which reduces light penetration to the stream and acts as a filtering system reducing nutrients, both of which limit algal biomass (fig. 1-5B). In the White-Miami study area, there is no relation between total phosphorus levels and algal biomass because the total phosphorus levels exceed what is required for algal growth (fig. 1-5C). 

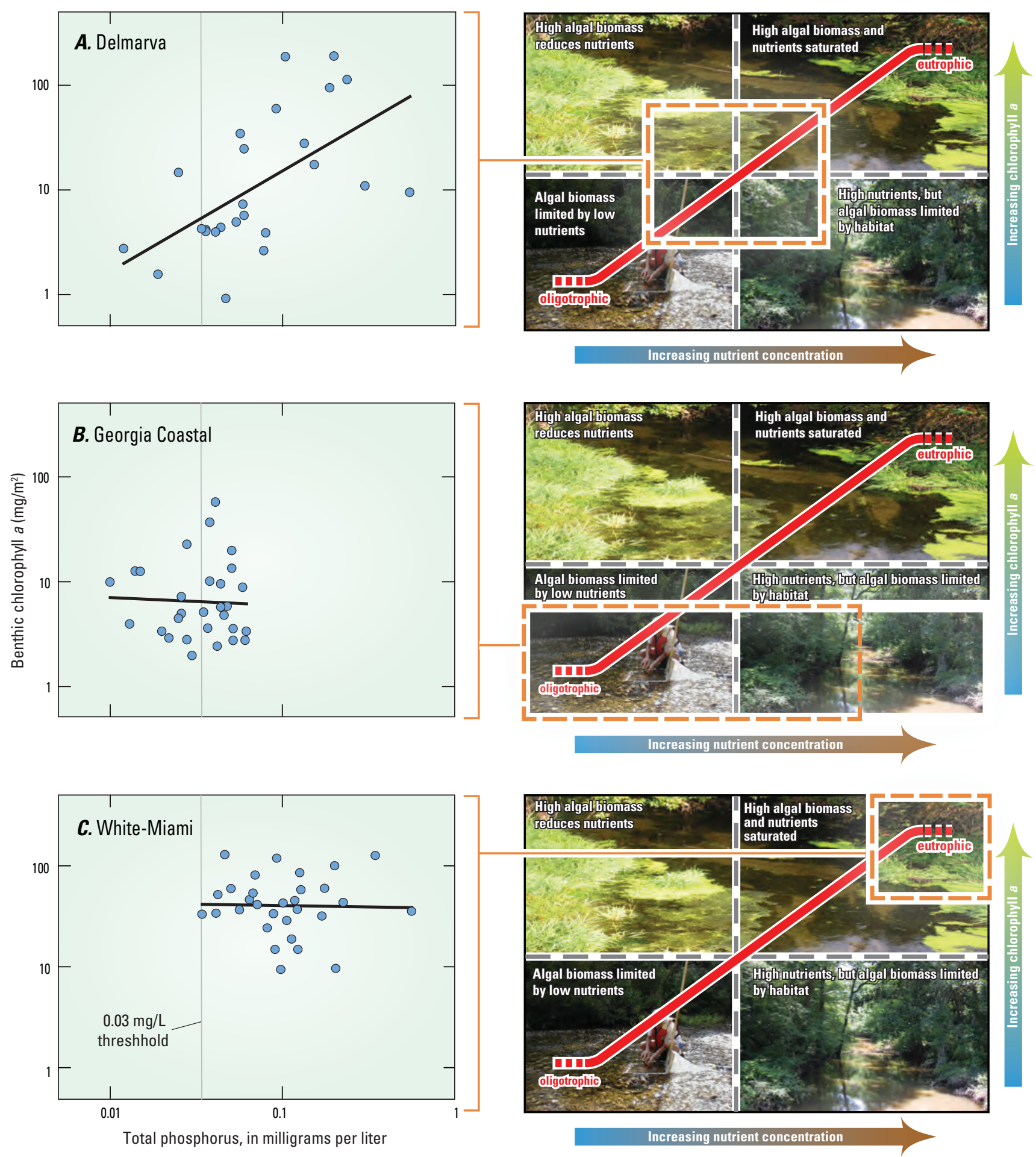

Figure 1-5. Elevated nutrient concentrations do not always result in nuisance levels of algae. The Nutrient-Algal Biomass Conceptual Model (Munn and others, 2010) illustrates that under certain conditions, increasing nutrient concentrations result in high amounts of benthic algae. However, large amounts of algae can deplete nutrients from the water column altering this relation (upper left quadrant). Alternatively, the physical characteristics of streams (habitat), such as the amount of shading from trees, may prevent the growth of algae resulting in elevated nutrient concentrations (lower right quadrant). A. Delmarva sites demonstrate a relatively common relation between total phosphorus and algal biomass. B. Georgia Coastal sites illustrate lower levels of algal biomass due to habitat limitation (primarily canopy shading and suspended sediment). C. White-Miami sites illustrate an area where total phosphorus concentrations are high at most sites and are above levels required by algae. 
Natural loss of nitrogen in streams is diminished by agricultural practices that decrease the amount of time water is temporarily stored within the stream channel or adjacent bank or bed sediments.

Nutrient removal processes (such as biological uptake and denitrification) in streams are often enhanced when water is in contact with streambed and stream-bank sediments. Agricultural practices that promote drainage - such as dredging and straightening of stream channels to move water more rapidly downstream - decrease the amount of time water is in contact with streambed and streambank sediments, thereby diminishing the natural capacity of many streams to remove nutrients such as nitrogen.

Model estimates indicate that nitrate in many of the agricultural streams in this study spends less than 1 percent of its time in storage within streambed and streambank sediments (fig. 1-6). In comparison, the average water storage within streambed and stream-bank sediments in many natural streams is about 16 percent (fig. 1-6). When a stream's natural ability to remove nutrients is reduced, more nutrients are transported to downstream receiving waters.

\section{Advances in modeling improve our understanding of how invertebrate communities respond to interactions of land use, habitat, and nutrients.}

An innovative modeling approach (Structural Equation Modeling) was used to provide insights into the connections between land use, stream buffer, instream habitat, and nutrients and how these interactions influence invertebrate communities. The amount of cropland in a watershed was the strongest predictor of both particulate-bound chemicals (a composite of total phosphorus, suspended sediment, and particulate carbon) and dissolved chemicals (a composite of inorganic nitrogen and conductivity) in streams, both of which can decrease invertebrate community condition. Forested wetlands in the riparian buffer sometimes reduced this effect due to their capacity for filtering out sediment and the biological uptake of nutrients prior to water entering the stream. For example, croplands in the Eastern Region were associated with increased dissolved chemicals in streams; however, concentrations were not sufficiently high to alter invertebrate condition, likely due to extensive forested wetland in riparian buffer. Furthermore, although particulate-bound chemicals did have a negative influence on invertebrate community condition, forested wetland in riparian buffer also had a negative influence on the levels of particulate-bound chemicals, helping to ameliorate potential adverse effects (fig. 1-7).
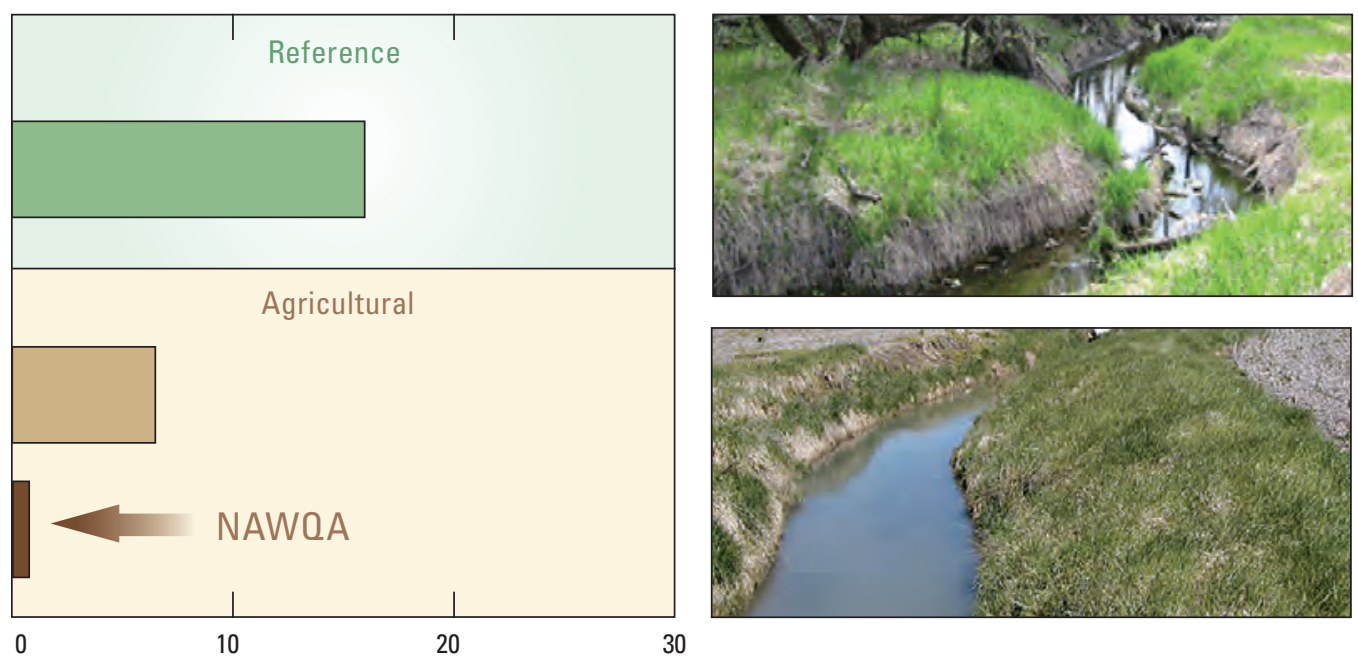

Average transient storage $\left(\mathrm{F}_{\text {med }}\right)$, as a percent of time water is in storage

Figure 1-6. Stream water in the studied agricultural watersheds has little contact time with sediments in the streambed and streambank, which limits the natural removal of nutrients from the water. Transient storage - the temporary retention of water either within the stream channel or adjacent bank or bed sediments-is low in the agricultural streams examined in this study compared to other agricultural and reference streams for multiple studies (Mulholland and others, 2008; Sheibley and others, 2014). Low transient storage results in little contact time between stream water and bank and bed sediments, diminishing both denitrification and the uptake of nitrate. Consequently, more nitrate will be exported downstream. 
Eastern Region agricultural streams

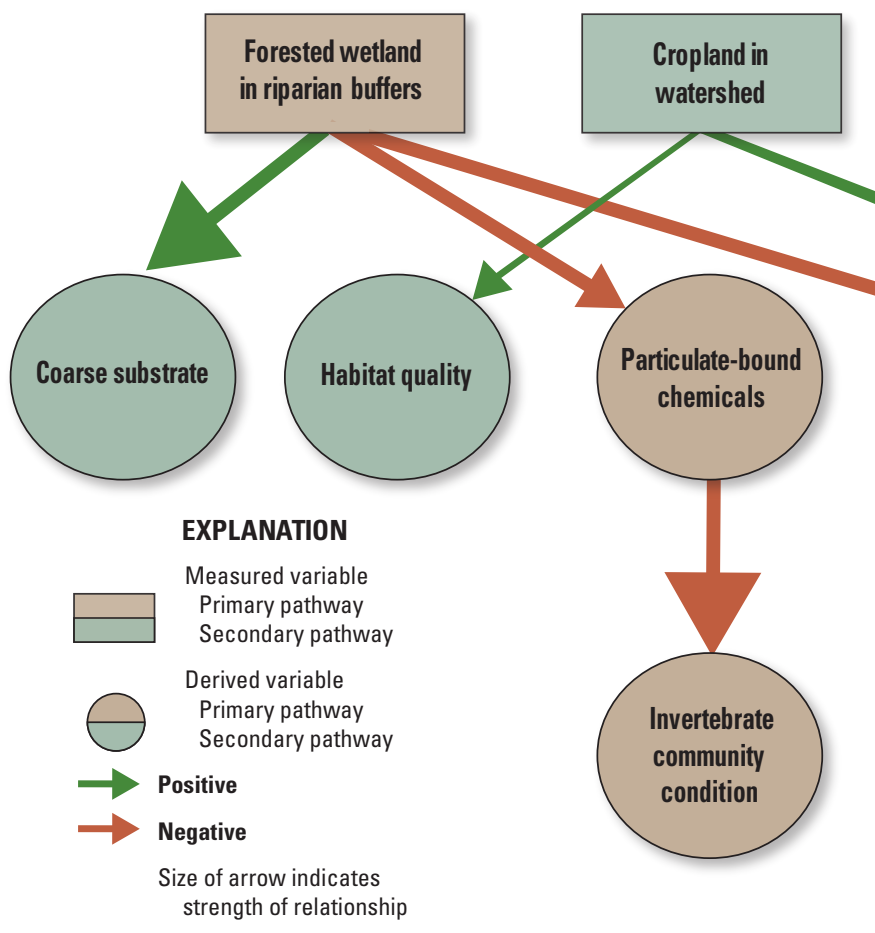

Increased cropland was also related to an increase in nutrients in the Central and Western Regions, which resulted in a decrease in invertebrate condition. In the Western Region, cropland in the watershed increased dissolved chemicals, which decreased invertebrate community condition. In contrast, in the Central Region, cropland increased both particulate and dissolved nutrients, but only particulate-bound chemicals negatively influenced invertebrate community condition. Although riparian buffers are present in the Central and Western Regions, the model simulation results indicate they are insufficient at a regional scale to influence invertebrate community condition. This is particularly true in some areas like the White-Miami where many agricultural fields have been tile drained and therefore nutrients can bypass the stream buffer. This finding suggests that stream buffers can have an important role in reducing the transport of nutrients to surface waters to protect the health of biological communities.

\section{Implications for Management of Agricultural Streams}

Algal and invertebrate communities were altered under increasing nutrient concentrations, negatively influencing biological condition in streams. Managers should consider strategies that take advantage of the wide variety of tools available to reduce nutrient inputs to streams. Furthermore, multiple taxonomic groups (i.e., algae, invertebrates) should be used in stream assessments because assessments that rely on a single biological community may not accurately reflect the health of a stream. (chapter 6)
Figure 1-7. Biological communities respond to a complex interaction of land use, habitat, and nutrients. A Structural Equation Model based on sites in the Eastern Region estimated that increased cropland was associated with an increase in dissolved chemicals; however, forested riparian buffers reduced the influence of cropland on invertebrate community condition by removing sediment and nutrients prior to water entering the stream.
Elevated nutrient concentrations do not always result in nuisance levels of aquatic vegetation in agricultural streams; therefore biological assessments are necessary to correctly identify the overall condition of a stream. While streams with elevated nutrient concentrations may not reflect local biological impairment, they can still be an important source of nutrients to downstream receiving waters. (chapter 5)

Stream habitat plays an important role in determining biological communities in agricultural streams; therefore, it is important to include stream habitat assessments in nutrient programs to determine the relative influence of habitat and nutrients on biological conditions. (chapter 6)

Limiting the amount of agricultural land along stream buffers can improve algal and invertebrate community condition; therefore, maintaining or improving riparian buffers is an important tool that managers can use for enhancing agricultural streams. (chapter 6)

Natural loss of nitrogen in streams is diminished by agricultural practices; therefore enhancing the ability of an agricultural stream to naturally transform nutrients should be part of any nutrient management strategy. Increasing natural loss of nitrogen can be done by protecting or restoring the physical complexity of a stream, which will benefit the local stream health, as well as downstream receiving waters impacted by nutrient loading. (chapter 4)

Complex modeling improves our understanding of regional differences in how invertebrate communities respond to interactions of land use, habitat, and nutrients. Tools like Structural Equation Modeling provide insight into the factors most likely influencing the biological condition of streams, and hence can help optimize management strategies for specific regions. (chapter 6) 


\section{Introduction}

Nutrients—primarily nitrogen and phosphorus—are chemical compounds essential for sustaining plant and animal life. The natural global nitrogen cycle has been extensively altered through production and application of nitrogen fertilizers, cultivation of nitrogen-fixing crops, animal waste disposal, wastewater and industrial discharges, and combustion of fossil fuels (Galloway and others, 1995; Vitousek and others, 1997). These human alterations have approximately doubled the rate of nitrogen inputs into the terrestrial nitrogen cycle and have greatly increased the transfer of nitrogen from rivers to estuaries and other sensitive receiving waters. Human activities also have profoundly influenced the cycling of phosphorus through the environment, doubling the rate of phosphorus delivery from land to the oceans (Howarth and others, 2000). Elevated nutrient concentrations can create a variety of problems including impacts to aquatic biota, water treatment, recreational activities, and human health. The dominant concerns for excess nutrients in streams includes (1) nuisance levels of aquatic vegetation; (2) decreased oxygen levels in streams, reservoirs, and coastal estuaries; (3) toxic algal blooms; (4) loss in habitat; and (5) shifts in aquatic food webs.

Many factors affect the transport and concentrations of nutrients in streams and groundwater, including the timing, intensity, and distribution of nutrient inputs; land management practices and other human activities; natural factors, such as soil and aquifer characteristics; and physical, chemical, and biological processes in streams. This primer presents some of the basic elements of the four key components of understanding the effects of nutrients in agricultural landscapes on aquatic life in streams: (1) sources and forms of nutrients, (2) transport to streams and groundwater, (3) nutrient transformations, and (4) biological response to nutrients.

\section{Nutrient Sources and Forms}

Nutrients are necessary in the formation of all biological life and therefore are an essential part of a healthy ecosystem. Although there are many types of nutrients, nitrogen and phosphorus are the primary essential nutrients in freshwater ecosystems. Nitrogen and phosphorus are required for development of cellular and genetic material. Nitrogen is used in the formation of all amino acids and nucleic acids (deoxyribonucleic acid [DNA] and ribonucleic acid [RNA]), whereas phosphorus is an essential element in the energy molecules (adenosine diphosphate [ADP], adenosine triphosphate [ATP], nicotinamide adenine dinucleotide phosphate [NADP]), as well as the nucleic acids.

Natural sources of nutrients include nitrogen gas, which constitutes 78 percent of the Earth's atmosphere; however, most plants and animals cannot use it directly and must rely on processes that convert nitrogen gas into usable forms. For example, nitrogen "fixing" organisms, including specific bacteria and algae (for example, blue-green algae, also referred to as cyanobacteria), can convert nitrogen gas into biologically useable forms, such as ammonium and nitrate. Phosphorus also occurs naturally in large part as phosphate minerals in sediment and rocks.

Anthropogenic sources of nutrients include point and nonpoint sources. Point sources include wastewater treatment or industrial discharges, whereas nonpoint sources include fertilizer application, manure from livestock, and atmospheric deposition. The diverse nature of nonpoint source pathways to streams and groundwater make it more difficult to manage and remediate compared to point sources. About 90 percent of nitrogen and 75 percent of phosphorus released to the environment originate from nonpoint sources; the remaining percentages are from point sources (Puckett, 1995). The use of nitrogen and phosphorus fertilizers has increased 10-fold and
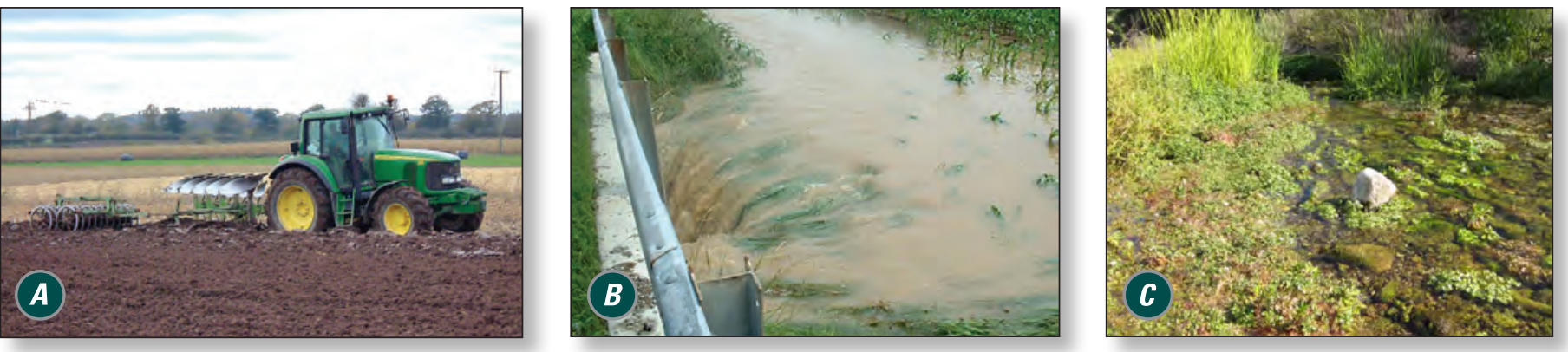

Farming in lowa $(A)$, agricultural runoff $(B)$, and algal growth in agricultural stream $(C)$. Photographs by $A$, Lynn Betts, U.S. Department of Agriculture, Natural Resources Conservation Service; B, John Wilson, U.S. Geological Survey, 2003; C, Mark Nardi, U.S. Geological Survey, May 3, 2012. 
4-fold, respectively, between about 1950 and the early 1980s (fig. 2-1). Since about 1980, applications of nitrogen and phosphorus fertilizers within the United States have remained relatively stable. This stability is in large part because of increasing fertilizer costs, growing environmental concerns, and changing agricultural and waste management practices, which have reversed or slowed the pace of the increased use. Nationally, synthetic fertilizer use in agricultural areas remains the largest single nonpoint source of nutrients (fig. 2-2). More than 10 million tons of nitrogen and nearly 2 million tons of phosphorus are applied each year as commercial fertilizer. Most of the applications are for agricultural purposes, although a small amount, about 2-4 percent, of the total nitrogen fertilizer, is used in nonagricultural settings such as city parks and residential lawns.

Nutrients occur in both dissolved and particulate forms, but the dissolved forms are the most readily used by plants and easily transported to streams and groundwater. Nutrients also consist of both organic (contain carbon) and inorganic (no carbon) forms. Aquatic vegetation, bacteria, and fungi use the dissolved forms of inorganic nitrogen, which consists of

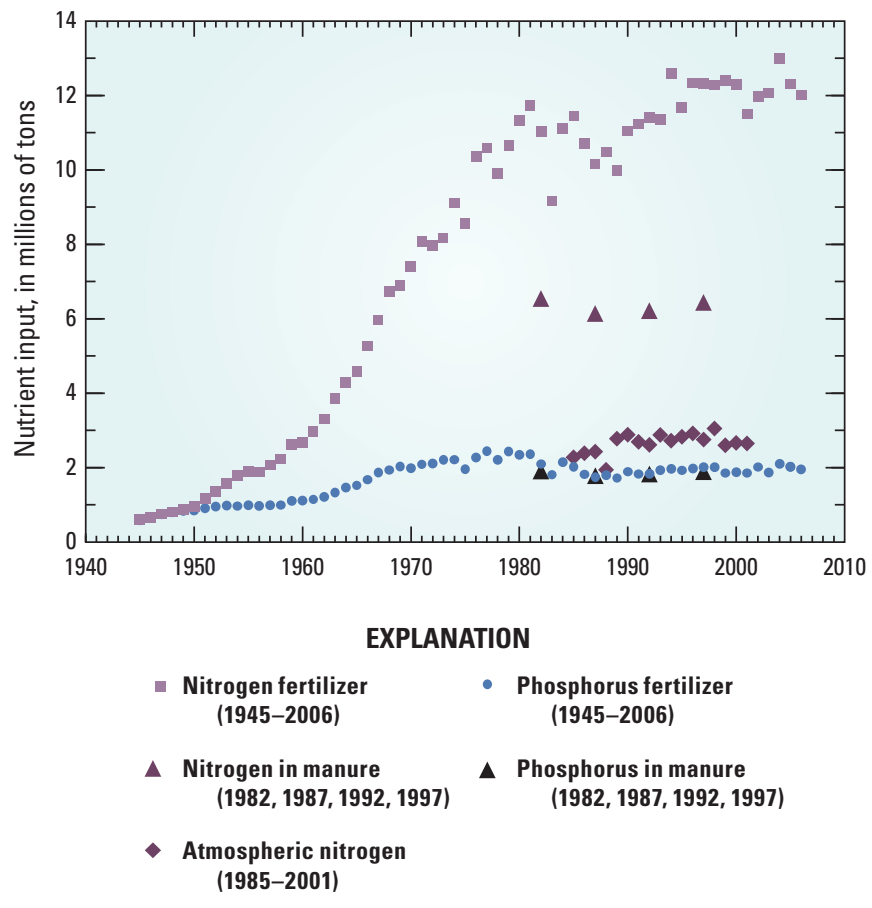

Figure 2-1. The use of nitrogen and phosphorus fertilizers have increased 10-fold and 4-fold, respectively, between about 1950 and the early 1980s (modified from Ruddy and others, 2006).

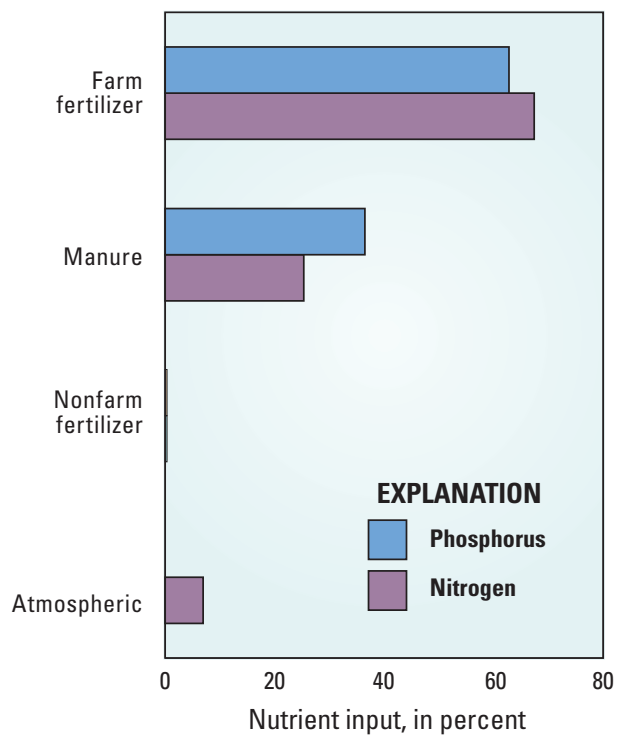

Data on atmospheric phosphorus inputs not available.

Figure 2-2. Farm fertilizer is the dominant source of nitrogen and phosphorus in agricultural lands (Dubrovsky and others, 2010).

ammonium, nitrate, and nitrite. Nitrate is the primary form in streams and shallow groundwater. Phosphorus also occurs in organic and inorganic forms with plants and microbes using the dissolved inorganic form, primarily orthophosphate.

Five measures of nitrogen- and phosphorus-containing nutrients are commonly addressed in nutrient studies. All forms of nutrients discussed in this report are expressed as concentrations of nitrogen or phosphorus. For example, a nitrate concentration of $10 \mathrm{mg} / \mathrm{L}$ refers to a nitrate concentration of $10 \mathrm{mg} / \mathrm{L}$ as nitrogen. Dissolved inorganic nitrogen (DIN) is used in some places in this report and refers to the combination of nitrate, nitrite, and ammonia.

Total nitrogen includes nitrogen in all its forms-nitrate, nitrite, ammonia, and organic nitrogen. Nitrite generally is unstable in surface water and contributes little to the total concentration of nitrogen in water. Organic nitrogen (mostly from plant material or organic matter) can exist in considerable proportions and contribute substantially to concentrations of total nitrogen in streams. 
Nitrate, a compound of nitrogen and oxygen, is the primary form of dissolved nitrogen in streams and groundwater. Nitrate is one of the dominant forms of nitrogen readily used by aquatic vegetation.

Ammonia, a compound of nitrogen and hydrogen, is a dissolved form of nitrogen that typically occurs in lower concentrations than nitrate except below specific point sources. As measured by the USGS National Water-Quality Laboratory, total ammonia includes ammonium ion and un-ionized ammonia. Un-ionized ammonia typically is a minor component of ammonia at $\mathrm{pH}$ (acidity) levels commonly observed in streams and groundwater. Ammonia is readily used by aquatic vegetation, but also is toxic to invertebrates and fish at high concentrations.

Total phosphorus consists of dissolved (inorganic and organic) and particulate (inorganic and organic) phosphorus, and is the most common form measured in surface waters. Phosphate, compounds of phosphorus, oxygen, and hydrogen, typically constitute most of the dissolved phosphorus in natural water, and are referred to as orthophosphate. Orthophosphate can be readily used by aquatic vegetation.

\section{Transport of Nutrients}

Nutrient transport depends on the chemical makeup of the nutrients themselves, which affects mobility and persistence. Some compounds, such as nitrate, are soluble and move with water to streams and groundwater. In contrast, most forms of phosphorus are not soluble. Rather, these compounds attach to soil particles and are often transported to streams with eroded soil, particularly during times of high runoff from precipitation or irrigation. Groundwater typically is less vulnerable to contamination by compounds that attach to soils, such as phosphorus. Natural and human factors determine the transport of nutrients to streams and groundwater (fig. 2-3). Key natural factors, including soil type, geology, precipitation, temperature, and slope of the land can govern the amount and timing of transport of nutrients. Transport also is affected by agricultural practices, such as water withdrawal and artificial drainage as well as best management practices (BMP). These factors can result in varying concentrations of nutrients in streams and groundwater, even in watersheds that may have similar land-use settings and rates of fertilizer use.

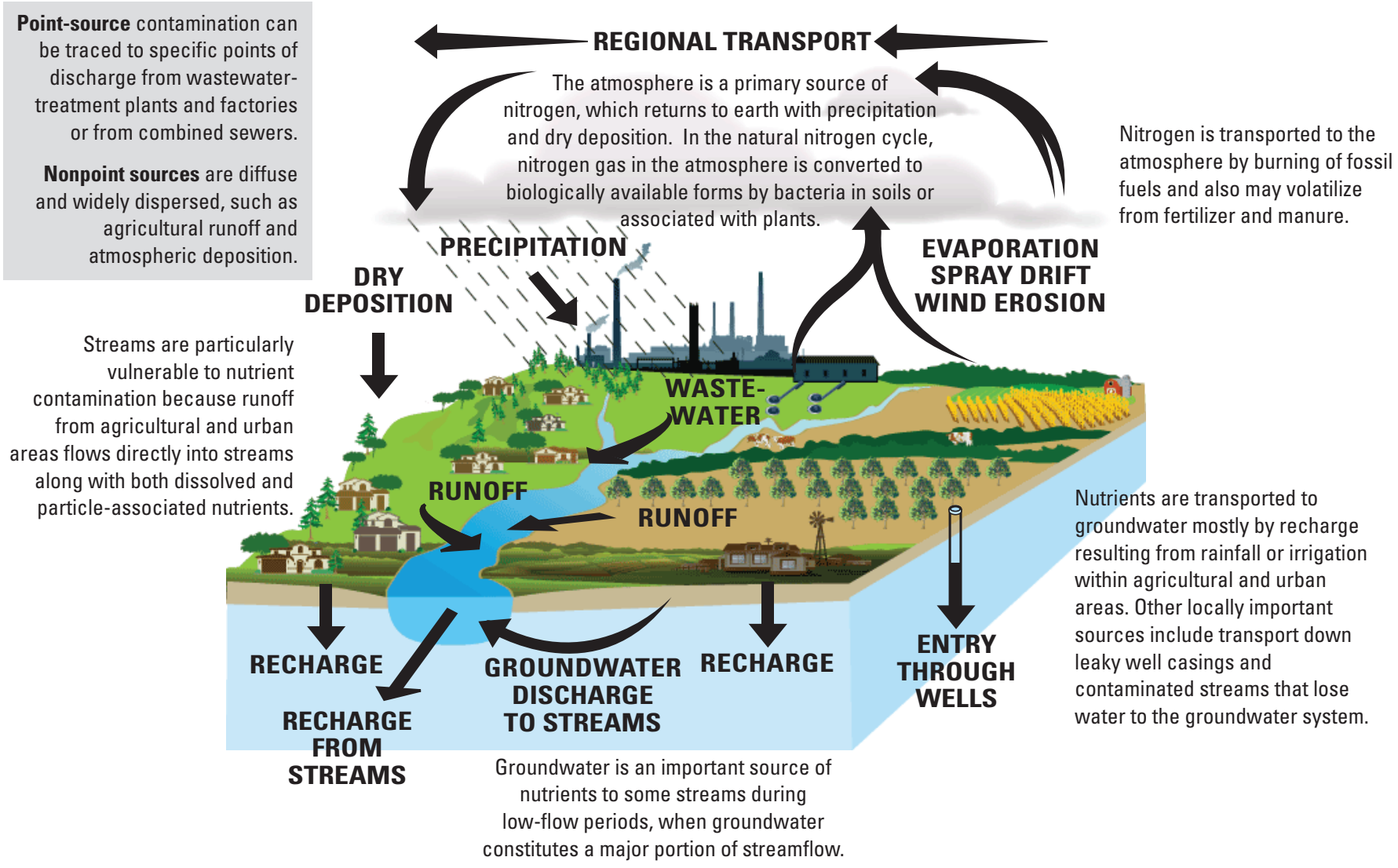

Figure 2-3. Nutrients from nonpoint and point sources are cycled throughout the hydrologic system, and are affected by chemical, physical, and biological processes in different parts of the system. (Modified from Majewski and Capel, 1995.) 
Watershed hydrology influences how nutrients are transported to streams. In agricultural landscapes, the transport of nutrients to streams is driven by precipitation or irrigation. The timing and intensity of precipitation and fertilizer and manure applications greatly affect the amounts of nutrients in the associated runoff and drainage. Additionally, a multitude of natural and human factors affect water entering streams from land-surface runoff and groundwater. High rainfall, snowmelt, and (or) excessive irrigation, especially following recent fertilizer applications, can accelerate transport of nutrients to streams. Watersheds with steep slopes and sparse vegetation generally are vulnerable to nutrient transport to streams by runoff. Clay-rich and compacted soils or soils underlain by impermeable layers can create relatively quick runoff. Artificial tile drains and ditches also provide quick transport of nutrients to streams.

In contrast to streams, only dissolved forms of nutrients move substantial distances in groundwater. Similar to streams, the transport of nutrients to groundwater is driven by the amount and timing of precipitation or irrigation, which results in groundwater recharge. Nitrate is soluble and moves readily with water, and is the dominant nutrient species in groundwater. Phosphorus attaches to particles and is largely retained by the soil and aquifer materials. In addition, transport of nutrients to and within groundwater systems is much less predictable than transport of nutrients in streams because flow is considerably slower and more complex than the flow of stream water. Nitrate is readily transported to shallow groundwater in well-drained areas with rapid infiltration and highly permeable subsurface materials.
Crop-management practices commonly designed to decrease or slow the movement of water, sediment, and nutrients to streams also can increase infiltration of water and nutrients into the ground.

\section{Nutrient Transformations}

Natural streams remove nutrients from the water column due to biological uptake (algae and aquatic plants) and microbial transformations. Headwater streams are particularly important in this process, both because they dominate the total stream miles in a watershed, and because their high land surface to water volume ratio is conductive to nutrient uptake and transformation. Therefore, headwater streams play a critical role in controlling the export of nutrients to downstream waters (Peterson and others, 2001). In contrast, large rivers tend to act as transport systems moving nutrients to downstream receiving waters.

The form of nitrogen and its subsequent transformations greatly affect how it is transported and the potential environmental impact. Land-surface runoff of nitrogen in agricultural lands is largely in the form of nitrate (95 to greater than 99 percent), which is mobile and easily transported in water and unlike ammonium, which binds to soils and streambed sediments (Triska and others, 1993).

Nitrate can be retained in or removed from streams by two dominant transformations - uptake by aquatic vegetation and denitrification (fig. 2-4). Nitrate dissolved in surface water or groundwater can be used for growth by aquatic

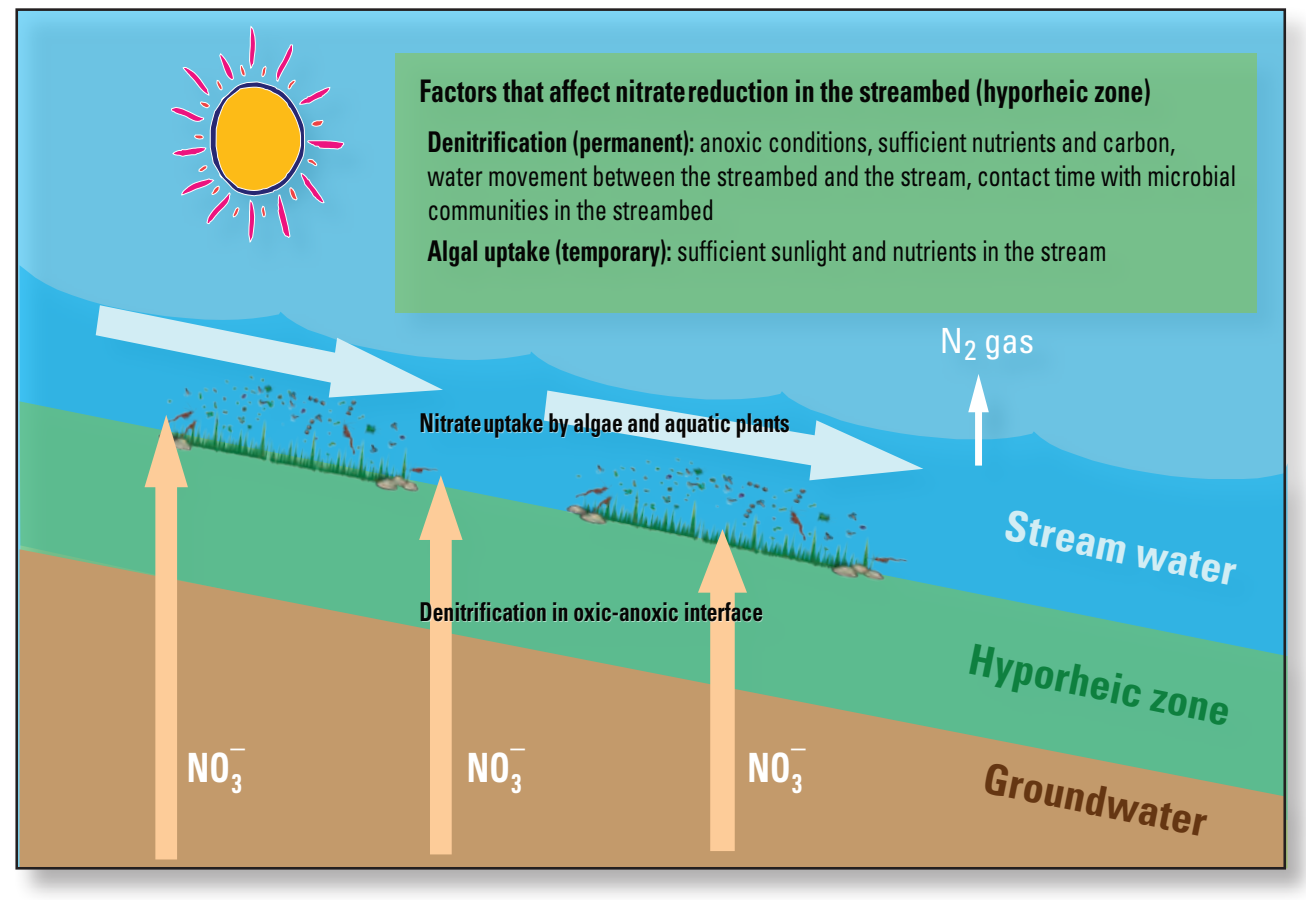

Figure 2-4. Conceptual diagram showing how nitrate $\left(\mathrm{NO}_{3}^{-}\right)$is substantially reduced in the hyporheic zone through denitrification in some stream systems or on the streambed due to biological uptake by aquatic vegetation. 
vegetation suspended in the water column or attached to the streambed. Nitrate uptake during photosynthesis temporarily removes nitrogen from the water by incorporating it into aquatic vegetation. Later, when aquatic vegetation decomposes, nitrogen is returned to the water, in the form of dissolved organic nitrogen or ammonium. Ammonium is the form preferred by aquatic vegetation but it also is readily transformed to nitrate by nitrifying bacteria when oxygen is present.

Denitrification by microbial communities is the transformation of nitrate to nitrogen gas $\left(\mathrm{N}_{2}\right)$ that occurs when dissolved oxygen concentrations are low and permanently removes nitrogen from the water. During the decomposition of organic matter, bacteria use organic carbon and oxygen in the nitrate molecule to form carbon dioxide and $\mathrm{N}_{2}$ gases in the streambed or "hyporheic zone." Depending on the amount of respiration and decomposition in the hyporheic zone, an anoxic zone (where no oxygen is present) may form below the streambed (fig. 2-4). The source of organic carbon in streambed sediment typically is surface water that moves dissolved organic carbon down into the streambed, or deposition of coarse and fine particulate organic matter.

Although nitrogen is removed from streams by biological uptake and microbial activity, phosphorus removal is dominated by biological uptake, sorption to particle surfaces, and burial in the streambed. The biologically available form of phosphorus is dissolved orthophosphate, which is readily taken up by microbes, algae, and aquatic plants where it is then converted into biological tissue. Upon decomposition, dissolved and particulate organic phosphorus are released into the water, where they are transformed into inorganic forms, such as orthophosphate. Although biological processes like these are a major part of phosphorus cycling in streams, physical-chemical transformations also influence biological availability. This physical-chemical process is referred to as the sorption-desorption reaction, in which various forms of phosphorus are either bound or released from minerals (for example, iron oxides) or organic particles. The degree of binding depends on the phosphorus concentrations, forms of phosphorus, $\mathrm{pH}$, and dissolved-oxygen concentrations. Sorption of phosphorus can result in removal of dissolved phosphorus from the water and storage in sediments for biological use at a later time when conditions permit such as during resuspension during storms or in anoxic conditions, which release orthophosphate. Phosphorus typically occurs at lower concentrations in natural streams than nitrogen because phosphate-rich minerals and rocks are not widespread, and the phosphorus tends to bind to soils and sediment.

\section{Stream Aquatic Life and Effects of Nutrients}

There are approximately 5 million $\mathrm{km}$ of streams and rivers in the contiguous United States with the majority consisting of small streams that serve as an important connection of land use to downstream receiving waters. These streams contain a diversity of aquatic species that sustains critical services for the environment and human uses. Aquatic life in streams consists of microbes, aquatic vegetation (algae and aquatic plants), invertebrates, and fish, all of which play key roles in structuring the food web that sustains aquatic life, wildlife, and in some cases humans (fig. 2-5).

Microbes - bacteria and fungi - play a key role in decomposing and processing dead organic material to sustain their growth, and convert organic material to forms more usable for plants and animals in the food web. Microbes also play a key role in the transformation of nitrogen into various forms.

Aquatic vegetation is a general term that includes algae and aquatic plants, both of which are photosynthetic and therefore utilize sunlight and nutrients to produce organic material for growth. This makes aquatic vegetation the primary producers that, along with microbes and fungi, provide the base of the food web for stream ecosystems. Aquatic plants are "true" plants because they contain a vascular system and flowers. In contrast, algae are plantlike organisms that range in size from single cells to large filamentous forms. Algae generally are the dominant primary producers in streams and respond rapidly to changes in the environment because of their short life span (days to weeks) and rapid growth rates. Algae in streams are dominated by benthic forms, which reside on the stream bottom attached to hard surfaces (for example, rocks) or on fine-grained sediments (for example, sand). Some algae live in the water column and are referred to as seston. The most common forms of algae in streams include green algae (Chlorophyta), diatoms (Bacillariophyta), and blue-greens (Cyanophyta, also classified as the bacteria, Cyanobacteria). Aquatic plants are more common in wetlands and shallow lakes, but can be present in substantial amounts in streams and the margins of larger rivers. Macrophytes refer to large forms of filamentous algae (commonly Cladophora) and aquatic plants. 


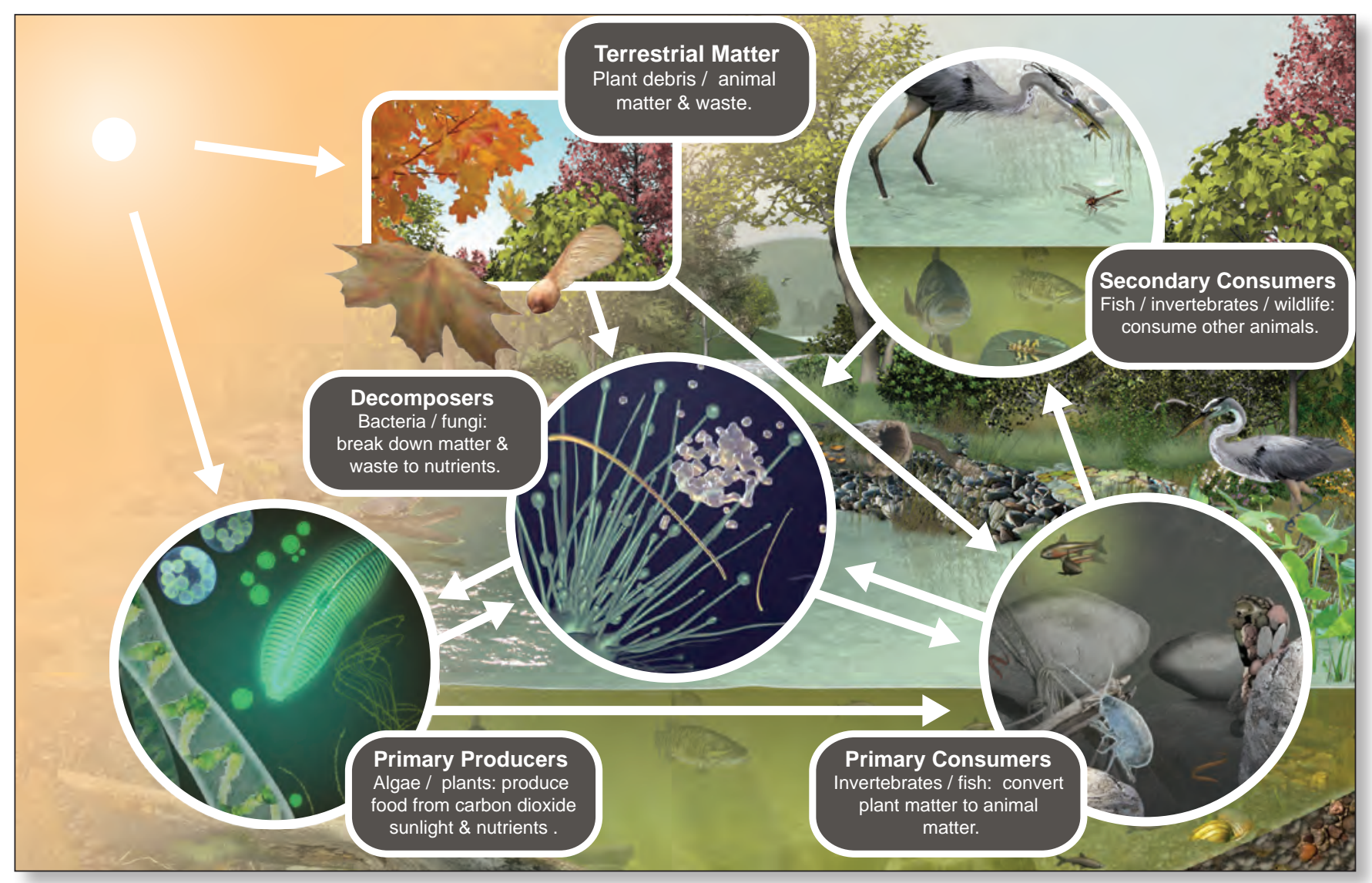

Figure 2-5. A simplified food web in a stream ecosystem shows the interaction between energy coming from the sun and the biota, which include primary producers (algae and aquatic plants), primary consumers (caddisflies, amphipods, and minnows), secondary consumers (herons, bass, dragonflies, and stoneflies), and decomposers (bacteria and fungi). (Illustration by Frank Ippolito, Production Post Studios, 110 North Fulton St., Bloomfield, N.J.)
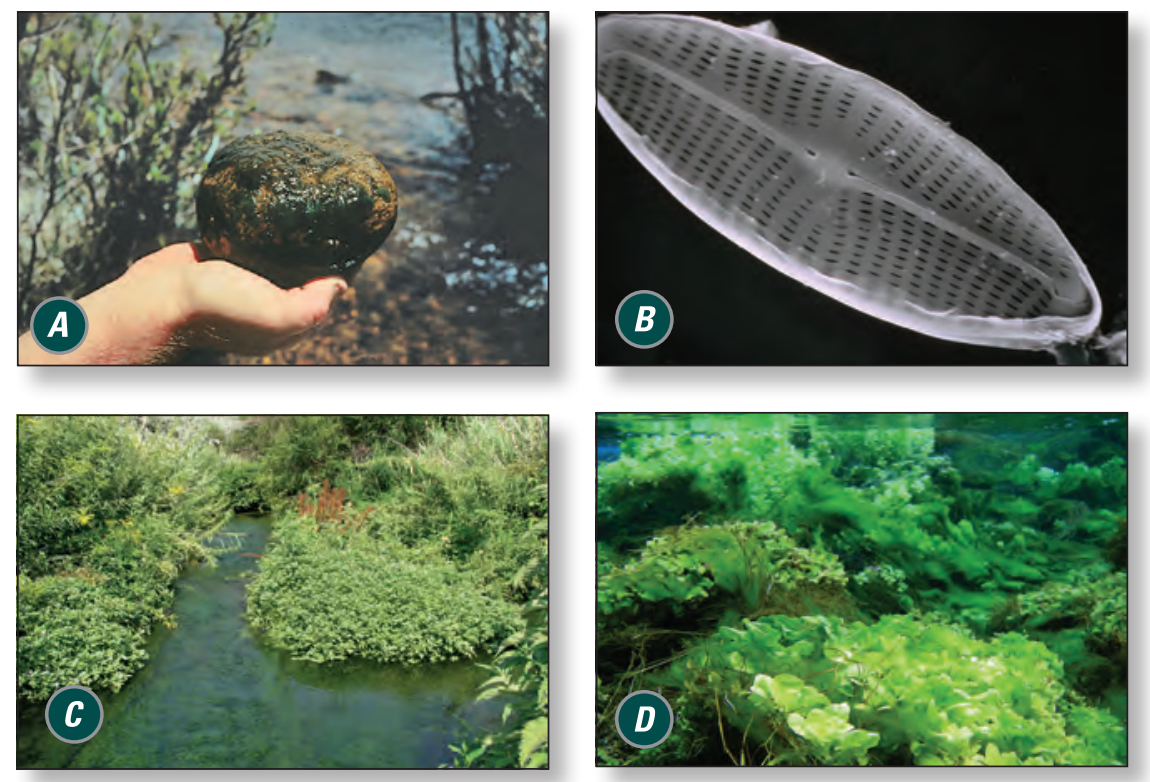

Benthic algae and aquatic plants are found in many forms. Photograph $A$, algae on rock, M.D. Munn, U.S. Geological Survey, May 4, 2006; $B$, diatom, Philadelphia Academy of Sciences, May 4, 2006; $C$, aquatic plants, Blind Canyon Spring near Sendell, Idaho, Christopher Mebane, U.S. Geological Survey, March 29, 2012; D, submerged aquatic plants, Blue Lake Springs near Twin Falls, Idaho, Christopher Mebane, U.S. Geological Survey, March 10, 2008. 


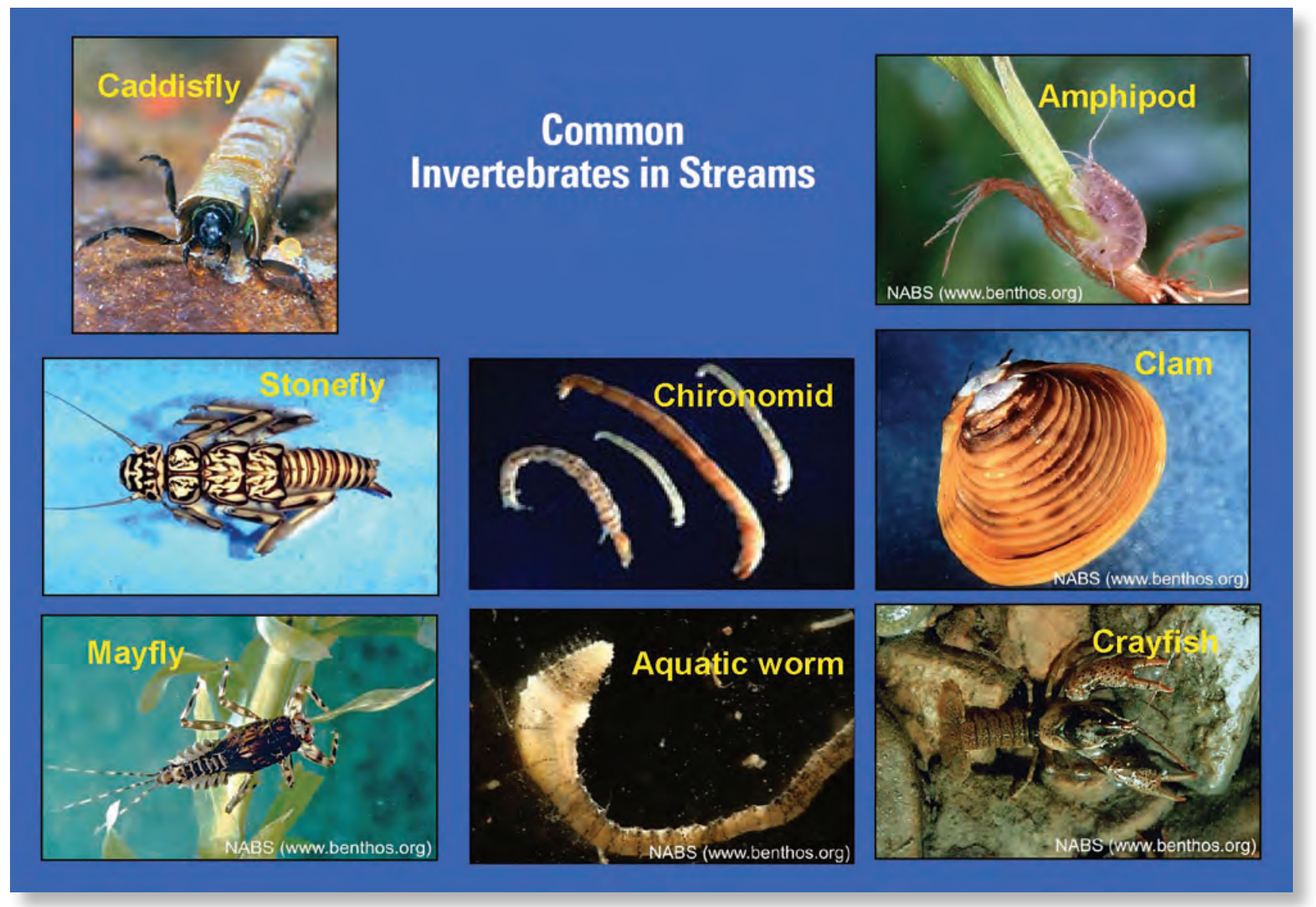

Aquatic invertebrates are an important part of stream ecosystems and are good indicators of stream health. The three photographs on the left are three insect Orders (Ephemeroptera=mayfly, Plecoptera=stonefly, and Trichoptera=caddisfly) that are sensitive to disturbance/contamination, and hence used as indicators of stream quality. Photographs from Society of Freshwater Science.

Invertebrates play a key role in stream ecosystems because they consume detritus (dead organic matter), aquatic vegetation, and animal material, and serve as an important food source for fish and wildlife. Invertebrates are animals without backbones and include worms (flatworms, nematodes, and annelids), mollusks (snails, clams, and mussels), crustaceans (amphipods and crayfish), and insects. Invertebrates are longer-lived than algae, having life spans ranging from months to years. Aquatic insects generally are the dominant invertebrate group in streams, consisting of numerous species, which vary in their role, from consuming bacteria and algae, to preying on other invertebrates. The dominant types of aquatic insects includes mayflies (Ephemeroptera), stoneflies (Plecoptera), caddisflies (Trichoptera), and "true" flies (Diptera); however, there are many other groups that are present to various degrees. Most aquatic insects spend most of the year in the stream and a relatively short period as terrestrial adults, such as caddisflies and mayflies. Although stream invertebrates are found in a wide variety of habitats, they are primarily associated with benthic (stream-bottom) substrates, such as rocks and woody debris. The types and numbers of invertebrates vary naturally in streams depending on a number of important factors, such as habitat, water temperature, and food resources. 


\section{The Role of Stream and Riparian Habitat}

The combination of physical factors that make up stream habitat provides the "home" that stream biota live on and in, and plays a key role in determining what species can reside in a particular stream system (fig. 2.6). Important stream features include bottom substrate (for example, rock and sand), water depth and velocity, water temperature, water clarity, and other features that add to the physical complexity of streams. Natural streams with complex instream habitat-including riffles, runs, and pools - support diverse aquatic communities. Alterations to streams, such as channelization or increased sedimentation, decrease the complexity of stream habitats, rendering the habitat unusable for some species.
Riparian habitat also is essential to the overall health of stream ecosystems. Riparian habitat is defined as the land buffer that runs along a stream and under normal conditions is dominated by natural vegetation. This vegetation can range from natural grasslands to forest to wetlands, all of which provide various types of protection to the stream. For example, forested riparian buffers provide food for the stream during leaf fall, shade the stream thereby maintaining cooler water temperature, and stabilize the streambank . Riparian buffers also provide important filtering mechanisms for reducing nutrients prior to their entering the stream.
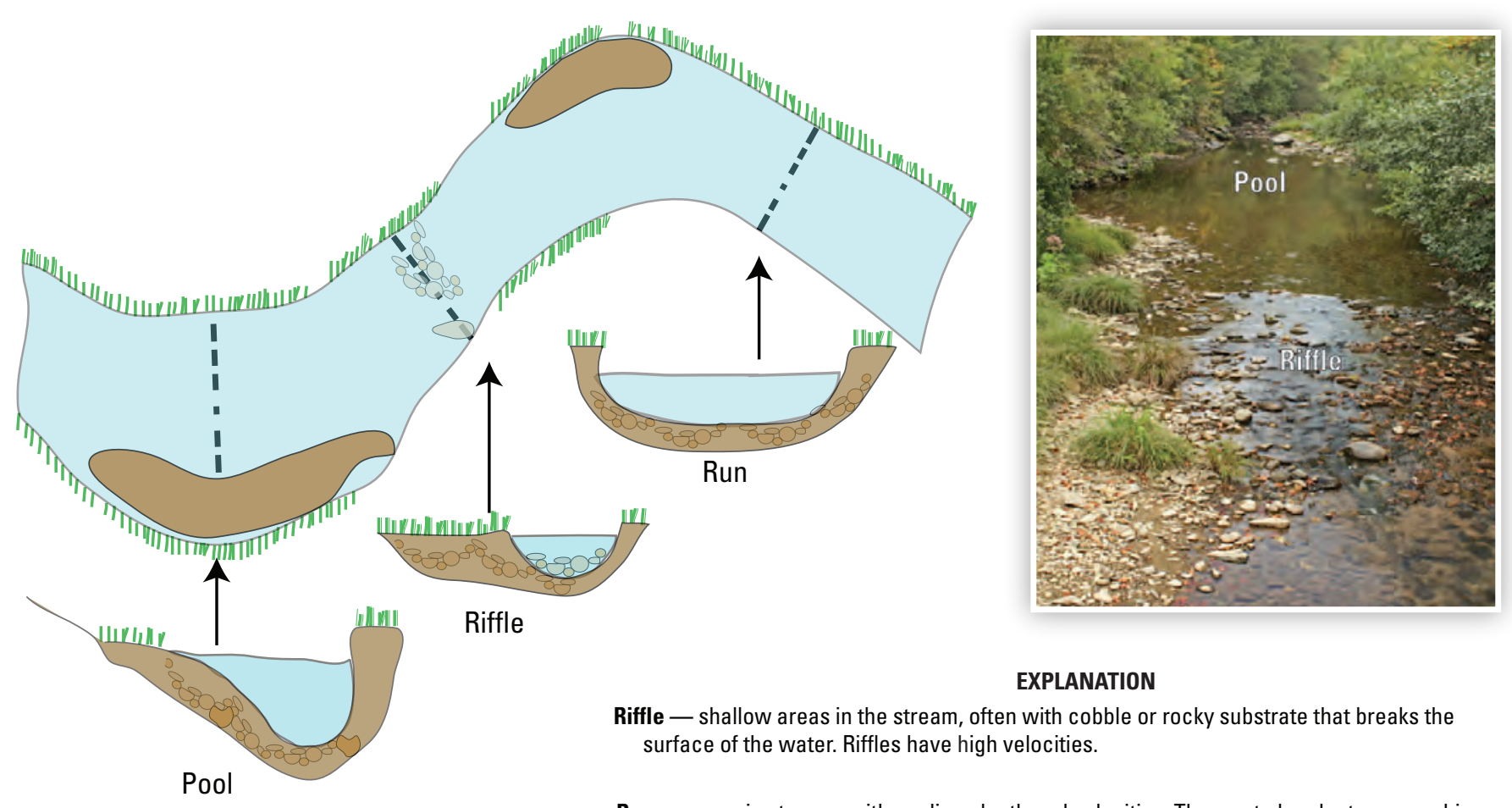

\section{EXPLANATION}

Riffle - shallow areas in the stream, often with cobble or rocky substrate that breaks the surface of the water. Riffles have high velocities.

Run — areas in streams with medium depth and velocities. The most abundant geomorphic unit in a stream.

Pool — areas in the stream that are deep with slow velocities. The deep water provides protection for fish and invertebrates.

Figure 2-6. Complex instream habitat (riffle-run-pool) supports diverse aquatic communities and often is the most important factor affecting which biological communities are found in a stream. Channelization of streams removes or reduces riffle and pool habitats along with the species that live there. 

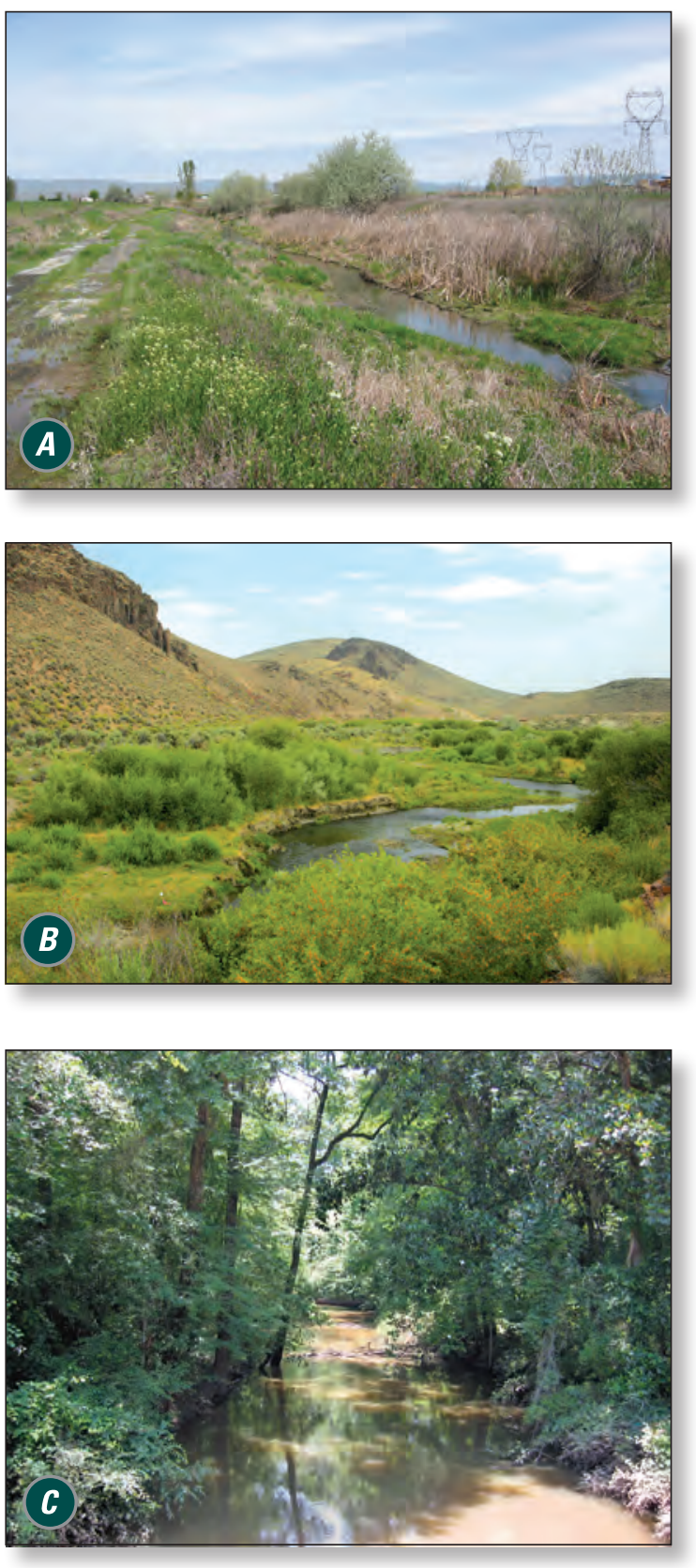

Photographs of three streams with contrasting riparian habitat. Photograph A, DR2, near Granger, Washington, is channelized and has an open canopy, taken by M.D. Munn, U.S. Geological Survey; $B$, Shoshone Creek, Nevada, has natural shrubland with moderate canopy cover, taken by M.D. Munn, U.S. Geological Survey; and $C$, an unknown stream in Georgia, has a natural riparian forested wetland with a closed canopy, taken by M.D. Munn, U.S. Geological Survey.

\section{How Excess Nutrients Alter Aquatic Ecosystems}

Although nitrogen and phosphorus are critical for sustaining stream ecosystems, excessive nutrients can cause various negative effects. A major problem associated with excessive nutrient concentrations in streams is eutrophication, which occurs when excessive nutrients stimulate the growth of aquatic vegetation. Excessive vegetation can result in the depletion in dissolved oxygen, which can have a detrimental influence on aquatic biota (Wong and Clark, 1979; Correll, 1998). This decrease in dissolved oxygen commonly occurs at night when oxygen production ceases but respiration continues, or during the autumn period when microbes consume dissolved oxygen while decomposing organic material (fig. 2-7). Low dissolved-oxygen concentrations resulting from nutrient over-enrichment are sometimes most evident in downstream lakes, bays, and estuaries. Notable examples include Lake Erie, the Chesapeake Bay, and the Gulf of Mexico. Although nutrient concentrations are rarely detected at levels toxic to biota (Rankin and others, 1999), low dissolved oxygen is sometimes associated with the release of toxic metals from sediments (Brink and Moore, 1996), and an increase in ammonia, which can be toxic at certain concentrations and temperatures. Excess nutrients also are associated with the occurrence of harmful algal blooms, which can produce toxins that affect fish and humans (Graham and others, 2010). Increased aquatic vegetation growth can slow water velocity leading to increased sediment deposition, reducing overall quantity and quality of habitat for invertebrates and fish (Wharton and others, 2006). Shifts in aquatic vegetation community composition can alter the overall food web due to changes in the quality of food available. All these factors cause a general loss in native biological diversity (Smith and others, 1999) and declines in economically important fish populations.

\section{Biological Indicators of Stream Quality}

Two general categories of biological indicators can be used to assess and monitor potential nutrient impacts to stream ecosystems. The first category includes the amount, or biomass, of aquatic vegetation. The most common method determines chlorophyll $a$, which is the dominant photosynthetic pigment used by both algae and aquatic plants, and therefore provides a simple estimate of relative biomass. For benthic algae, biomass is expressed as milligrams of chlorophyll $a$ per square meter (mg chlorophyll $\mathrm{a} / \mathrm{m}^{2}$ ). Assessing the biomass of larger aquatic vegetation, termed macrophytes, commonly requires harvesting large quantities of plant material within a specific area and determining either wet or dry weight. Alternatively, aquatic macrophytes are often assessed by their areal coverage (percentage of stream cover). A third approach is to monitor continuous 


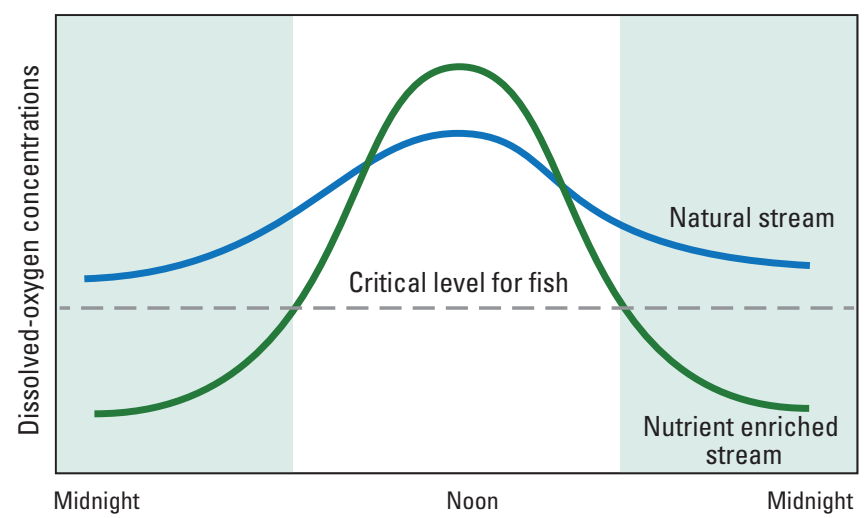

Figure 2-7. The daily concentration range of dissolved oxygen in natural streams with a low abundance of aquatic vegetation is much smaller than in nutrient enriched streams with extensive aquatic vegetation. When nutrient enriched streams contain large amounts of aquatic vegetation, dissolved-oxygen concentrations increase during the daytime due to photosynthesis and then decrease during the nighttime, sometimes below concentrations required to sustain fish.

dissolved-oxygen concentrations over time. The advantage of monitoring dissolved-oxygen concentrations is that the data are immediate and provide a direct measurement of aquatic vegetation production. Dissolved oxygen also is a strong monitoring tool because it is an important limiting factor for aquatic life.

The second category of biological indicator uses biological communities, often by quantifying the abundances and types of algae, invertebrates, and (or) fish. Many state and Federal agencies have incorporated biological community assessment into their water-quality programs. Although all three taxonomic groups provide useful information on the overall physical and chemical condition of streams, invertebrates and fish tend to reflect stream health, whereas changes in algal species better reflects nutrient conditions. Benthic algae and invertebrates are commonly used in the assessment of water quality and biological condition of streams because they (1) are ubiquitous, (2) are taxonomically well known, (3) include a large number of species that offers a wide range of responses to environmental stresses, (4) are somewhat sedentary and therefore indicative of local conditions, and (5) tend to integrate stressor effects (fig. 2-8).

Algae respond rapidly to short-term changes in nutrient concentrations and are highly effective indicators of nutrient enrichment. Algae have long been used as indicators of water-quality conditions and therefore the environmental requirements of many species have been well documented.
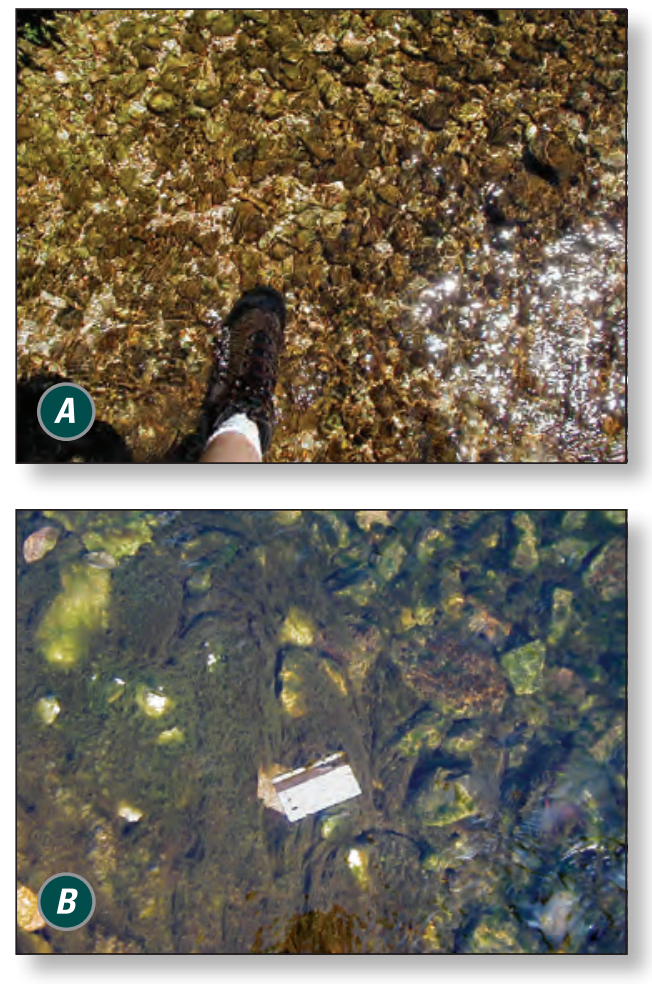

Reference site substrate with moderate biomass of algae, Beaty Creek, Arkansas $(A)$ and eutrophic site substrate with extensive algal biomass, Baron Fork, Arkansas $(B)$. Photographs taken by James Petersen, U.S. Geological Survey.

These requirements—-such as nutrient and habitat preferences, reproductive behavior, and lifespan —are all part of a species life history strategy. Because algal species have unique combinations of life history strategies and environmental preferences, their presence in a stream indicates a specificand sometimes narrow-range of environmental conditions. Species occurring in streams where water and habitat quality are degraded generally are limited to those organisms that are tolerant of existing physical and chemical properties of the stream environment. For example, the relative abundance of eutrophic diatoms in the algal community often increases as concentrations of nitrogen and phosphorus increase (Porter and others, 2008). Eutrophic diatoms, which are algal species that prefer streams with high nutrient concentrations, have a high relative abundance in areas of the country with intensive agriculture, such as the upper Midwest and in heavily urbanized areas. The relative abundance of various algal species may reflect other important environmental conditions, such as the concentration of dissolved oxygen or salinity (Porter and others, 2008). Algal metrics are increasingly being developed for assessment of stream impairment from nutrients by state and 
Federal agencies (Ponader and others, 2005; Belton and others, 2006). Several studies have found algae a more direct indicator of nutrient enrichment than invertebrate or fish communities (Stoddard and others, 2006; Justus and others, 2010).

Aquatic invertebrates respond to a broad range of stressors, with nutrients influencing invertebrates indirectly through changes in habitat, food quality and quantity, and decreased dissolved oxygen. The primary advantage of using benthic invertebrates includes relatively long life cycles (months to several years) that integrate stressor effects over longer time periods than algae. Although benthic invertebrates are good indicators of overall stream condition, they have limitations. For example, invertebrates respond to a number of human factors, which makes it difficult to isolate which stressor or combination of stressors causes a particular response.

\section{Unaltered biological communities}

\section{Altered biological communities}
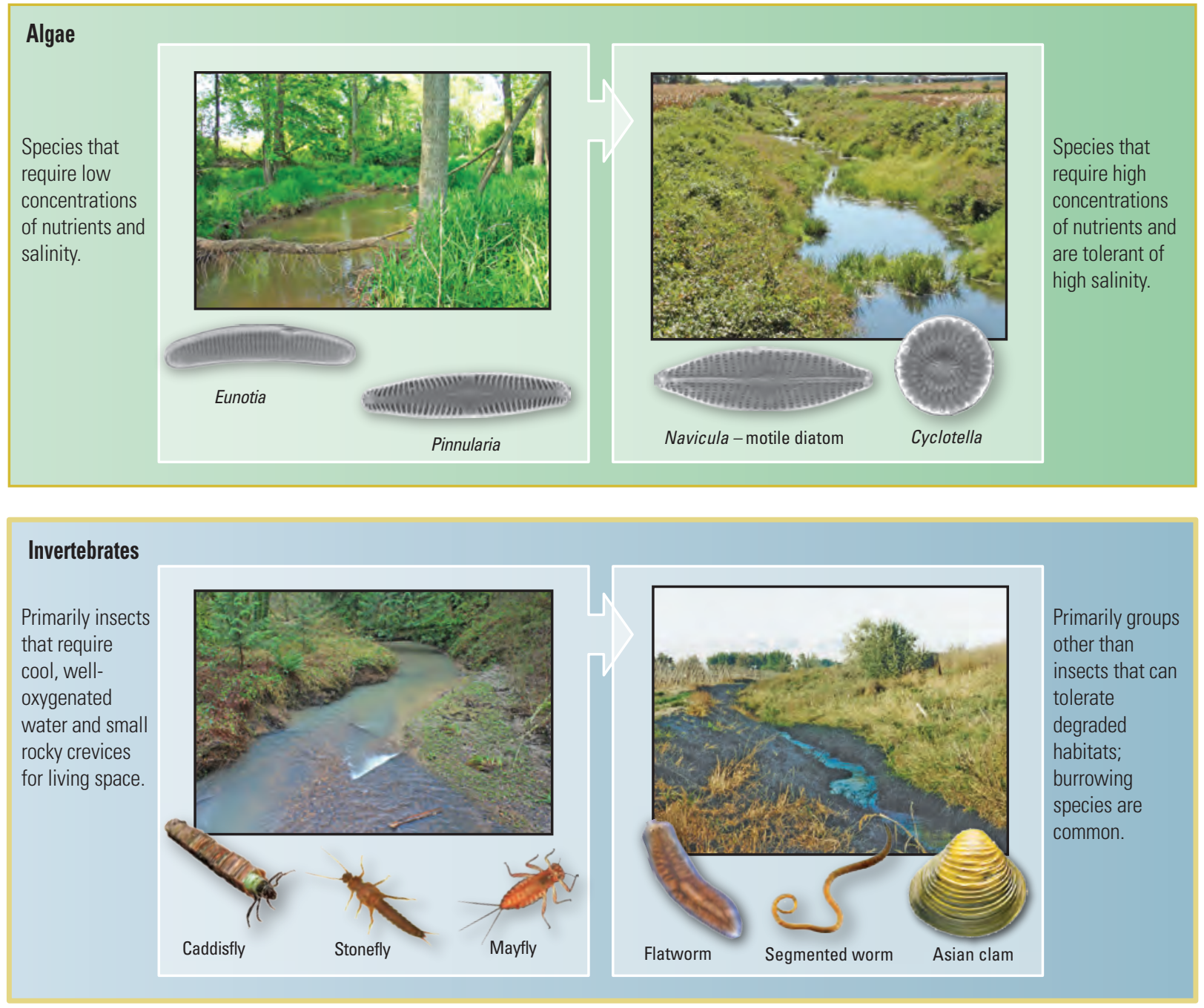

Figure 2-8. The traits of algal and invertebrate species typically found in unaltered biological communities differ from those in altered biological communities and are indicative of different physical and chemical changes to streams caused by human activities. Photographs show examples of unaltered and altered algal (Delmarva Peninsula, Maryland) and invertebrate (Yakima River, Washington) communities. 

percentage of agriculture and estimated nutrient input. The percentage of agricultural land use in watersheds in these eight areas spans the range of agricultural land use in the United States (fig. 3-2), which has a median of 10 percent agriculture.

\section{Regional Differences}

The eight areas were grouped into three regional categories (fig. 3-1) based on two primary factors. First, the region boundaries follow the established physiographic subdivision of the conterminous United States - the intermontane plateaus division, the interior (interior plains and interior highlands divisions), and the Atlantic plain division (Fenneman and Johnson, 1946). These broad divisions are separated, for the most part, by mountainous regions that contain only a small percentage of the Nation's farm land (National Agricultural Statistics Service, 2008). Second, the three regions are distinct in terms of their elevation, mean annual air temperature, and mean annual precipitation (fig. 3-3).

Western Region.- The two arid Western Region areas are at higher elevation and have steeper basin slopes than the other study areas; the combination of low precipitation and little surface runoff resulted in streamflows heavily dominated by base flow (that is, groundwater discharged to the stream). The agricultural settings in these areas are dominated by a combination of dryland and irrigated agriculture, and cattle production. The Central Columbia-Yakima River in eastern Washington (henceforth Columbia Plateau) and Upper Snake
River Basin (henceforth Snake River) of southeastern Idaho and northeastern Nevada (fig. 3-1) are naturally covered by sagebrush and grassland, and underlain by thick deposits of basalt (fine-grained volcanic rock). Where the basalt is mantled by deposits of loess or alluvium, it may support productive cropland or orchards when irrigated, although dryland farming does occur in the eastern part of the Columbia Plateau. The Columbia Plateau also features grazing and

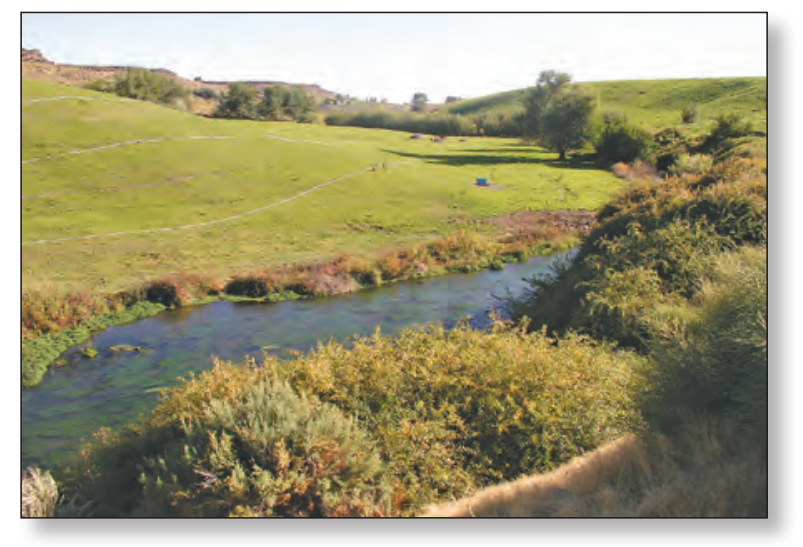

Many agricultural streams in the Western United States are in arid lands with narrow riparian zones. Billingsley Creek, Idaho, Christopher Mebane, U.S. Geological Survey, September 25, 2006.

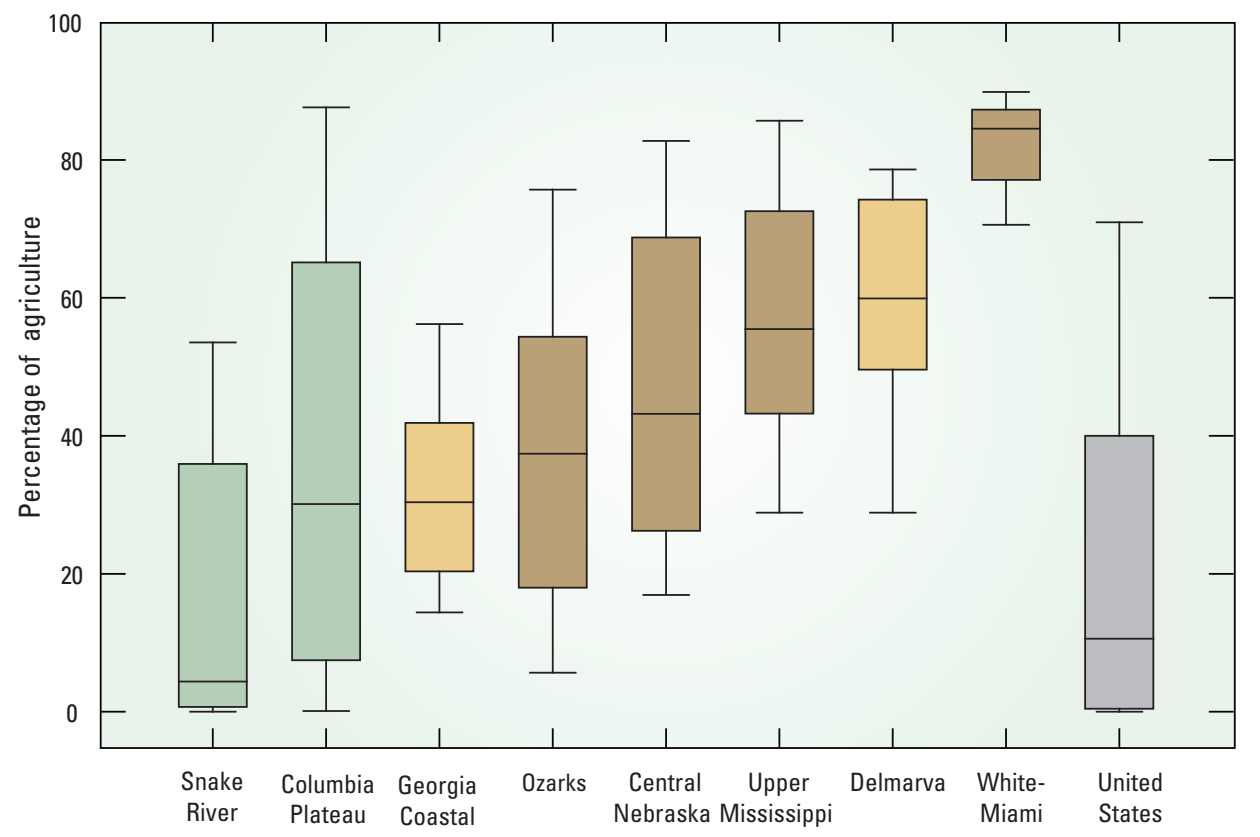

Figure 3-2. Percentage of agricultural land use in watersheds in the eight study areas spans the range of agricultural land use in watersheds in the United States.

\section{EXPLANATION}

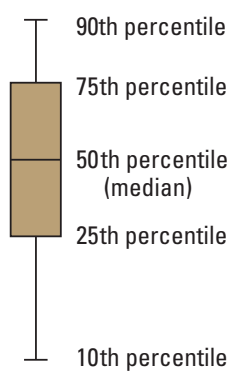

Study areas

Western Region

Central Region

Eastern Region 
Study areas grouped by physiographic divisions of the conterminous United States

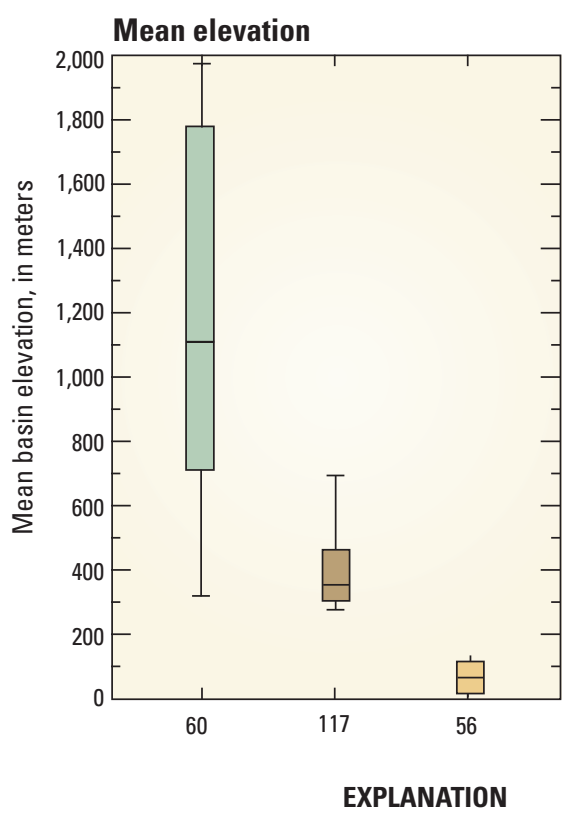

\begin{tabular}{ll} 
90th percentile & \multicolumn{1}{c}{ Study areas } \\
75th percentile & $\square$ Western Region \\
50th percentile & $\square$ Central Region \\
(median) & \\
25th percentile & \\
10th percentile &
\end{tabular}

60 Number of sampling sites
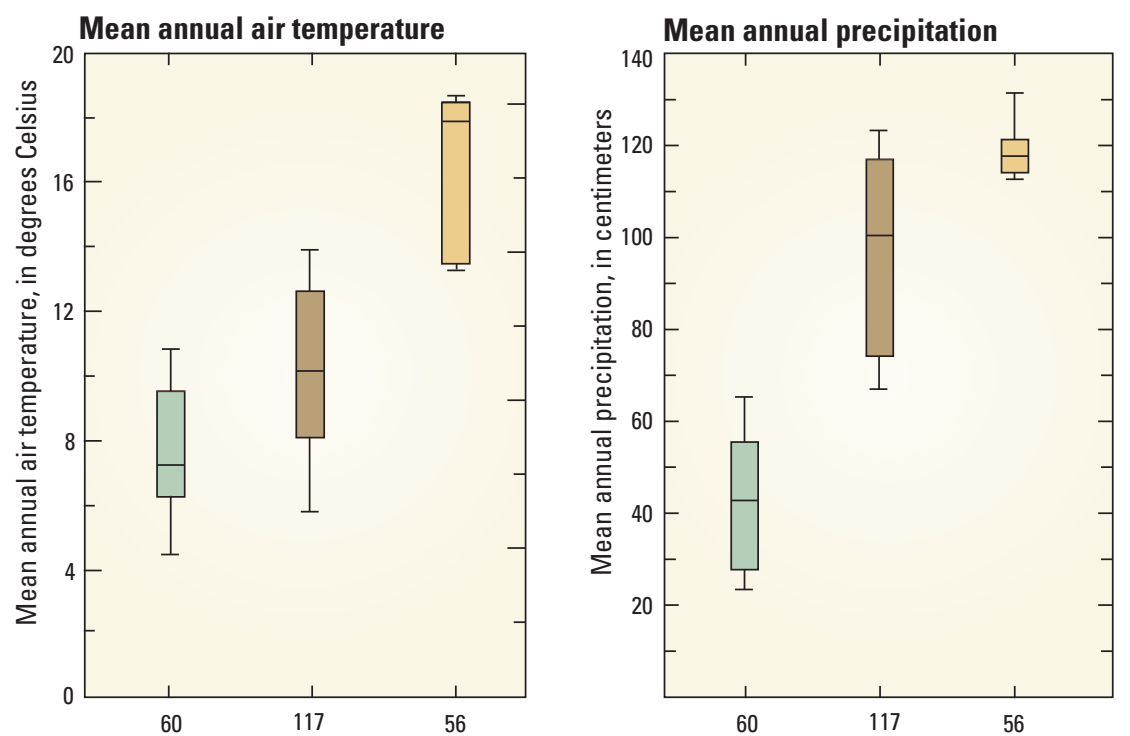

Figure 3-3. The eight areas fall into three naturally distinct environmental settings: Western Region study areas, characterized as having high elevation, cool temperatures, and low precipitation; Central Region study areas, characterized as topographic and climatic intermediates; and Eastern Region study areas, characterized as having low elevation, warm temperatures, and high precipitation. dairy cattle. Nationally important agricultural commodities produced in the Snake River include potatoes, sugar beets, alfalfa, dairy, and beef cattle. Except for the irrigated cropland in the alluvial valleys bordering the Snake River, most of the remainder of the Snake River features a sagebrush steppe used primarily for grazing.

Central Region.-As the largest region, the Central Region has the greatest diversity of environmental settings. The four Central Region areas encompass a broad range of climate, water management (irrigation dependency and subsurface drainage), hydrogeology (stream-aquifer interaction, depth to groundwater, streamflow variability, and base-flow dominance), and surficial deposits. The Central Nebraska study area lies within the central Great Plains, a subhumid to semiarid region of native grasslands largely converted to cropland (mostly corn) (fig. 3-1). The Ozark Highlands in Arkansas, Missouri, and Oklahoma (henceforth Ozarks) comprise largely forested, dissected limestone plateaus with karst features including springs and spring-fed streams throughout much of the region. The Upper Mississippi River Basin in Minnesota and Wisconsin (henceforth Upper Mississippi) lies in a transition zone between forests to the northeast and agricultural activities to the southwest. The Upper Mississippi landscape is a mosaic of cropland, pasture, native hardwood forest, wetlands, and lakes, reflecting the varied surficial geologic materials deposited by ice or sorted

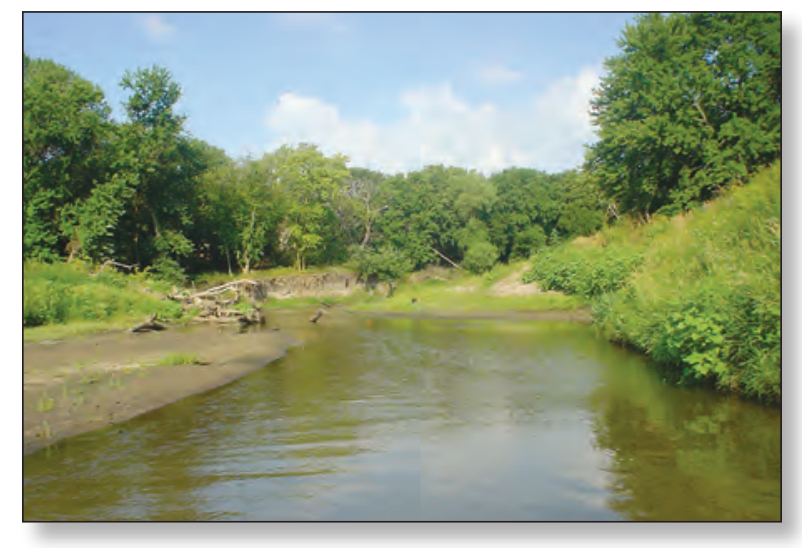

Many streams in the Central Region, like Maple Creek in Nebraska, have intact riparian buffers. Photograph taken by M.D. Munn, U.S. Geological Survey, August 5, 2003. 
by glacial meltwater. The White, Great Miami, and Little Miami River Basins of Indiana and Ohio (henceforth, WhiteMiami) encompass a rolling plain of rich, glacial till-derived soils, where row crops have largely displaced the native hardwood forests, except along riparian corridors.

Both the Ozarks and White-Miami areas generally have clay-dominated soils, yet their differing land-use patterns reflect contrasting topography. The extensive, artificial subsurface-drainage systems beneath the low-relief topography
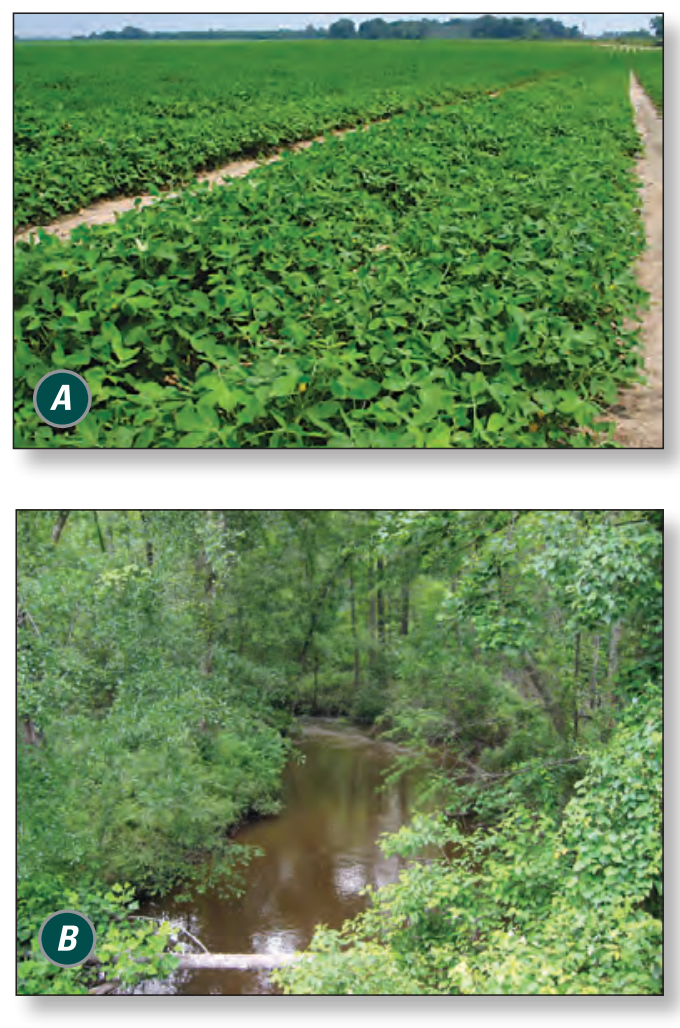

In the Eastern Region, cropland can be confined to uplands due to substantial forested riparian wetlands. (A) Peanut crop, Georgia; photograph taken by Daniel Calhoun, U.S. Geological Survey; $(B)$ unknown forested riparian stream, Georgia; photograph taken by M.D. Munn, U.S. Geological Survey, June 2, 2003. in the White-Miami area enable its prolific production of corn and soybeans. In the steep, high-relief topography of the Ozarks, slopes are unsuitable for cultivation-only one study site drained more than 2 percent cultivated cropland. As a result, agricultural activity in the Ozarks mostly involves poultry production and cattle-grazed pastures.

Eastern Region.-The two Eastern Region areas lie on unconsolidated coastal sediments. The drainage basins of these two areas are relatively flat with warm humid climates and abundant precipitation (fig. 3-3). The Delmarva Peninsula (henceforth, Delmarva) (fig. 3-1) is on the Northern Atlantic Coastal Plain, a flat plain underlain in most areas by permeable sediment (Denver and others, 2010) where native hardwood forest and wetlands have largely been converted to cropland, except in riparian areas. The Delmarva also contains one of the Nation's greatest density of chicken production (National Agricultural Statistics Service, 2010). The Georgia Coastal Plain study area (henceforth, Georgia Coastal) contains cropland and nut orchards that have displaced much of the native forests, predominantly longleaf pine, except in alluvial bottom lands where woody wetlands remain dominant. Much of this area has sandy, permeable soils that readily transmit water and dissolved nutrients such as nitrate to the shallow water table.

\section{Nutrient Sources}

Nutrient inputs varied within and among regions and study areas. The largest sources of nutrients in agricultural areas are nonpoint sources, such as livestock manure and fertilizer applications. Commercial fertilizer was the predominant source of nitrogen in six of the areas, with the largest application in the Central Nebraska, White-Miami, and Delmarva (fig. 3-4A). Animal manure was the dominant source of nitrogen in the Snake River and Ozarks.

Animal manure contributed a larger proportion of the phosphorus nonpoint sources than of the nitrogen sources (fig. 3-4B). Commercial fertilizer and manure contributed similar amounts of phosphorus in the Columbia Plateau, Snake River, Central Nebraska, and Upper Mississippi. The phosphorus inputs were predominantly from manure in the two areas where poultry numbers are greatest - the Ozarks and Delmarva. Although geologic sources of phosphorus can be substantial—especially in the rangelands of the Western United States (Dubrovsky and others, 2010)—-they were not quantified for this study. 

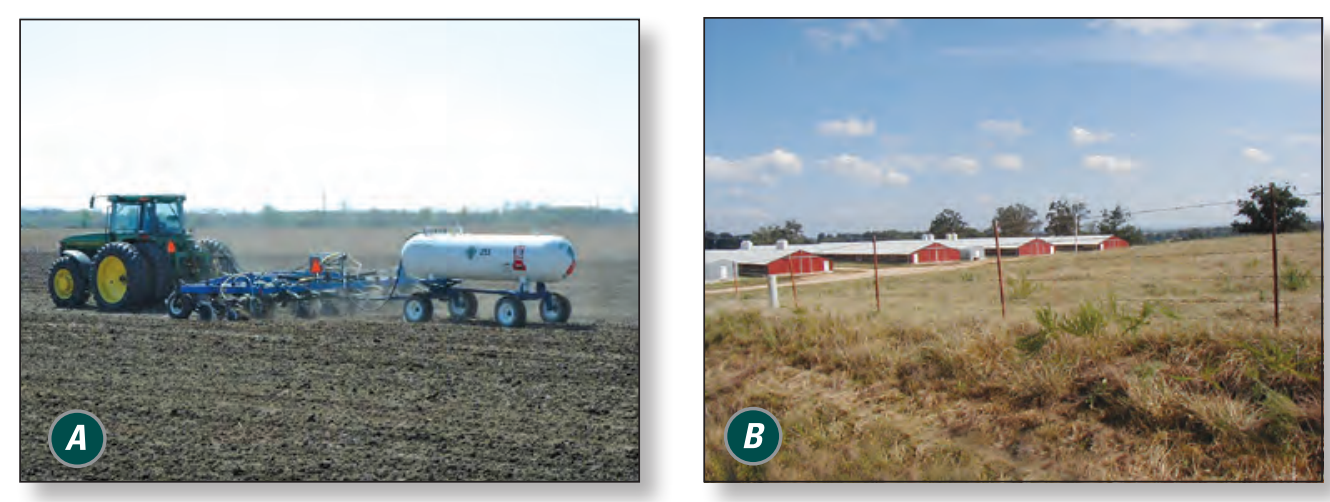

(A) Fertilizer application;

photograph taken by Tim McCabe,

U.S. Department of Agriculture, and

$(B)$ chicken houses in Arkansas;

photograph taken by James

Petersen, U.S. Geological Survey,

September 15, 2004.

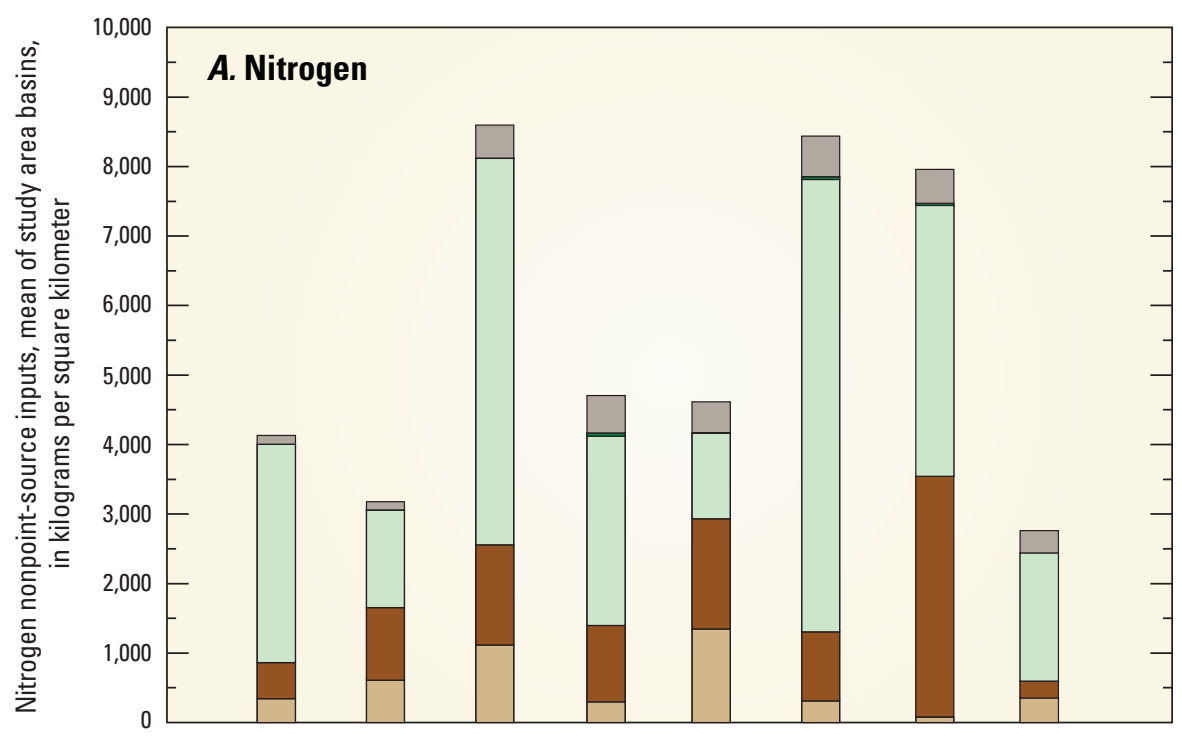

\section{EXPLANATION}

Nutrient-source categories

Atmospheric deposition, 2001-04 mean

Fertilizer, nonfarm use, 2001-04 mean

Fertilizer, farm use, 2001-04 mean

Manure, confined livestock, 2002

Manure, unconfined livestock, 2002

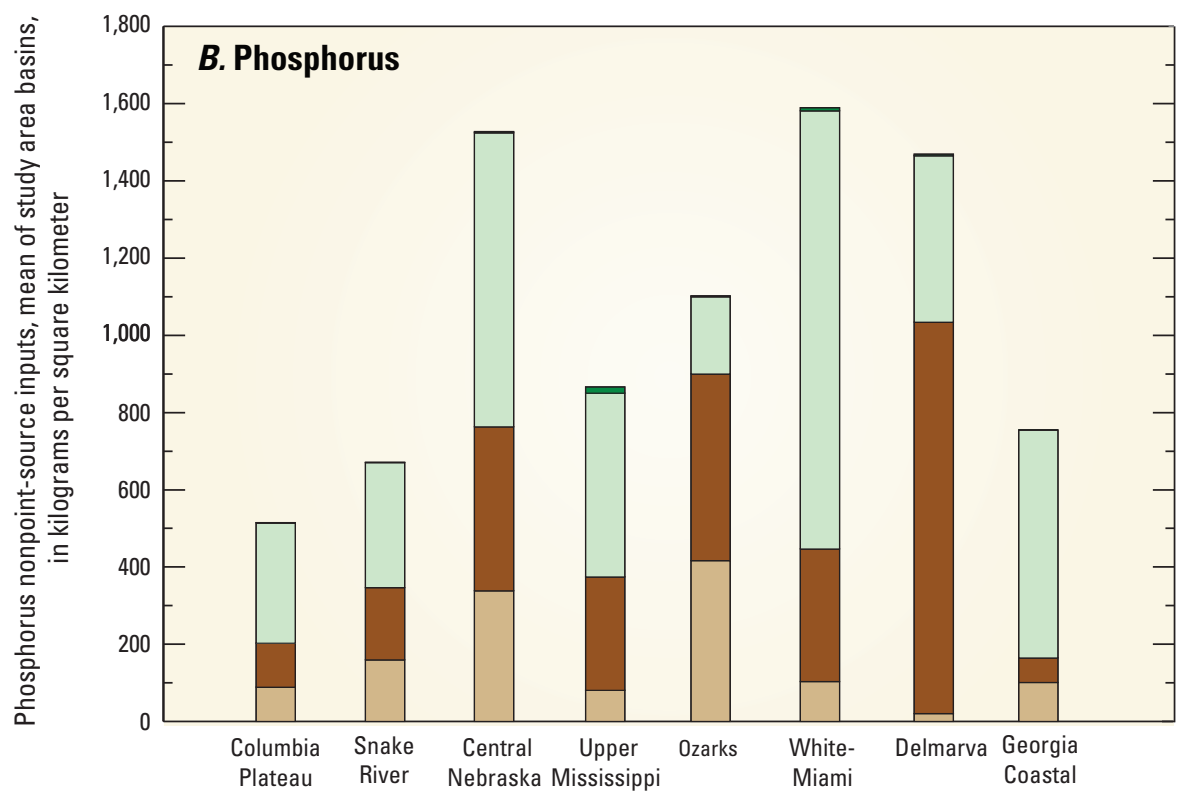

Figure 3-4. For most areas, nonpoint sources of nitrogen $(A)$ are dominated by agricultural use of commercial fertilizers, whereas fertilizer and manure are equally important nonpoint sources of phosphorus $(B)$. 


\section{Riparian Buffers}

Riparian buffers are important in agricultural systems because of their ability to reduce nutrient transport to streams. However, when riparian areas are reduced or excess nutrients are predominantly transported by tile drainage or deeper groundwater flow paths, riparian vegetation offers little protection from nutrient inflows to streams. Agricultural streams in this study had a wide variety of riparian conditions ranging from natural intact woodlands and wetlands to riparian buffers replaced by cropland. The percentage of woodlands and wetlands in the 100-m riparian buffer was generally lowest in the western study areas and highest in the eastern study areas, whereas the percentage of cropland did not show a distinct pattern (fig. 3-5). The natural condition of the riparian areas in the Eastern Region areas reflects the dominance of wetland systems that border many of the agricultural streams.
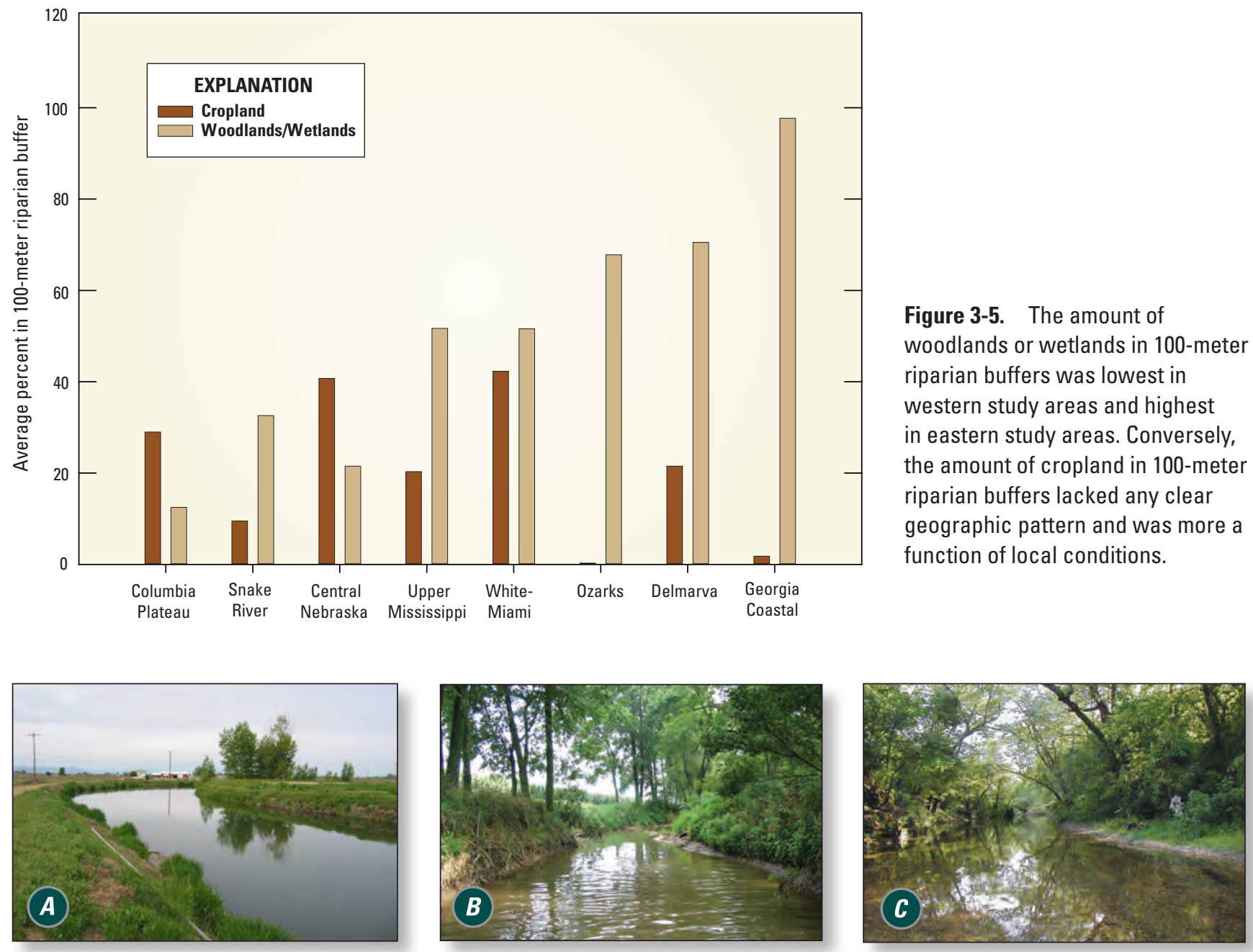

Examples of three types of riparian areas in this study: $(A)$ clearing and cultivation of riparian woodland or overgrazing by livestock has resulted in reduced natural vegetation along some Central Nebraska streams (Turkey Creek near Elm Creek, Nebraska [photograph taken by M.D. Munn, U.S. Geological Survey]); $(B)$ a typical White-Miami stream with a thin riparian area and with crops planted adjacent to the riparian buffer (Mud Creek, Indiana [photograph taken by M.D. Munn, U.S. Geological Survey, August 18, 2004]); (C) extensive riparian areas with woodland canopy is common in the Ozarks (Dry Fork, Arkansas [photograph taken by James Petersen, U.S. Geological Survey, August 17, 2005]).
Figure 3-5. The amount of woodlands or wetlands in 100-meter riparian buffers was lowest in western study areas and highest in eastern study areas. Conversely, the amount of cropland in 100-meter riparian buffers lacked any clear geographic pattern and was more a function of local conditions. 


\section{How Sites Were Selected}

Sites within a study area were selected to minimize natural variability and maximize the range in nutrient concentrations. In order to reduce natural regional variability from soils, climate, hydrology, and natural vegetation, all sites in a study area were limited to an EPA Level 3 Ecoregion (Omernik, 1987; U.S. Environmental Protection Agency, 2007). Estimates of total nitrogen and total phosphorus inputs to watersheds in a study area were used to assess potential nutrient conditions at candidate sites (Ruddy and others, 2006). This approach resulted in 28-30 stream sites in each of the eight study areas. Estimated nutrient input to basins in five of the study areas is similar to that of similarly sized basins in the United States ( $\mathrm{n}=19,000$ basins with hydrologic unit code 10), but was higher for basins in the Central Nebraska, White Miami, and Delmarva than for the United States (fig. 3-6).
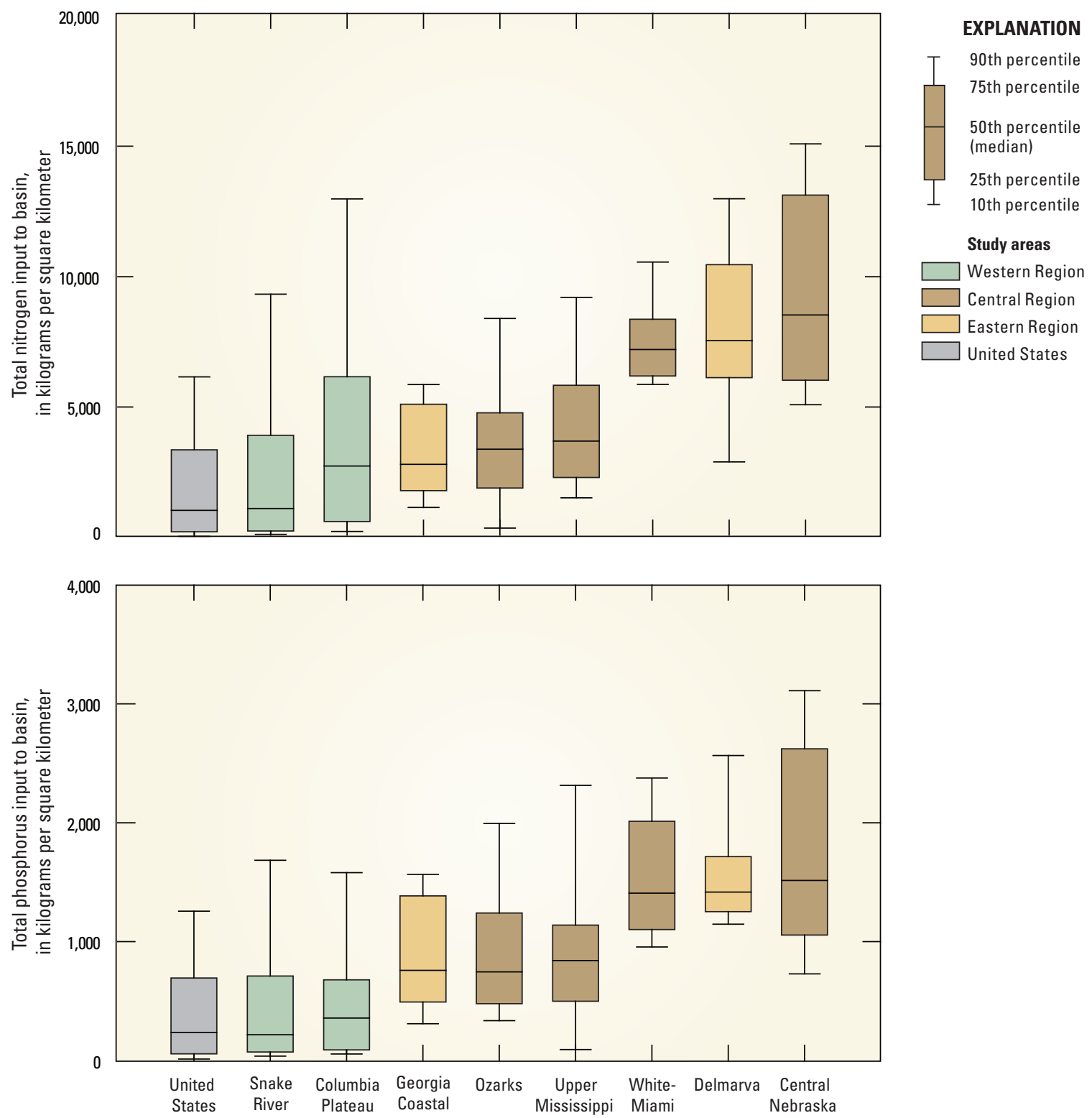

Figure 3-6. Estimated nutrient input to basins in five of the study areas is similar to that of similarly sized basins in the United States ( $n=19,000$ basins with hydrologic unit code 10), but was higher in three of the areas. 


\section{Methods and Data Collection}

This study consisted of 232 sites distributed among eight areas. All 232 sites were used to assess the aquatic vegetation and biological community objectives; whereas, a subset of the sites was used to address primary production (46 sites) and nitrogen processing (7 sites). The study was conducted from 2003 to 2009, with sampling during stable streamflow conditions to minimize streamflow-driven nutrient variability, and avoid underestimating algal biomass or community composition due to scouring high streamflows. Details on the sampling design, collection methods, and data used in this report are provided by Brightbill and Munn (2008), Brightbill and Frankforter (2010), and Munn (2018).

Watershed-scale and riparian characteristics were obtained using available data sources that were consistent and comparable among all areas and analyzed with geographic information analysis techniques (Johnson and Zelt, 2005). Nutrient concentrations in water (ammonia, nitrite, nitrate, organic nitrogen, total nitrogen, orthophosphate, and total phosphorus) were measured twice-30 days prior to and during biological sampling. Except where indicated otherwise, nutrient concentrations presented in this report represent the average for the two samples. Stream habitat data were collected along 100-150 m stream reaches using methods outlined in Fitzpatrick and others (1998). Additional information on methods and data collected is presented in Brightbill and Munn (2008) and Brightbill and Frankforter (2010).

The amount of aquatic vegetation was assessed at 232 sites by determining benthic algal biomass and macrophyte cover. Benthic algal biomass (mg chlorophyll a/ $\mathrm{m}^{2}$ ) was measured on rock or wood substrate using methods outlined in Moulton and others (2002). When sites were dominated by fine-grained sediment, a modified method was used (Munn and others, 2002). Percent cover of macrophytes was assessed along the habitat transects using methods adopted from Biggs and Kilroy (2000).

Primary production was determined at 46 of the 232 sites using the upstream-downstream oxygen budget method over a 48-hour period (Bales and Nardi, 2007; Frankforter and others, 2009). Meters that continuously measure dissolved-oxygen concentration were placed at the upstream and downstream boundaries of 100-150 m long reaches. Other continuous measurements included photosynthetically active radiation and water temperature.

Biological communities were assessed at the 232 sites using methods outlined in Moulton and others (2002). Communities assessed included benthic algae and invertebrates; fish were assessed only in the White Miami (Caskey and Frey, 2009) and the Ozarks (Justus and others, 2010) but results are not presented in this report. Algal and invertebrate communities were assessed using a combination of community composition and indicator taxa to reflect biological condition. One effective measure of biological condition compares the observed number of taxa at a sampling site to the number of taxa expected based on a set of regional reference sites, commonly referred to as the $\mathrm{O} / \mathrm{E}$ score. The biological condition metric is a percentage value based on the number of taxa observed $(\mathrm{O})$ at a given site divided by the expected (E) number of taxa at that site given no disturbance (Van Sickle and others, 2005; Carlisle and Meador, 2007). It is important that reference sites appropriate for different regions be selected because the quality of reference sites available in a region is the basis for determining biological condition. In this report, expected biological condition was estimated within each of the three regions from minimally disturbed reference streams with low Agricultural Intensity Index scores (see section, “Agricultural Intensity Index”). Streams with O/E scores greater than 80 percent represent unaltered biological conditions, whereas streams with scores less than 80 percent are considered to have an altered biological condition (Carlisle and Meador, 2007). This percentage represents a 20 percent loss of expected taxa for a region and may reflect the elimination of important components of the food web resulting in diminished stream ecosystem conditions.

Biological condition also is assessed using the occurrence or relative abundance of particular benthic algae and invertebrate taxa. One of the most commonly used invertebrate metrics in biomonitoring programs is EPT richness, which is the sum of aquatic insect taxa in the orders Ephemeroptera (E; mayflies), Plecoptera (P; stoneflies), and Trichoptera (T; caddisflies) that are intolerant to environmental alterations. The loss of EPT taxa often is associated with a shift in community composition to
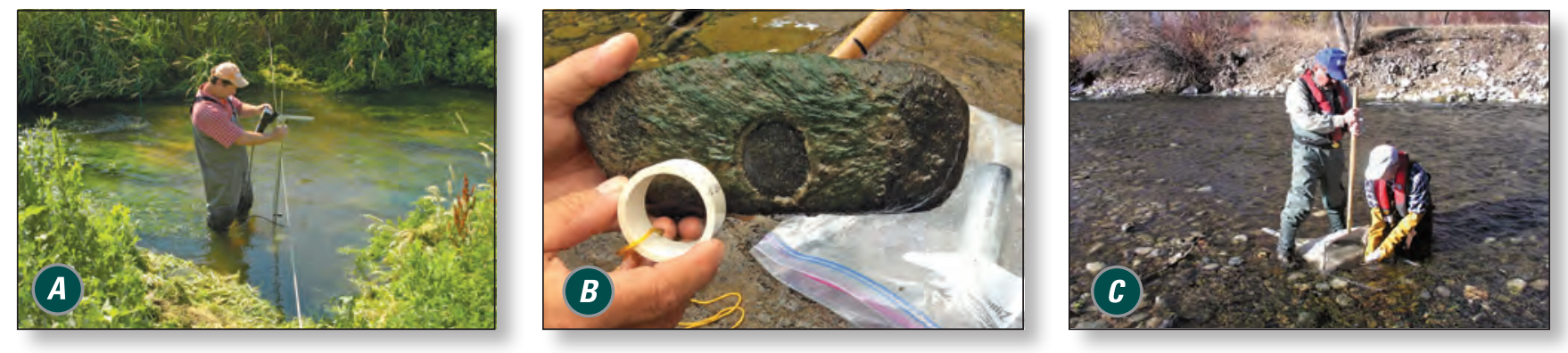

Sampling habitat $(A)$, benthic algae $(B)$ and invertebrates $(C)$. Photograph $A$ taken by D.A. Wentz, U.S. Geological Survey, July 13,2007 . Photographs $B$ and $C$ taken by Christopher Mebane, U.S. Geological Survey. 


\section{Agricultural Intensity Index}

An Agricultural Intensity Index (AII) was developed that incorporated important landscape properties to measure the combined influence of estimated nutrient inputs and transport pathways within the watershed. Agricultural practices vary widely, often resulting in differences in the effects of these practices on water quality and physical habitat. The AII permits the ranking of watersheds based on potential nutrient effects, correlates better with biological condition than nutrient concentrations or nutrient inputs, and allows comparison of watersheds of varying size (Waite, 2013). The AII combines four landscape-based attributes (Waite, 2013): (1) percentage of agricultural land use in the watershed, (2) percentage of agricultural land use in the riparian buffer, (3) estimated nitrogen inputs, and (4) estimated phosphorus inputs. Each variable had equal weight, and the total scores were rescaled to a percentage ranging from 0 (low) to 100 (high) agricultural intensity (fig. 3-7).
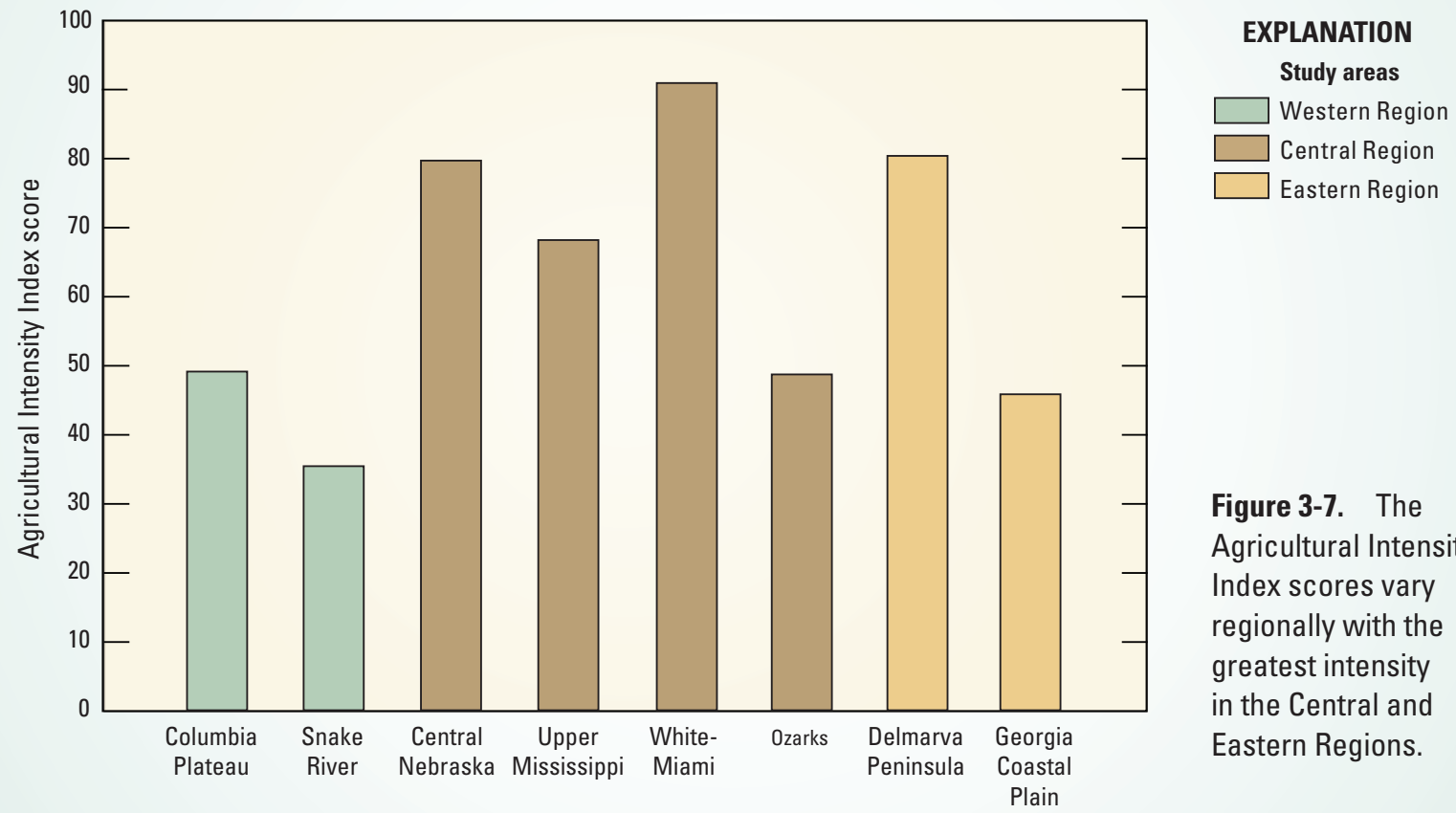

Figure 3-7. The Agricultural Intensity Index scores vary regionally with the greatest intensity in the Central and Eastern Regions.

more tolerant organisms, many of which typically are non-insect invertebrates (Lenat, 1988). This metric is particularly effective in evaluating nutrient concentrations in wadable streams (Miltner and Rankin, 1998). Similarly, the relative abundance of eutrophic algal taxa (species that prefer elevated nutrients) is a stressor-specific algal metric commonly used to evaluate nutrient concentrations in streams (Van Dam and others, 1994; Porter and others, 2008). The presence of eutrophic algae increases incrementally with increasing agricultural land cover in the watershed (Porter and others, 2008).

A nitrogen transport and transformation study was done at seven sites distributed across various agricultural areas. In this study, stream discharge and nutrient chemistry data from various environmental compartments were used to develop conceptual and computational models of the proportion of stream nutrients derived from various pathways. These studies were conducted at sites spanning a range of lowgradient agricultural environments, crop types, and stream configurations. Each study was conducted during low flow when biological processes were most likely to influence nitrogen transformations. At each of the seven study reaches, surface-water and groundwater inflows were measured by adding a bromide tracer to the stream for 72 hours (Duff and others, 2008). Additional hydrologic stream properties were described by fitting the bromide tracer data using a model with inflow and storage (Sheibley and others, 2014). A reach-scale nitrate mass balance-which compares the nitrate inputs and outputs - was then calculated to determine whether each stream reach was gaining or losing nitrate (see Chapter 4, fig. 4-4, for more details). 

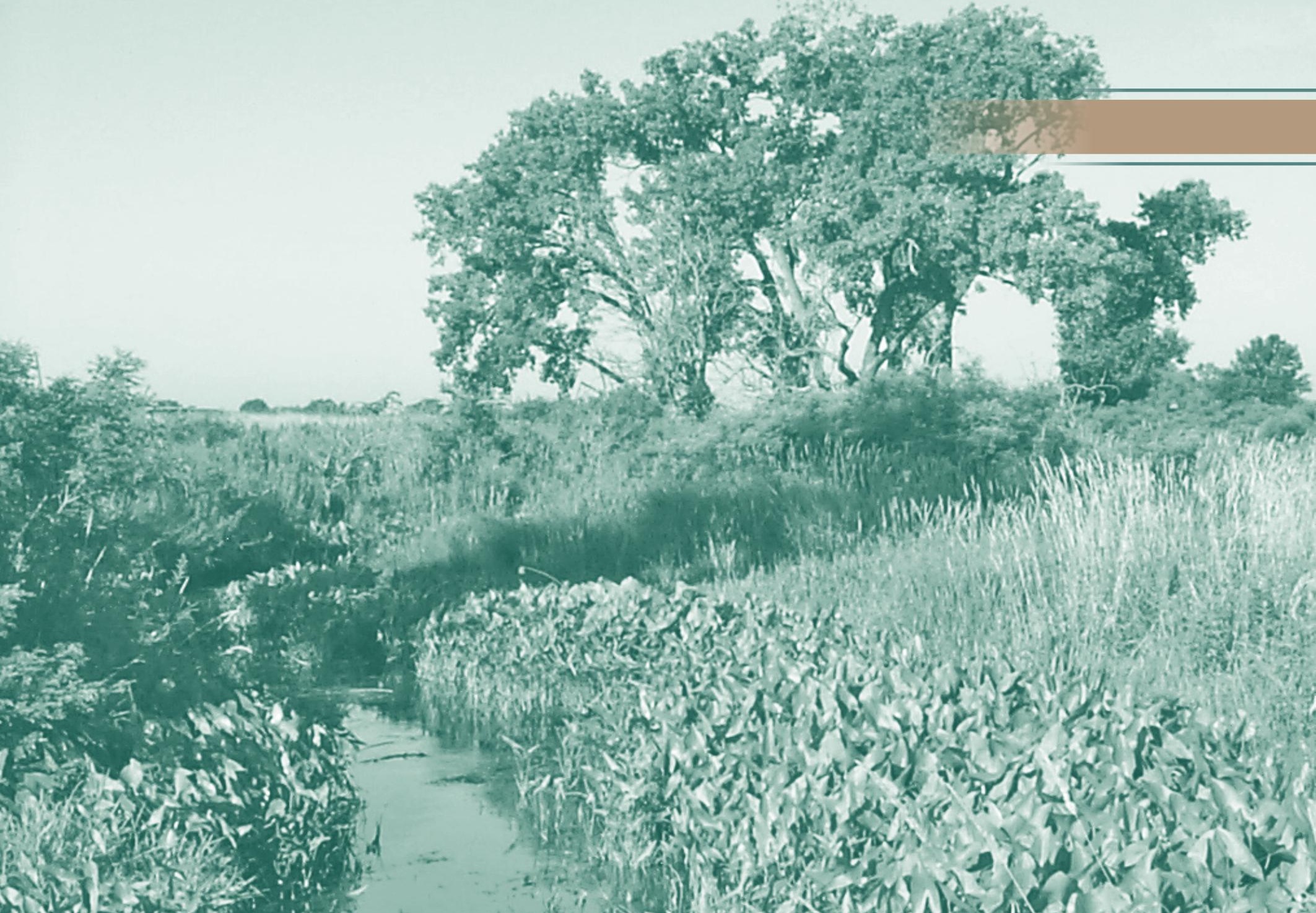

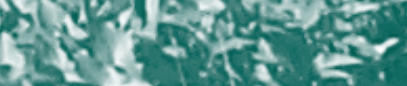
atesir X. is.

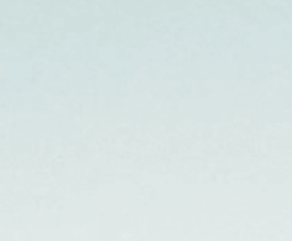
H.

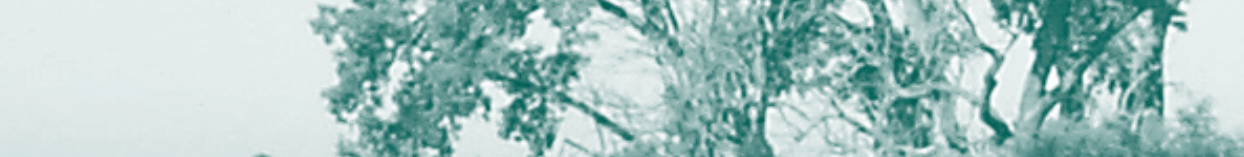

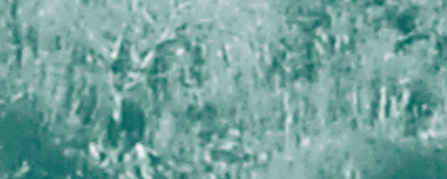

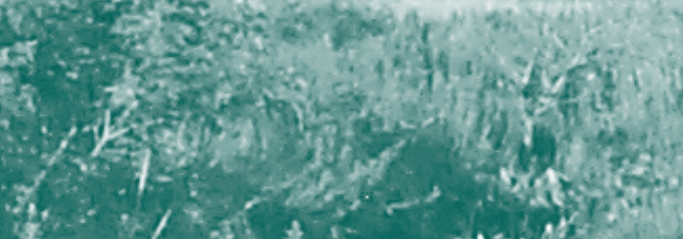

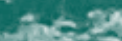

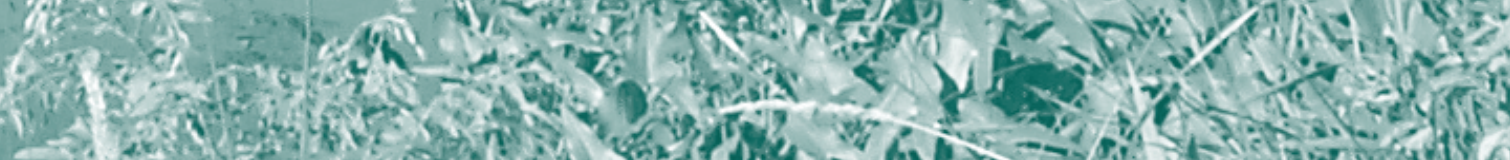

1. Non

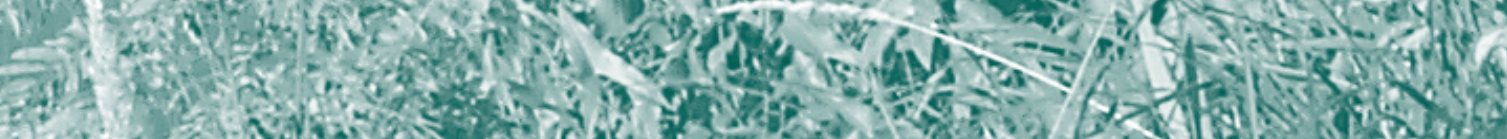

( W

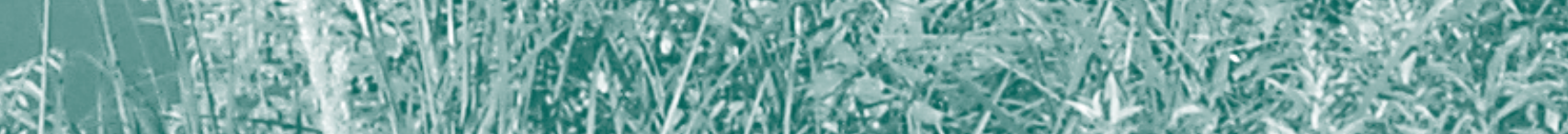

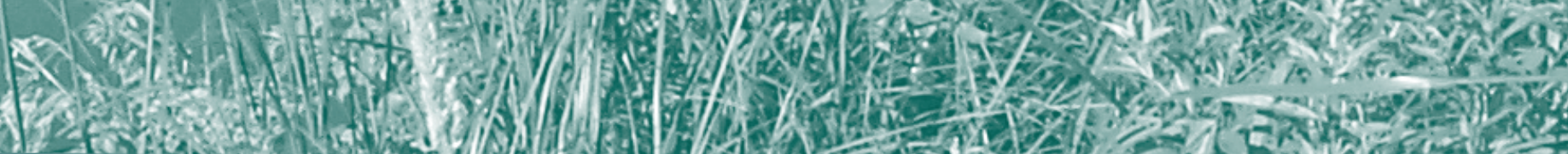

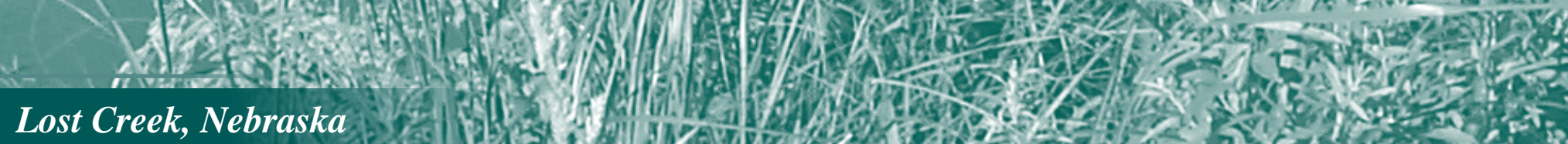

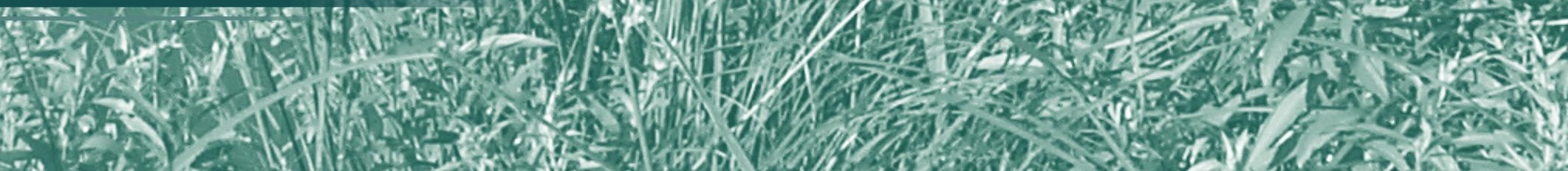




\section{Chapter 4. Nutrients in Surface Waters-Pathways and Processes}

\section{Introduction}

Stream nutrient concentrations are determined by inputs of nutrients to the watershed, hydrologic pathways that transport nutrients to streams, and biological processes. Understanding these factors and processes helps scientists and resource managers identify best management strategies for improving stream health. This chapter addresses nutrient concentrations in streams, and how these concentrations are influenced by inputs, pathways, and biological processes.

\section{Nutrient Concentrations in Agricultural Streams}

Concentrations of total nitrogen and total phosphorus typically were higher than modeled background concentrations and proposed EPA regional nutrient criteria.

Total nitrogen and total phosphorus concentrations in streams were highest in areas with large amounts of row-crop agriculture - the Central Nebraska, White-Miami, and Delmarva (fig. 4.1); row crop agriculture requires the highest application of nitrogen relative to other land use practices. Stream concentrations of total nitrogen were relatively low in the Ozarks area where land use is dominated by pasture and forested lands. High concentrations of total phosphorus in the

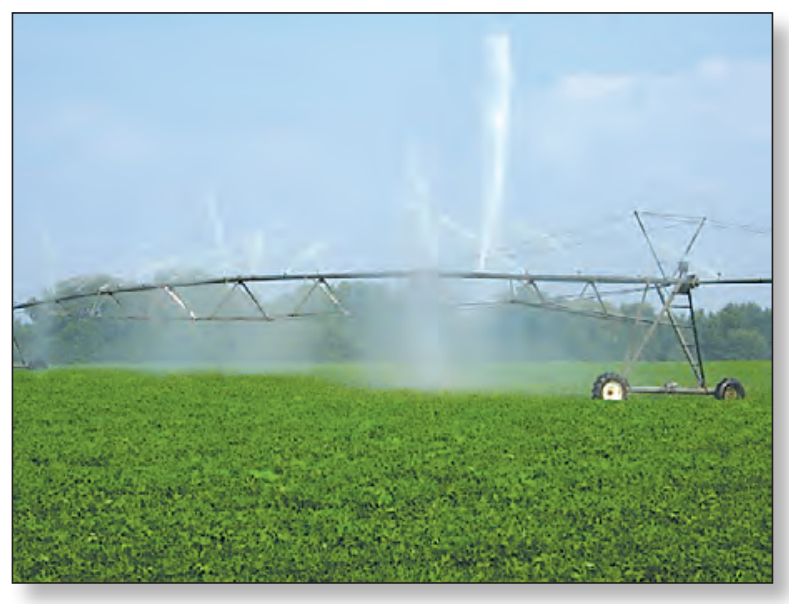

\section{Agricultural inputs and practices have a great effect on stream nutrient concentrations. Photograph taken by Daniel Calhoun, U.S. Geological Survey.}

Central Nebraska study area are likely due, in part, to high concentrations of orthophosphate in groundwater discharging to streams (Tesoriero and others, 2009; Domagalski and Johnson, 2011).
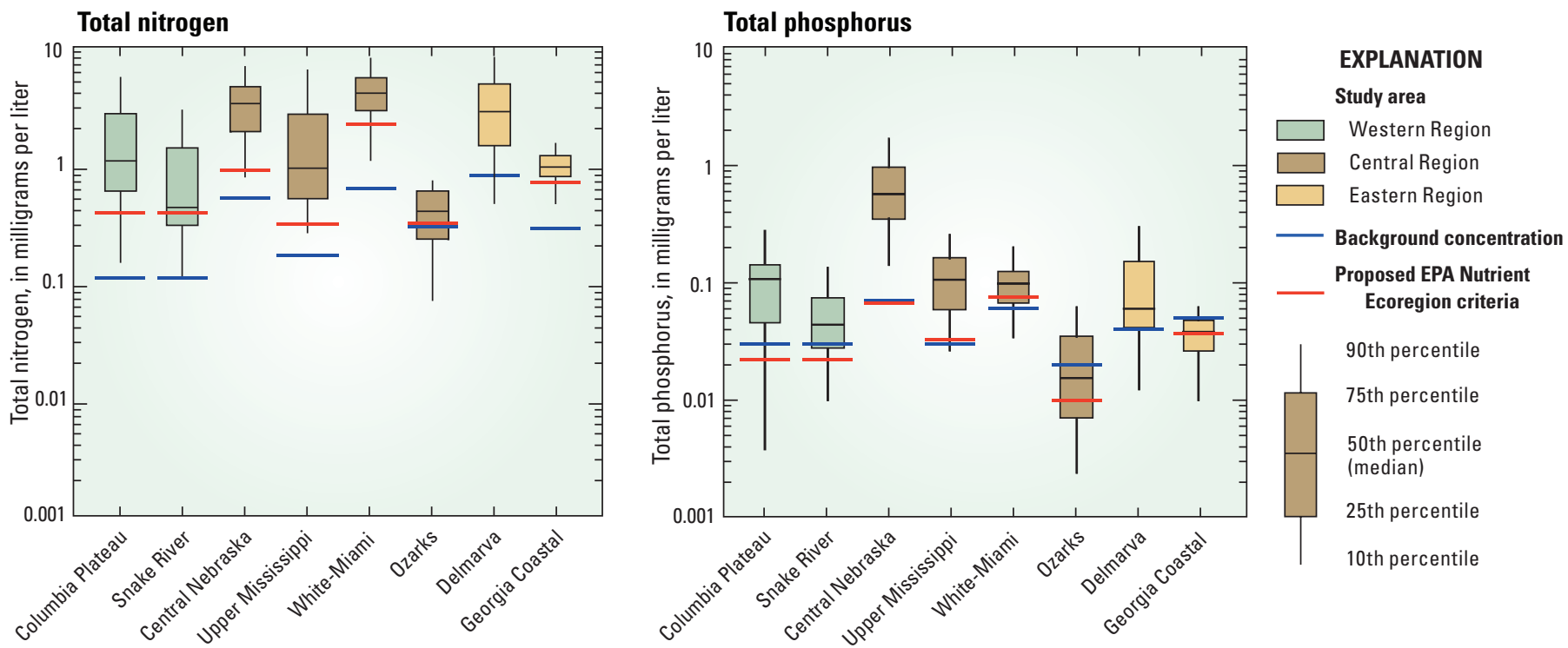

Figure 4-1. Concentrations of total nitrogen and total phosphorus were greater than modeled background concentrations and proposed U.S. Environmental Protection Agency (EPA) regional nutrient criteria (Herlihy and Sifneos, 2008) in most of the eight study areas. There were no proposed EPA nutrient criteria for the Delmarva nutrient ecoregion. 
The high concentrations of total nitrogen and total phosphorus in most of the streams studied reflect the intensity of agricultural practices in these watersheds. A broader study of streams determined that some of the highest concentrations of nutrients in the United States are in agricultural streams, often greatly exceeding modeled background concentrations (Dubrovsky and others, 2010). The high nutrient concentrations in many agricultural watersheds underscore the challenge of reducing nutrients to levels protective of aquatic life in agricultural streams. Although total nitrogen and total phosphorus concentrations varied substantially both within and

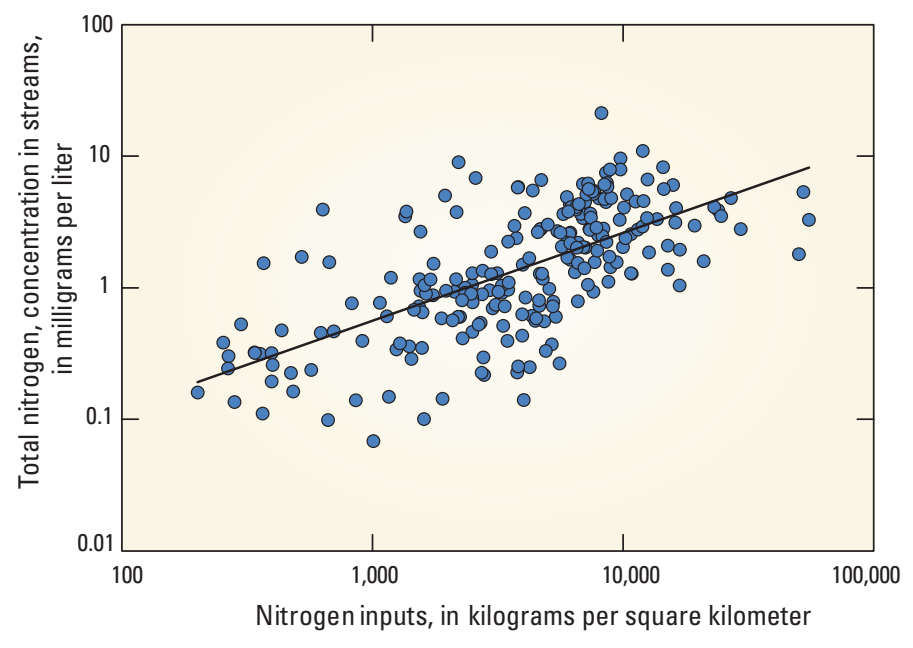

Figure 4-2. Nitrogen inputs to watersheds are correlated with nitrogen concentrations in streams $(r=0.65, P<0.01)$, but the large amount of unexplained variation in nitrogen concentration indicates additional factors also greatly influence nutrient concentrations in agricultural streams. between study areas, total nitrogen and total phosphorus at most sites exceeded the modeled background concentrations (fig. 4.1).

Total nitrogen concentrations were correlated with nitrogen inputs to watersheds ( $\mathrm{r}=0.65$, fig. 4-2); however, total phosphorus concentrations and phosphorus inputs were poorly correlated ( $\mathrm{r}=0.25$, not shown). The relatively weak association of nutrient inputs and instream concentrations is evidence that additional factors, outside of nutrient sources, such as transport pathways and biogeochemical processes, also greatly influence nutrient concentrations in agricultural streams.

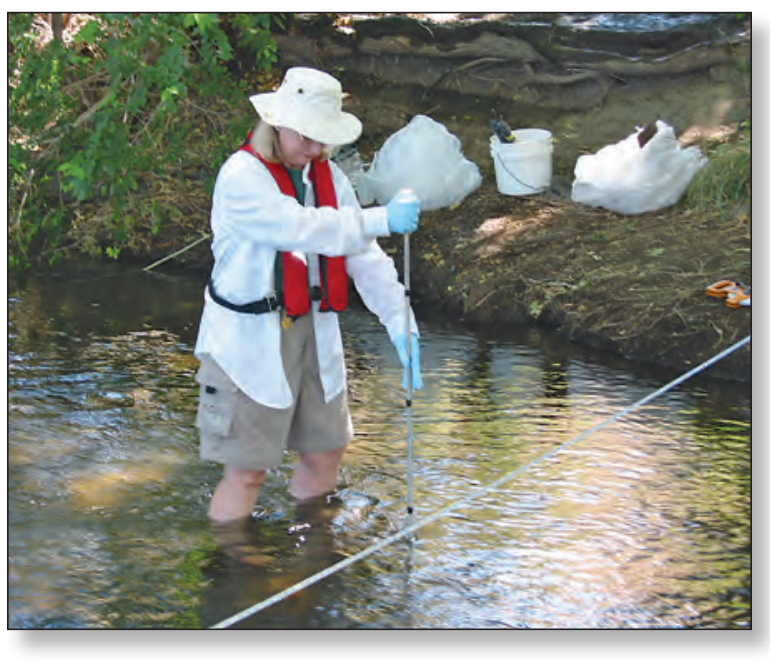

Sampling nutrients in surface waters. Photograph taken by M.D. Munn, U.S. Geological Survey, August 18, 2003.

\section{How Do Nutrient Concentrations in Agricultural Streams Compare to Reference Streams?}

Comparing nutrient concentrations in a study stream to those found in reference streams is a preferred approach to assess stream condition (Herlihy and Sifneos, 2008). However, in many parts of the United States, it is difficult or impossible to find reference streams. In these instances, regression models are used to estimate total nitrogen or total phosphorus "background" concentrations for streams. In these models, the contributions of nutrients from agricultural and urban lands are set to 0 , which produces an estimate of stream nutrient concentrations prior to development. Another method to evaluate the condition of streams is to compare stream nutrient concentrations to those from previous studies at a certain percentile. For example, the proposed EPA nutrient ecoregion criteria used either the 25th percentile of all nutrient data or the 75th percentile of reference sites within a Nutrient Ecoregion to set a criteria to protect stream health (U.S. Environmental Protection Agency, 2000). Both of these methods were used in figure 4-1 to provide context for the nutrient data in this study. 


\section{Role of Hydrologic Flow Paths and Biogeochemical Processes}

Hydrologic flow paths and geochemistry are two main factors that determine the dominant nutrient pathways in a watershed. Hydrology, or how water moves, is an important driver of nutrient transport. Most conceptual models of nutrient transport consider two dominant pathways to streams (fig. 4.3):

- Quick-flow pathways such as overland flow, tiles drains, and near-stream shallow groundwater flow; and

- Slow- or base-flow pathways, primarily groundwater discharge; however, in some instances steady discharge of water from other pathways (for example, tile drains, snow melt) may be included in base-flow estimates.

Streams in watersheds with well-drained soils and permeable aquifer sediments tend to have a greater proportion of streamflow derived from groundwater discharge. Agricultural management practices can hasten the movement of nutrients to streams through artificial drainage (for example, tile drains) or can impede the movement of nutrients through the addition of riparian buffer zones and conservation tillage.

Geochemical conditions and the chemical properties of nutrients themselves also have a major effect on nutrient transport in a watershed. Dissolved forms of nutrients move through either quick-flow or slow-flow pathways. Nitrate is typically detected in the dissolved form. Particulate forms of nutrients move to streams primarily through quick-flow pathways. Orthophosphate often is transported in the particulate form. Nitrogen and phosphorus also respond differently to changes in geochemistry. For example, nitrate removal by denitrification often occurs in groundwater - a slow flow pathway - when dissolved-oxygen concentrations are low (Tesoriero and Puckett, 2011). Conversely, orthophosphate, which is commonly bound to sediments by iron oxides, may be released into the stream or aquifer if the concentrations of dissolved oxygen become low enough to dissolve iron oxides (Miller and others, 2001). As a result, high concentrations of dissolved oxygen favor transport of nitrate in groundwater to streams, but often limit orthophosphate transport.

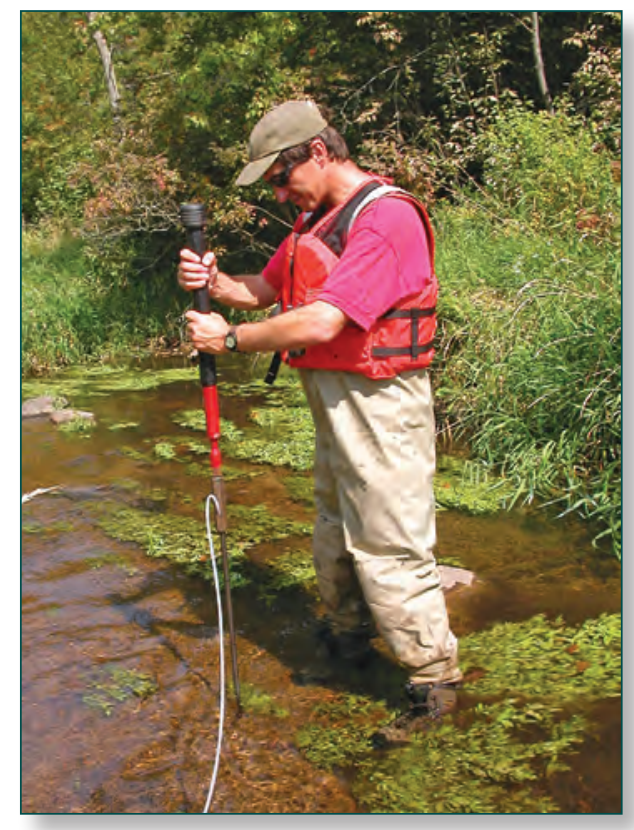

Sampling nutrients below streambed. Photograph taken by Paul Juckem, U.S. Geological Survey.

Figure 4-3. Nutrient pathways to streams depend on many natural factors (such as soil and aquifer permeability and slope of land) and anthropogenic factors (drainage systems and best management practices). Adapted from Tesoriero and others (2013).

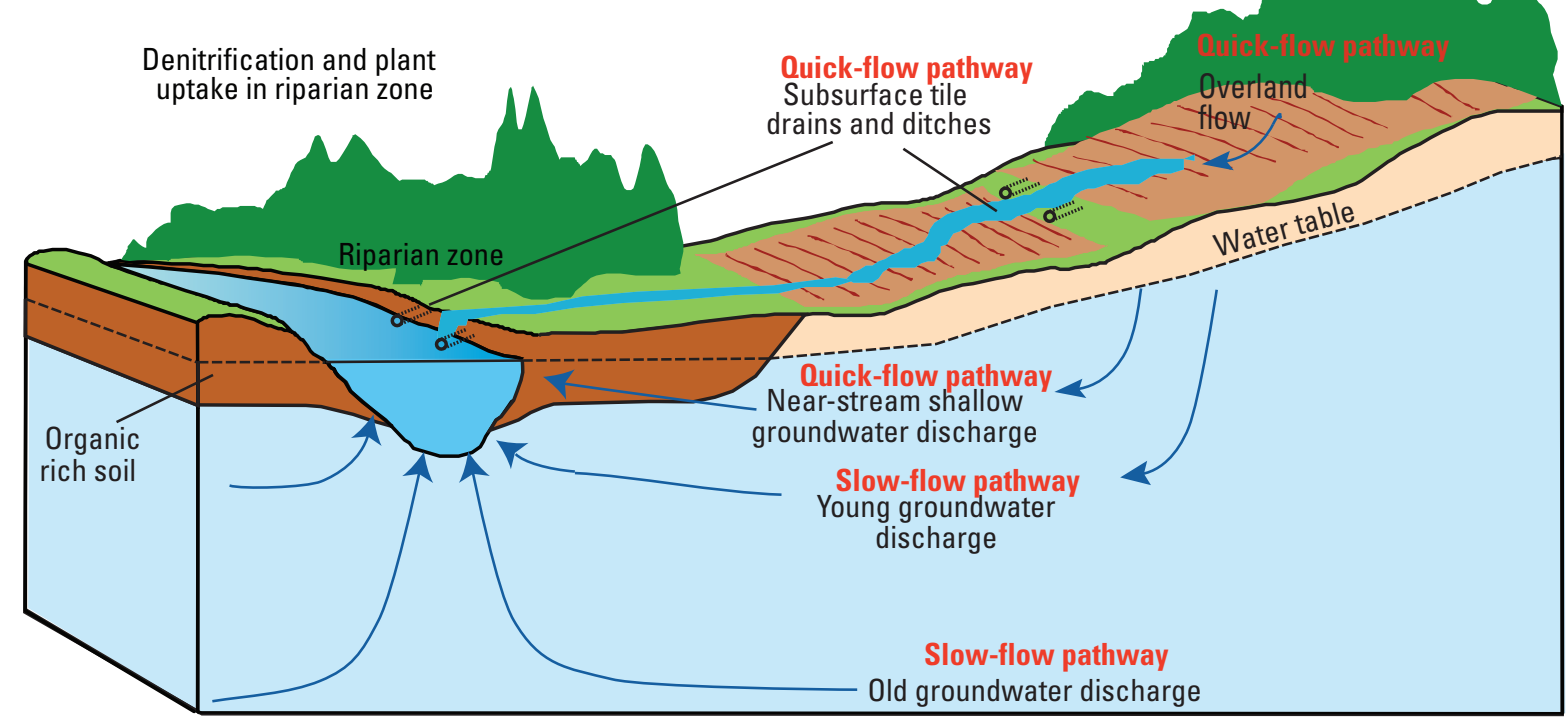




\section{Hydrologic Pathways Differ Across Environmental Settings}

Regional patterns of base flow suggest that most of the streamflow in much of the upper Midwest and West is derived from groundwater, whereas much of the streamflow in the Corn Belt States (for example, Indiana, Illinois, and Iowa) is derived from quick flow (Wolock 2003; Santhi and others, 2008). Estimates of base-flow index (BFI) across the Nation allow for a regional understanding of likely nutrient pathways to streams (fig. 4.4A) (see "Estimation of the Base-Flow Index"). Of the eight study areas (232 sites) examined in this study, BFI values were high for the Columbia Plateau, Snake River, Upper Mississippi, and Delmarva, suggesting slow transport by groundwater as the primary flow path (fig. 4.4B). Conversely, BFI values were low for three of the remaining four study areas (Central Nebraska, Ozarks, and WhiteMiami) indicating that quick-flow pathways are dominant. Overland flow and subsurface drainage (tile drains) are the primary quick-flow pathways; groundwater transport through karst terrain in the Ozarks also may be a quick-flow pathway. Understanding the primary nutrient transport pathway in the various watersheds enables managers to emphasize the most effective strategies to reduce nutrient transport to streams. Detailed studies were conducted at seven sites to evaluate the pathways of nutrients to streams. Studies were conducted at one site each in the Delmarva, Central Nebraska, Upper Mississippi, White-Miami, and Columbia Plateau study areas (fig. 4-4A). Two additional sites were selected in Wisconsin and North Carolina to provide a broader range in geochemical and hydrologic conditions (fig. 4-4A).
Groundwater commonly is a predominant pathway for nitrate transport to study streams, but not for orthophosphate transport to streams.

In this study, groundwater is the dominant source of the annual nitrate load in streams when at least 40 percent of streamflow is derived from groundwater (fig. 4-6; Tesoriero and others, 2009, 2013). In contrast, groundwater typically is only a minor contributor of the annual orthophosphate load in these streams (fig. 4-6; Tesoriero and others, 2009). Groundwater pathways to streams range from tile drains at the poorly drained, low BFI site (Sandy Run, North Carolina), shallow groundwater flow paths through the riparian buffer at the moderate BFI site (Morgan Creek, Maryland), and through the streambed at the well-drained high BFI site (Tomorrow River, Wisconsin).

Nutrient pathways to streams were further examined by relating nutrient concentrations in streams to the proportion of streamflow derived from groundwater - as indicated by the BFI values calculated for each nutrient sample collection time (fig. 4-7). Nitrate concentrations in Sandy Run decrease as the BFI values increase, indicating transport by quick-flow pathways - overland flow and tile drainage (fig. 4-7A.1 and A.2; Tesoriero and others, 2013). In contrast, a groundwater source of nitrate is indicated at the Tomorrow River site as stream nitrate concentrations increased as base flow increased; concentrations were lower at low BFI values due to dilution by low-nitrate surface-water runoff (fig. 4-7B.1 and B.2). A groundwater source of nitrate at this site is further supported by the similarity between instream concentrations during high base-flow periods and those in groundwater beneath adjacent agricultural areas (Tesoriero and others, 2013). 

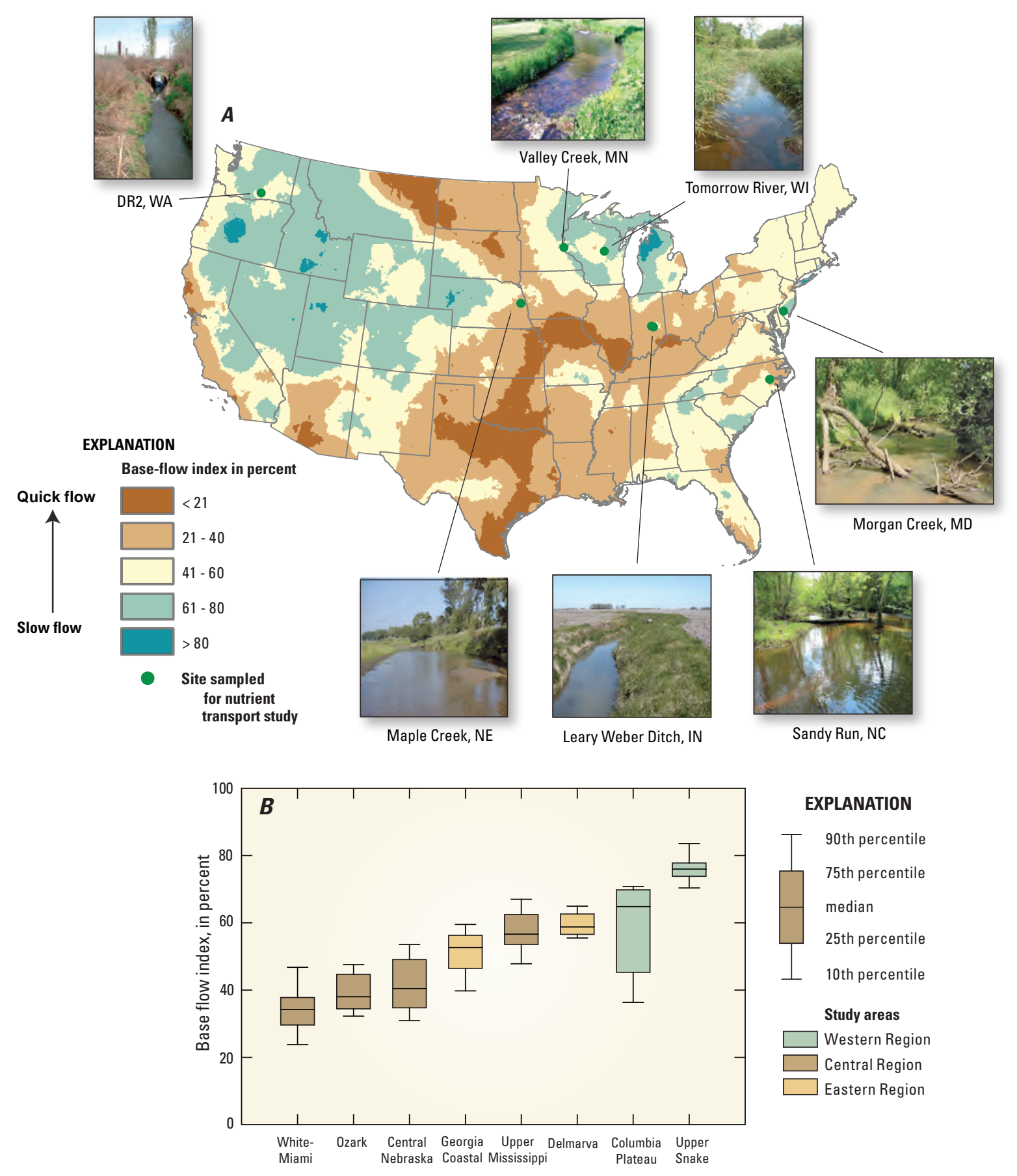

Figure 4-4. Streams in watersheds with well-drained soils and permeable aquifer sediments tend to have a greater proportion of streamflow derived from groundwater discharge. The base-flow index (BFI) is the ratio of base-flow volume to the total-flow volume for a given time period. (A) Annual base-flow index values estimated for the United States allow for a regional understanding of likely nutrient pathways to streams (Wolock, 2003). (B) High annual BFI values - such as those in the Columbia Plateau study area of the Western Region suggest that slow groundwater flow paths supply most streamflow; low values - such as those in the White-Miami study area of the Central Regionsuggest that quick flow, such as overland flow and tile drains, supply most streamflow. 


\section{Estimation of the Base-Flow Index}

Base flow is the component of streamflow that is largely unaffected by flow induced by recent precipitation events (quick flow) and often can be attributed to groundwater discharge into streams (fig. 4.5). The base-flow index (BFI) is the ratio of base flow to total flow, expressed as a percentage. The BFI can be calculated for an individual point in time to reflect the specific flow conditions at that moment (see fig. 4.7); or cumulatively for a specified time period (for example, annual values [fig. 4.4]).

Annual BFI values were estimated for small streams in the United States using stream discharge data for more than 19,000 USGS streamgages (Wolock, 2003). Annual BFI values at each streamgage were computed using an automated hydrograph separation computer program called the BFI program (Wahl and Wahl, 1988, 1995). The BFI map (fig. 4.4A) was interpolated from the BFI values estimated at each streamgage (data and additional methods are provided in U.S. Geological Survey, 2014).

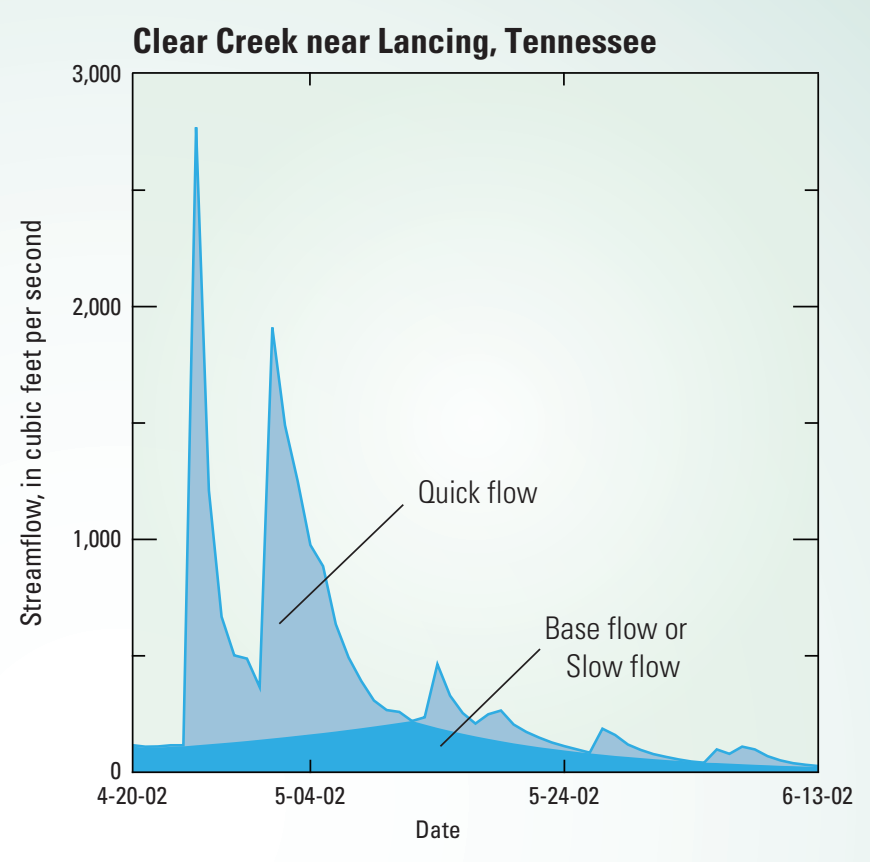

Figure 4-5. Streamflow hydrograph shows the estimated partitioning of total flow into base or slow flow and quick-flow components for the National Water-Quality Assessment site, Clear Creek near Lancing, Tennessee (from Dubrovsky and others, 2010). The quick-flow components are associated with runoff from storms or irrigation, whereas groundwater typically dominates during the slow flow periods. 


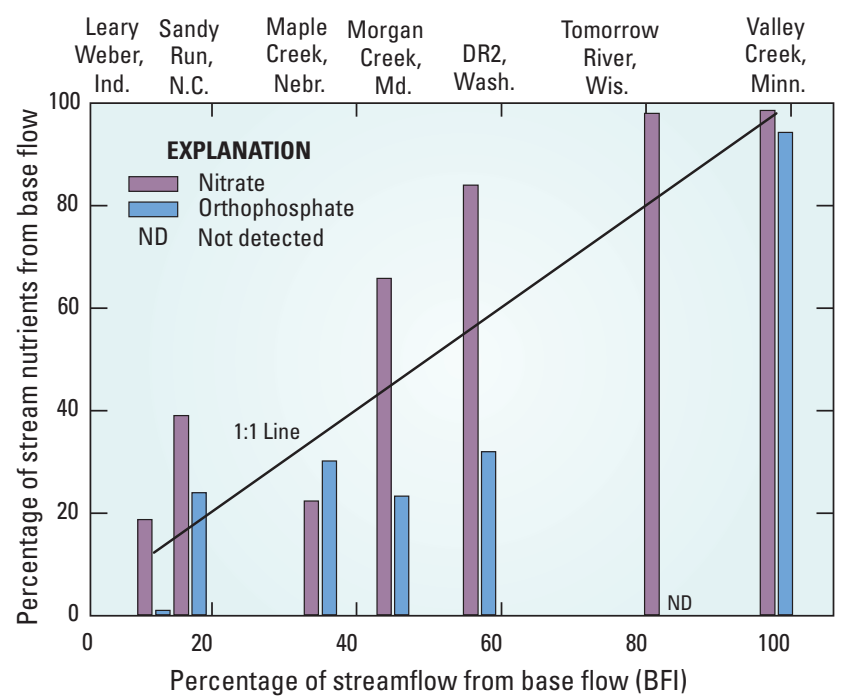

Most of the orthophosphate in streams in these detailed studies was transported to streams through quick-flow pathways, such as overland flow. For example, orthophosphate concentrations in Morgan Creek decrease as the amount of base flow increases (fig. 4-7A.3), indicating a quick-flow source. Orthophosphate concentrations in upland groundwater are typically lower than in streams, further evidence that groundwater is not a significant source of orthophosphate concentrations in most streams (Tesoriero and others, 2009).

When geochemical conditions are favorable, groundwater transport of orthophosphate to streams can be significant.

Although the groundwater contribution of orthophosphate to streams is often small, natural and agricultural sources of phosphorus can result in high orthophosphate concentrations in groundwater (Holman and others, 2010). Favorable
Figure 4-6. The higher percentage of nitrate from base flow relative to the amount of streamflow from base flow (bars that extend above 1:1 line) suggests that groundwater discharge often is a preferred pathway for nitrate transport to streams. Conversely, the lower percentage of orthophosphate from base flow relative to the amount of streamflow from base flow (below 1:1 line) suggests that groundwater discharge is usually not a preferred pathway for orthophosphate transport to streams. geochemical conditions in groundwater - low dissolved oxygen, high sulfate and silica-may explain the groundwater input of orthophosphate to Maple Creek during high base-flow conditions (fig. 4-7B.3). High orthophosphate concentrations in upland groundwater and during base flow in streams in the Maple Creek watershed indicate that groundwater pathways are an important source of orthophosphate to this stream (Tesoriero and others, 2009). As a result, management changes that limit only orthophosphate transport along quickflow pathways may not sufficiently affect orthophosphate concentrations in this stream. In fact, high orthophosphate concentrations $(>0.10 \mathrm{mg} / \mathrm{L})$ in groundwater discharging to streams in this area (Burkart and others, 2004) may prevent streams from meeting the EPA-recommended total phosphorus criteria $(0.076 \mathrm{mg} / \mathrm{L}$; Ecoregion VI, Corn Belt and Northern Great Plains, Herlihy and Sifneos, 2008). 
Quick-flow pathways

\section{Hydrologic pathways}

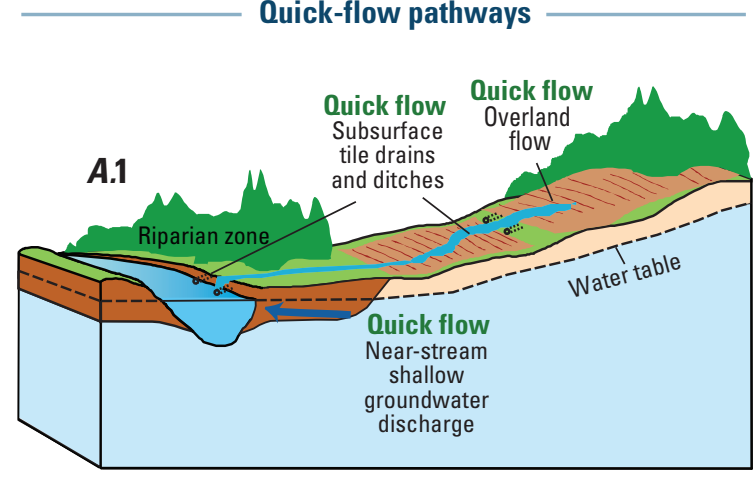

\section{A.2 Sandy Run, North Carolina}

Nitrate
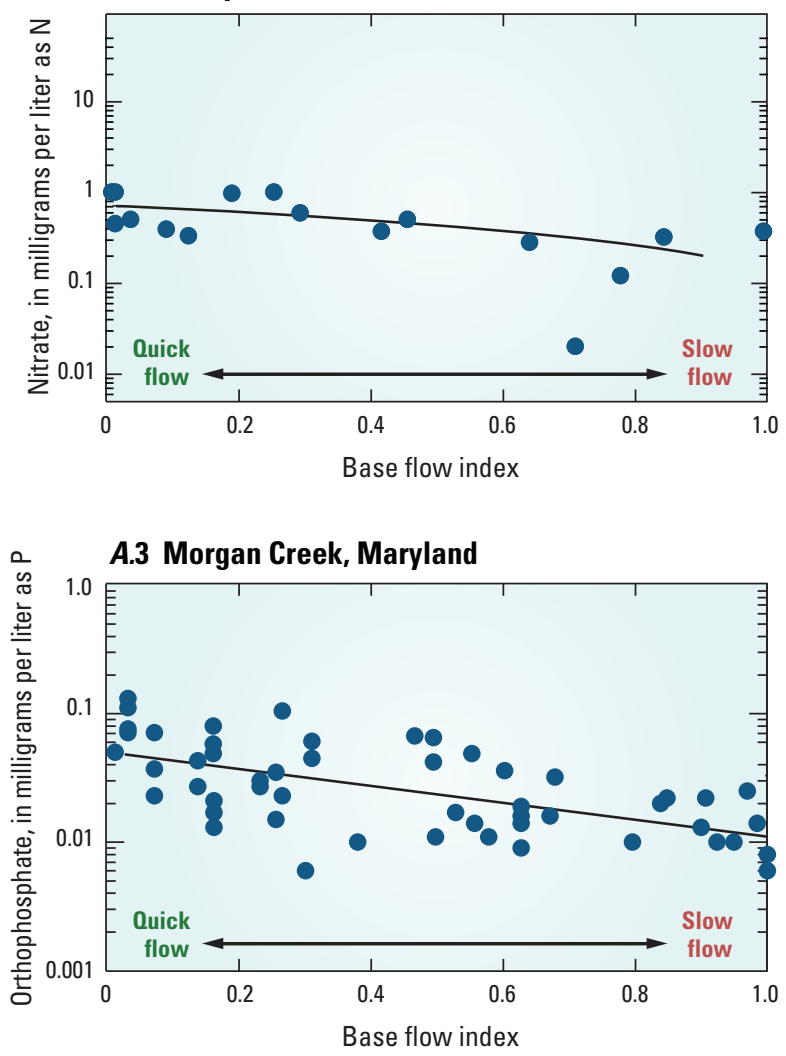

Slow-flow pathways

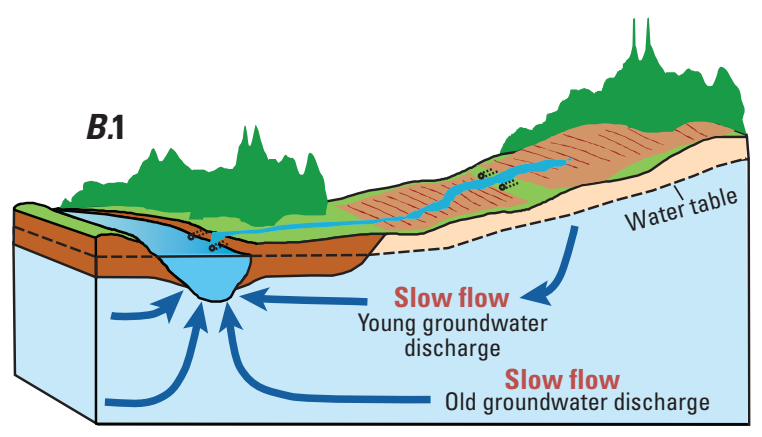

B.2 Tomorrow River, Wisconsin
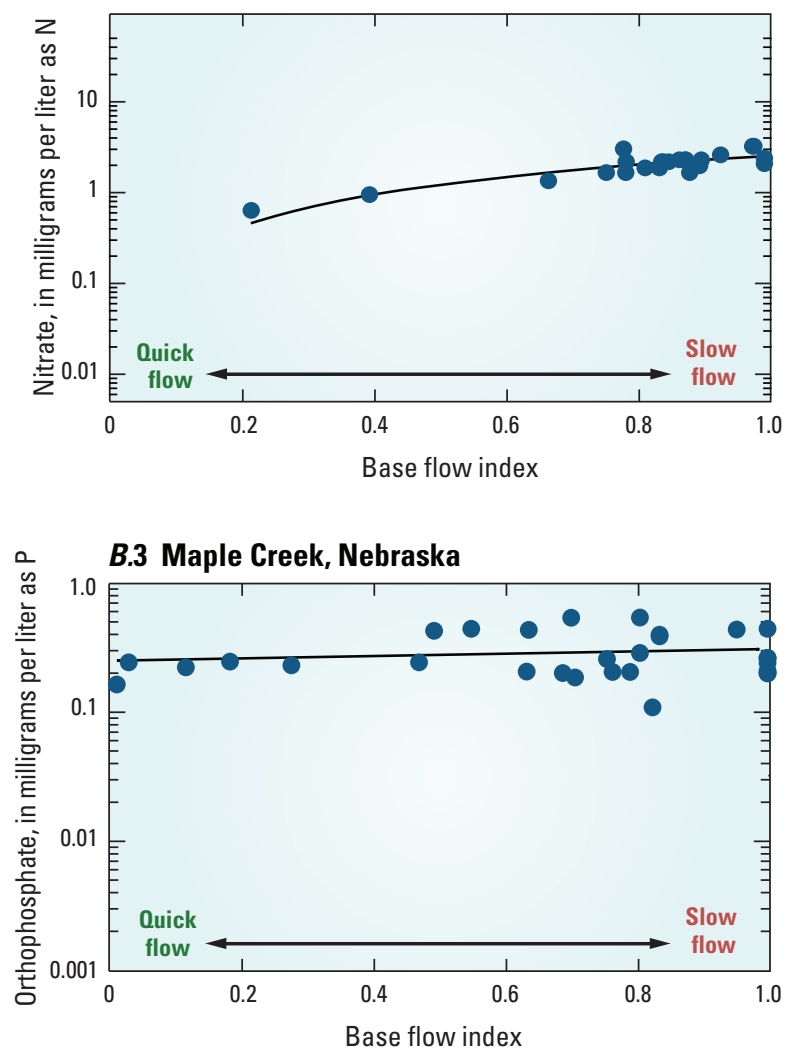

Figure 4-7. Nutrient pathways to streams vary depending on the local hydrology and geochemical conditions $(A .1, B .1)$. A groundwater source of nitrate is indicated when nitrate concentrations in streams increase as the proportion of base flow increases (Tomorrow River, B.2) and approaches values observed in groundwater (data not shown). The higher nitrate concentrations when base-flow index values are low for Sandy Run (A.2) show that nitrate also may be transported to streams through quick-flow pathways, like tile drains (A.1). In contrast to nitrate, orthophosphate transport is predominantly by quick-flow pathways, as indicated by the decrease in orthophosphate concentrations as the proportion of streamflow from base flow increases (Morgan Creek, A.3). However, groundwater can contribute orthophosphate to streams if biogeochemical conditions are favorable (Maple Creek, B.3); orthophosphate in this stream is derived from both quick-flow paths and groundwater sources, as indicated by the relatively constant orthophosphate concentrations in the stream and high orthophosphate concentrations in groundwater (Tesoriero and others, 2009). 


\section{Influence of Instream and Near-Stream Processes on Nitrogen Concentrations in Agricultural Streams}

Natural streams have processes that remove nitrate from stream water, primarily by plant uptake and denitrification. These streams are complex, with pools, riffles, and backwaters, which slow water down, increasing the time available for these processes. In particular, stream water that is directed into the streambed - the hyporheic zone- before returning to the channel has greater opportunities for nitrogen removal by denitrification due to the relatively slow movement through the sediments. In contrast, human modifications of agricultural streams and ditches have altered the stream structure in many cases, decreasing stream complexity. Less complexity results in water moving more rapidly down a stream, reducing the time available for processing and hence nitrate removal. This can result in streams losing the natural ability to transform and remove nitrogen from the system; less removal results in larger nutrient loads delivered to downstream receiving waters.
Limited contact time for nitrate in stream water to interact with aquatic vegetation and bacteria suggests little opportunity for uptake or denitrification in agricultural streams.

An important metric that affects nutrient processing is transient storage, which is the temporary retention of water in streams either within the channel or in sediments beneath and adjacent to the channel in the hyporheic zone. Because transient storage increases the residence time of water in the stream reach, it can increase the amount of time that stream water interacts with biota, resulting in an increase in denitrification (Mulholland and others, 2009). Results from a transport model constructed for this study suggest that the amount of time stream water spends in transient storage is less than in agricultural streams in previous studies and much lower than in natural reference streams (fig. 4-8; Sheibley and others, 2014 and references therein). In fact, the average nitrate molecule in streams analyzed for this study spends less than 1 percent of its time in storage, limiting the amount of denitrification and uptake that can occur (Sheibley and others, 2014). Stream gradients were lower at these study sites than streams in previous studies, which may partly explain the lower transient storage in the agricultural streams in this study. Results of this study suggest that once in the stream, nitrate is largely transported downstream in these agricultural watersheds.
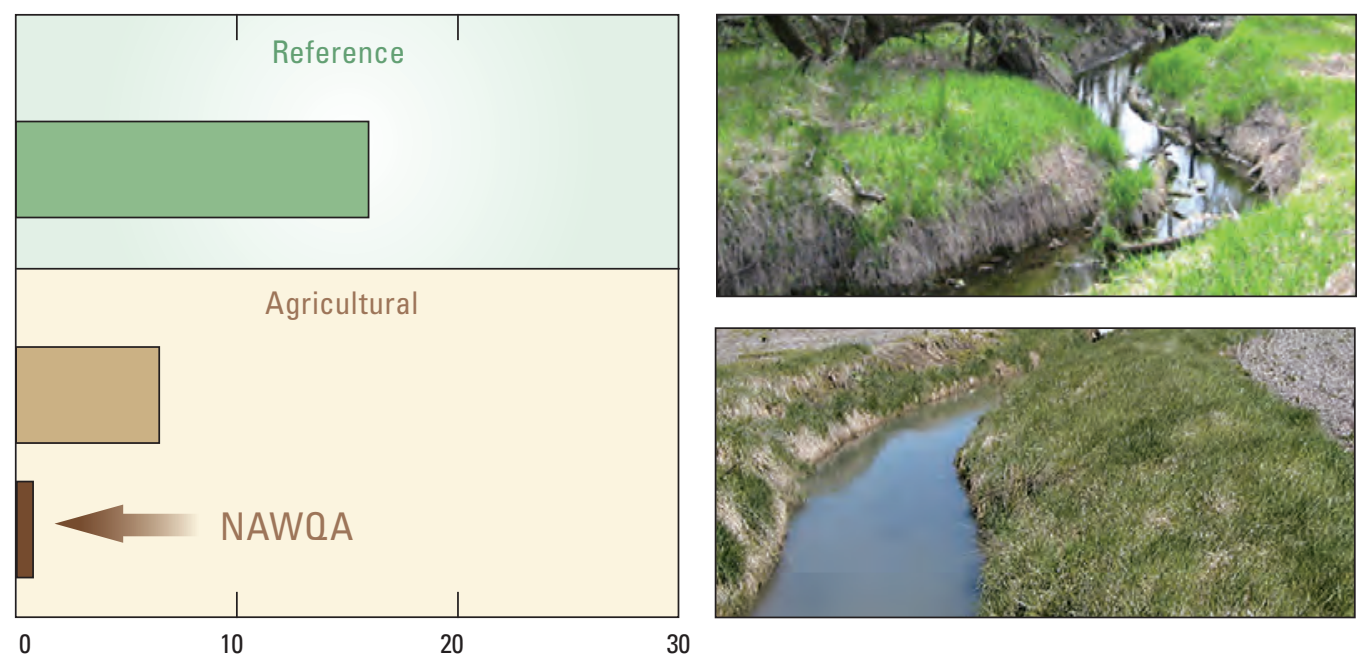

Average transient storage $\left(\mathrm{F}_{\text {med }}\right)$, as a percent of time water is in storage

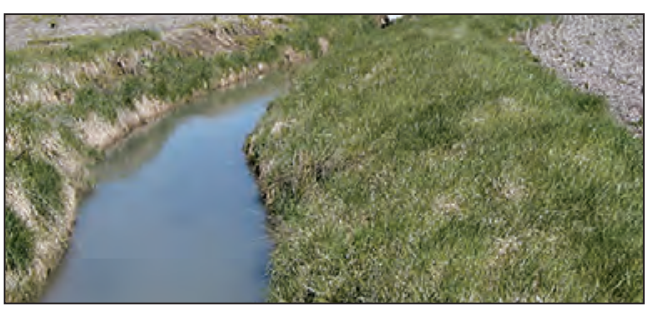

Figure 4-8. Transient storage - the temporary retention of water either within the stream channel or adjacent bank or bed sediments - is low in the agricultural streams examined in this study compared to agricultural and reference streams for multiple studies (Mulholland and others, 2008; Sheibley and others, 2014). Low transient storage results in little contact time between stream water and bank and bed sediments, diminishing both denitrification and the uptake of nitrate. As a consequence, more nitrate will be exported downstream. 
Nitrate loads in study reaches increase because groundwater inputs are larger than nitrate removal by uptake and denitrification.

Reach-scale nitrate mass balance calculations were made at seven stream sites to determine whether the stream reach was gaining or losing nitrate. Nitrate mass balances were calculated from measurements of the upstream, groundwater, and downstream loads. The difference between the inputs (upstream and groundwater loads) and the outputs (downstream loads) provide an estimate of the amount of nitrate retention (nitrification, uptake by aquatic vegetation, and denitrification) that has occurred in the reach (Tomorrow River example, fig. 4.9).

Nitrate loads increased along the study reach at each of the seven study sites indicating that nitrate inputs from groundwater were greater than nitrate retained within the reach (Sheibley and others, 2014). Groundwater nitrate loads to streams were substantially offset by loss processes at two sites (more than 50 percent groundwater nitrate input retained) and minimally offset (less than 5 percent of groundwater nitrate input retained) at four others. The low transient storage in these streams suggests that these loss processes do not occur primarily instream but rather in groundwater prior to discharge. These studies were conducted during summer base-flow conditions when retention within the reach is likely to be higher than other times of the year; higher temperatures in summer likely result in higher rates of gross primary production and denitrification than during other times of the year.

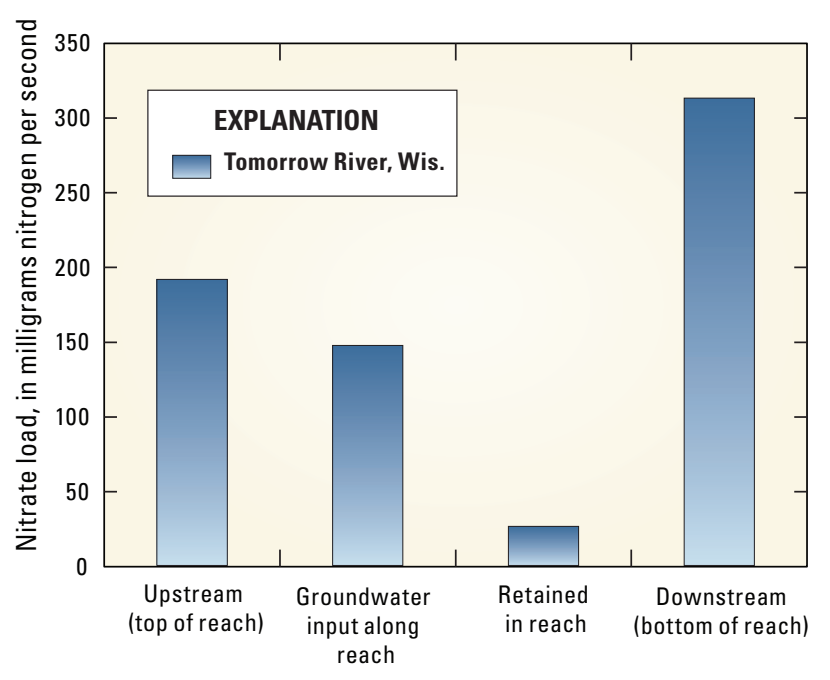

Figure 4-9. Nitrate loads increase along the study reach in the Tomorrow River (Wisconsin) because nitrate retained in the reach by denitrification and uptake is not sufficient to offset groundwater inputs of nitrate (Sheibley and others, 2014).

\section{Influence of Historical Nutrient Inputs}

Groundwater can be an important source of nitrate to streams long after source controls are implemented at the land surface.

Decades of recharge of high-nitrate groundwater have created a legacy — a mass of high-nitrate groundwaterthat has implications for future nitrate concentrations in streams (fig. 4-10). Nationally, inorganic nitrogen fertilizer applications to the land surface have increased 10-fold since 1950 (Ruddy and others, 2006) resulting in sharp increases in nitrate concentrations in recharging groundwater (Puckett and others, 2011). Stream vulnerability to legacy nitrate is expected to increase as the amount of streamflow that is derived from groundwater increases (Tesoriero and others, 2013). However, biogeochemical processes may reduce the vulnerability of streams to legacy nitrate if nitrate in groundwater is removed by denitrification (Tesoriero and Puckett, 2011). Legacy groundwater sources of orthophosphate typically are not substantial because orthophosphate concentrations in groundwater are usually low (Dubrovsky and others, 2010); however, legacy groundwater sources of orthophosphate may be important in select settings (for example, Central Nebraska; Tesoriero and others, 2009; Domagalski and Johnson, 2011).

A groundwater-surface water interaction study was conducted at a groundwater-dominated stream to evaluate the effect that legacy nitrate has on stream nitrate concentrations. This study was conducted at the Tomorrow River in central Wisconsin, a stream that receives approximately 80 percent of annual streamflow from groundwater. Concentrations of dissolved oxygen typically are high in upland groundwater and the streambed at this site. The presence of dissolved oxygen limits denitrification, thus allowing for the migration of nitrate in groundwater and subsequent discharge to this stream. As a result, it is estimated that more than 95 percent of the nitrate in this stream is derived from groundwater (Tesoriero and others, 2013). Groundwater discharging to the Tomorrow River has an average age of 27 years, based on the concentrations of environmental tracers in these waters. When nitrate in groundwater has a long travel time before discharging to a stream, the full effect of management strategies designed to reduce nitrate concentrations in a stream may not be measurable for decades (fig. 4-10). 


\section{A. 2009-Agricultural watershed}
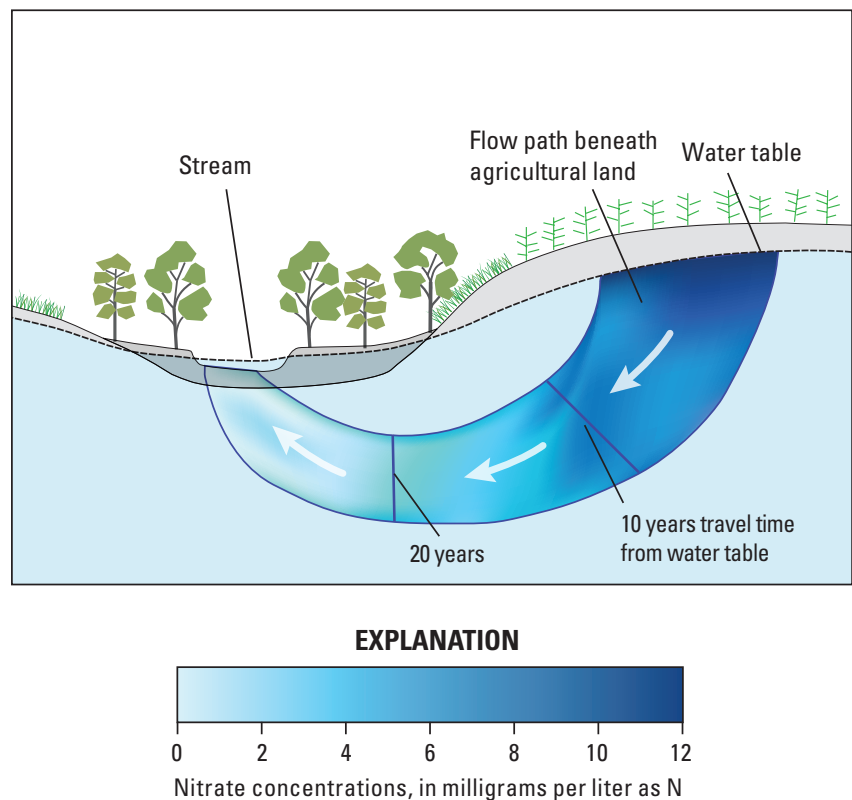

Soil and sediment are important reservoirs of bound phosphorus that can be released to streams in the future.

Most regulatory nutrient work focuses on nutrients in the water column; however, soils and sediment can be an important reservoir of nutrients, particularly phosphorus. Some phosphorus applied to crops is not taken up by plants, but instead becomes bound to the surface of soil particles and stored. This sediment-bound phosphorus can either (1) remain in place; (2) remobilize and leach to groundwater; (3) erode and be temporarily stored in ditches, settling ponds, or other sediment-control structures; or (4) erode and be deposited in streams. Once in the stream, this bound phosphorus can be released from storage and become available for plant growth under appropriate geochemical conditions in the future. The release of bound phosphorus accumulated from past agricultural practices is believed to be one reason why best management practices known to reduce phosphorus transport off of fields have not always resulted in improvement of instream water quality and (or) biological conditions (Meals and others, 2010; Kleinman and others, 2011; Sharpley and others, 2013). Expectations for future improvements in the biological condition of streams as a result of improved phosphorus control in agricultural landscapes may need to consider the quantity and timescales of phosphorus release from storage (Jarvie and others, 2013; Sharpley and others, 2013).

\section{B. 2029-Agricultural practices changed to fallow lands}

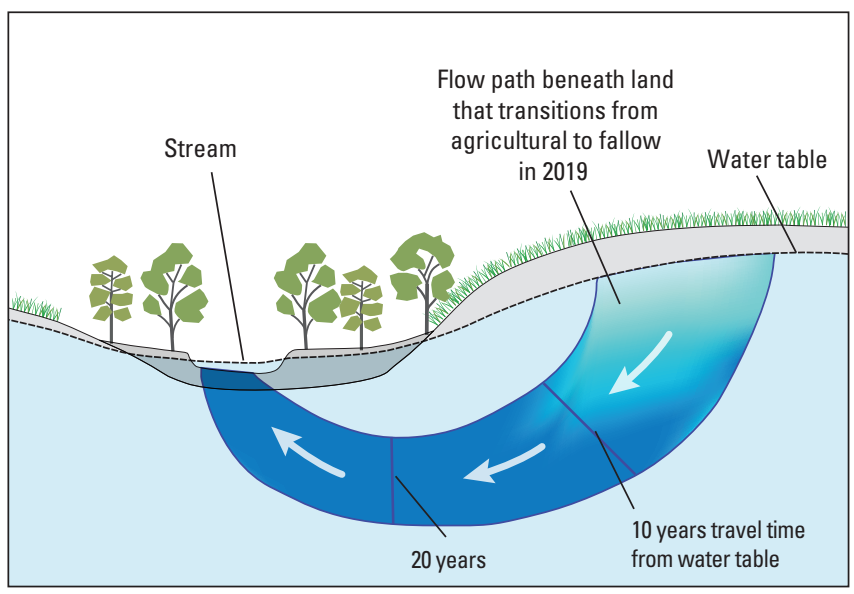

Figure 4-10. Legacy effects on nitrate concentrations in a hypothetical stream (based on Tomorrow River, Tesoriero and others, 2013). High nitrate concentrations in groundwater underlying agricultural lands in $2009(A)$ can increase nitrate concentrations in streams in the future $(B)$. Groundwater discharging to this stream in 2029 along this flow path will have higher nitrate concentrations than groundwater that discharged to this stream in 2009, potentially causing stream nitrate concentrations to increase $(B)$. As a result of these legacy nitrate sources, benefits from the implementation of best management practices to control the transport of nutrients to streams may not be observed for decades in these systems $(B)$. Although reducing nitrate sources, for example, by fallowing fields $(B)$ may result in low nitrate concentrations in shallow groundwater within a few years, this low nitrate groundwater must travel for decades before reaching the stream.

Findings from one aspect of this study illustrate the potential effect of phosphorus release from storage. Aquatic macrophyte biomass in the Snake River had little or no relation to total phosphorus measured in water, but there was a strong relation between macrophyte biomass and loosely sorbed phosphorus concentrations in sediments on the streambed (Simon and others, 2009; Mebane and others, 2013; see Chapter 5). Other studies also have determined that aquatic plants obtain most of their phosphorus requirements from sediments, not water. This results in aquatic plant productivity being disconnected from phosphorus in water (Carignan and Kalff, 1980; Chambers and others, 1989). Thus, even if management measures are successful at reducing the phosphorus concentrations in the water through source reduction, rooted aquatic plants may still get adequate nutrition from sediments until this source is depleted. 



\section{Conceptual Model of Aquatic Vegetation in Agricultural Streams}

Early studies of nutrients and algal biomass were focused on lakes, with results indicating that nutrients were strong predictors of algae in the water column (Sakamoto, 1966; Edmondson, 1972). These findings initially carried over into stream ecology; however, it was quickly discovered that nutrients are not necessarily good predictors of algal production primarily due to interactions of nutrients, temperature, $\mathrm{pH}$, light, streamflow, and grazing by invertebrates and fish (Pringle and Bowers, 1984; Pringle, 1987; Corkum, 1996). Therefore, many studies addressing nutrient-algal biomass relations in streams show high variability and are thus presumed to be of limited use for decision making.

The Nutrient-Algal Biomass Conceptual Model (Munn and others, 2010) presents an alternative way of understanding the "noise" in these relations. Increasing the concentrations of nitrogen or phosphorus in streams can result in an increase in benthic algae (fig. 5-1). However, there is a great deal of variability in nutrient-biomass relations partly due to a combination of habitat and biological processes. For example, when algal biomass becomes high, biological uptake reduces nutrient concentrations (fig. 5-1, upper left quadrant). If nutrient concentrations alone are used for assessing stream condition, then a stream could be classified as satisfying water-quality criteria even though there is an extensive quantity of algae. In contrast, when habitat is limiting (for example, reduced light) algae cannot grow, therefore, there is low nutrient uptake and high nutrient concentrations (fig. 5-1, lower right quadrant). Sites in this quadrant may exceed nutrient concentrations of concern, but have low biomass due to light limitation. These streams may not reflect local biological impairment, but are important sources of nutrients to downstream receiving waters. In order to understand the influence of nutrients on aquatic vegetation, it is important to measure the occurrence of aquatic vegetation, relate levels of aquatic vegetation to nutrients, and consider the relative influence of stream habitat on these relations.

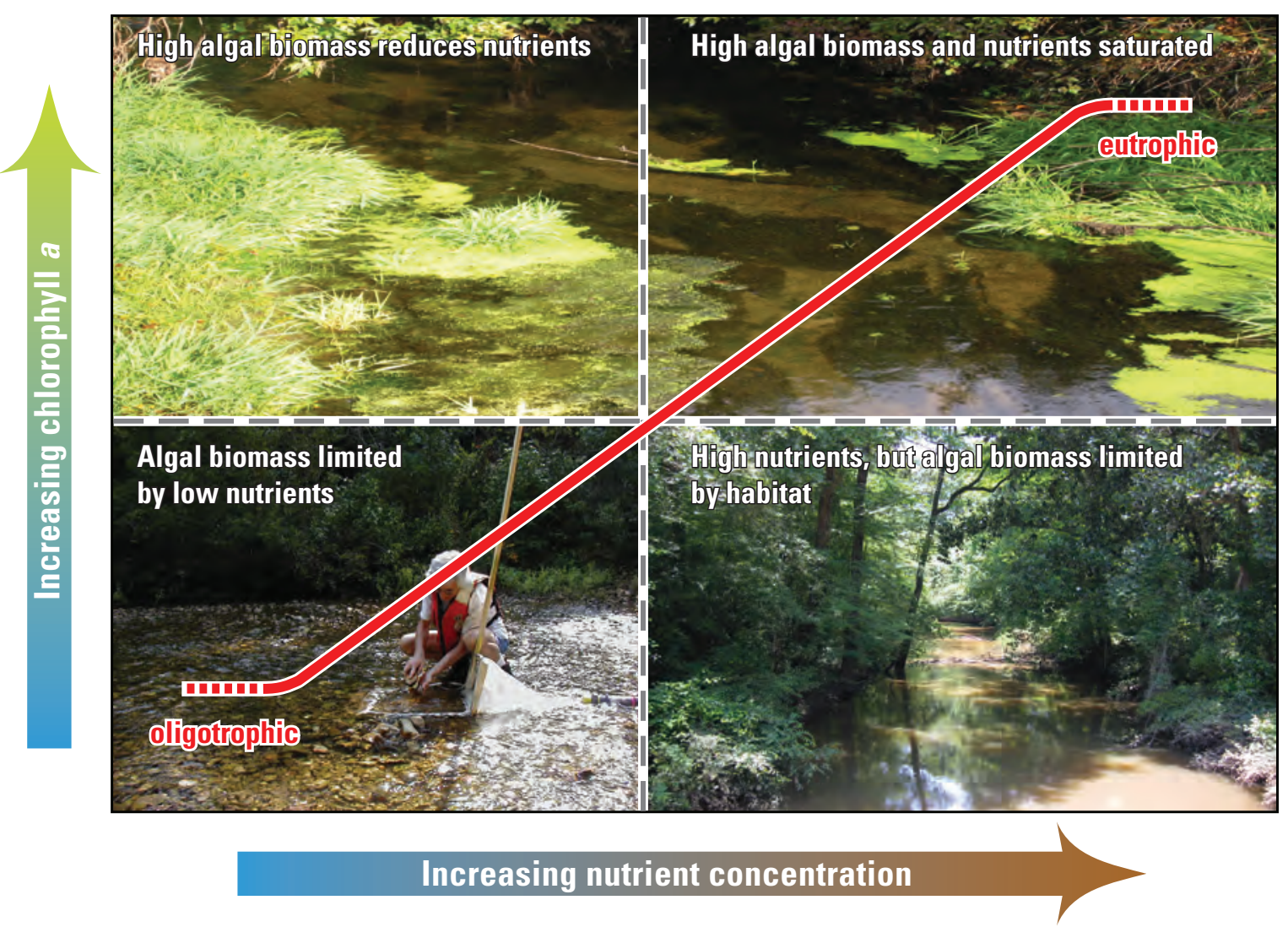

Figure 5-1. The Nutrient-Algal Biomass Conceptual Model illustrates the complex interactions that often lead to weak relations between nutrients and algal biomass (represented by chlorophyll a). The solid line represents the expected linear response of algal biomass to increasing nutrient concentrations. Streams fall into one of the four quadrants depending on the interaction of nutrients, habitat, and algal biomass. Oligotrophic refers to a condition where there is a deficiency of nutrients and low production of algae, whereas eutrophic refers to a system that becomes enriched in nutrients resulting in substantial production of algae. 


\section{Aquatic Vegetation in Agricultural Streams}

Nuisance levels of aquatic vegetation (algae and aquatic plants) is a primary problem associated with increased nutrient input to streams. The amount of aquatic vegetation in agricultural streams can range from a sparse coating on the stream bottom to extensive mats of filamentous green algae (Cladophora) or submerged vascular plants, such as pondweed (Potamogeton spp.). Measuring aquatic vegetation can be done using several approaches, but generally can be divided into quantity (or biomass) of aquatic vegetation or community composition.

\section{Benthic Algal Biomass}

Benthic algal biomass exceeded levels of concern at 13 percent of streams assessed.

The amount of algal biomass in streams spans four orders of magnitude, from 0.1 to $1,000 \mathrm{mg}$ chlorophyll $\mathrm{a} / \mathrm{m}^{2}$ (Stevenson, 1996). Although there are no national regulatory levels of algal biomass, algal biomass greater than $100 \mathrm{mg}$ chlorophyll $a / \mathrm{m}^{2}$ is considered a recreational and aesthetic nuisance (Horner and others, 1983; Welch and others, 1989). Algal biomass collected during the summer growing season for all sites ranged from 0.9 to $273 \mathrm{mg} / \mathrm{m}^{2}$ with a median of $33 \mathrm{mg} / \mathrm{m}^{2}$. Median algal biomass for the Western and
Central Regions were similar, ranging from 31 to $48 \mathrm{mg} / \mathrm{m}^{2}$, whereas the median algal biomass for the Georgia Coastal and Delmarva in the Eastern Region were substantially lower at 5 to $7 \mathrm{mg} / \mathrm{m}^{2}$, respectively (fig. $5-2 A$ ). Nuisance algal levels were most common in the Central Nebraska, where 29 percent of sites exceeded $100 \mathrm{mg} / \mathrm{m}^{2}$ (fig. 5-2A). Regional differences primarily are due to nutrient concentrations and habitat characteristics that limit light, both of which are major control factors for photosynthesis. It is important to note that algal biomass alone does not always fully represent nuisance growth of aquatic vegetation.

\section{Aquatic Macrophyte Cover}

Aquatic macrophyte cover exceeded the 40 percent benchmark level at 10 percent of the sites.

Macrophytes can be the dominant form of aquatic vegetation in some systems and should be included in nutrient monitoring programs. Some agricultural streams are dominated by aquatic macrophytes, which include large filamentous green algae, such as Cladophora, along with aquatic vascular plants, such as the pondweed Potamogeton. Macrophyte cover was highly variable ranging from 0 to 91 percent cover among all sites; however, study area medians ranged from 0 to 21 percent cover (fig. 5-2B). Like algal biomass, there are presently no standards for "acceptable"

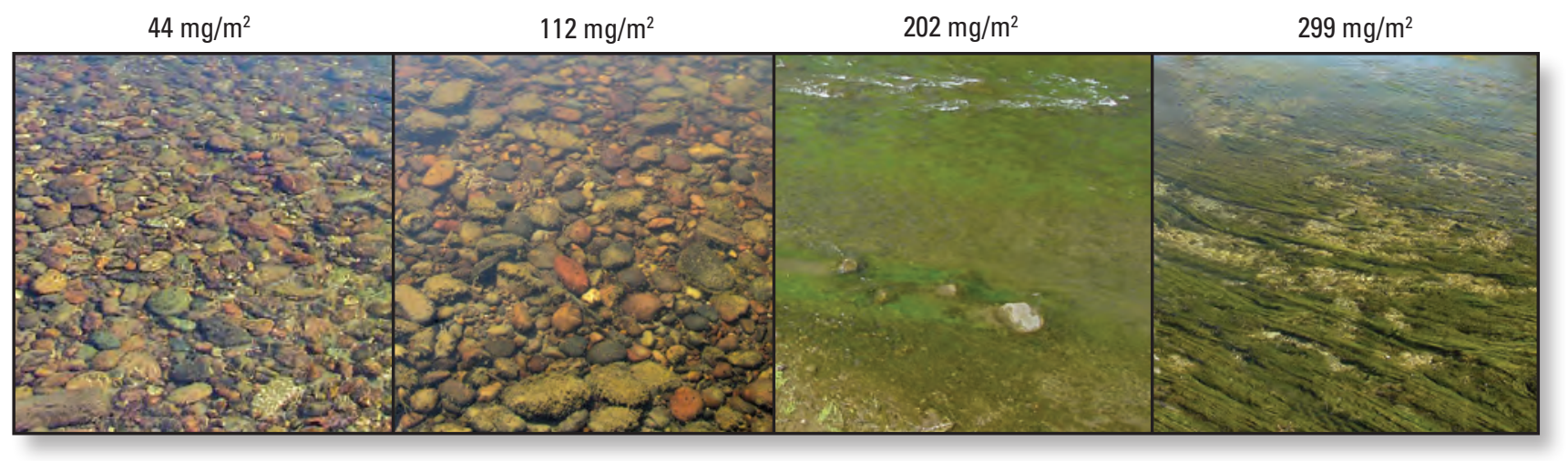

Visual surveys have been conducted to determine what level of algal biomass, including both algae and vascular plants, is considered acceptable to the public (Suplee and others, 2009; reprinted with permission). The survey reported that levels less than 100-150 milligrams of chlorophyll a per square meter were aesthetically acceptable to the public. 

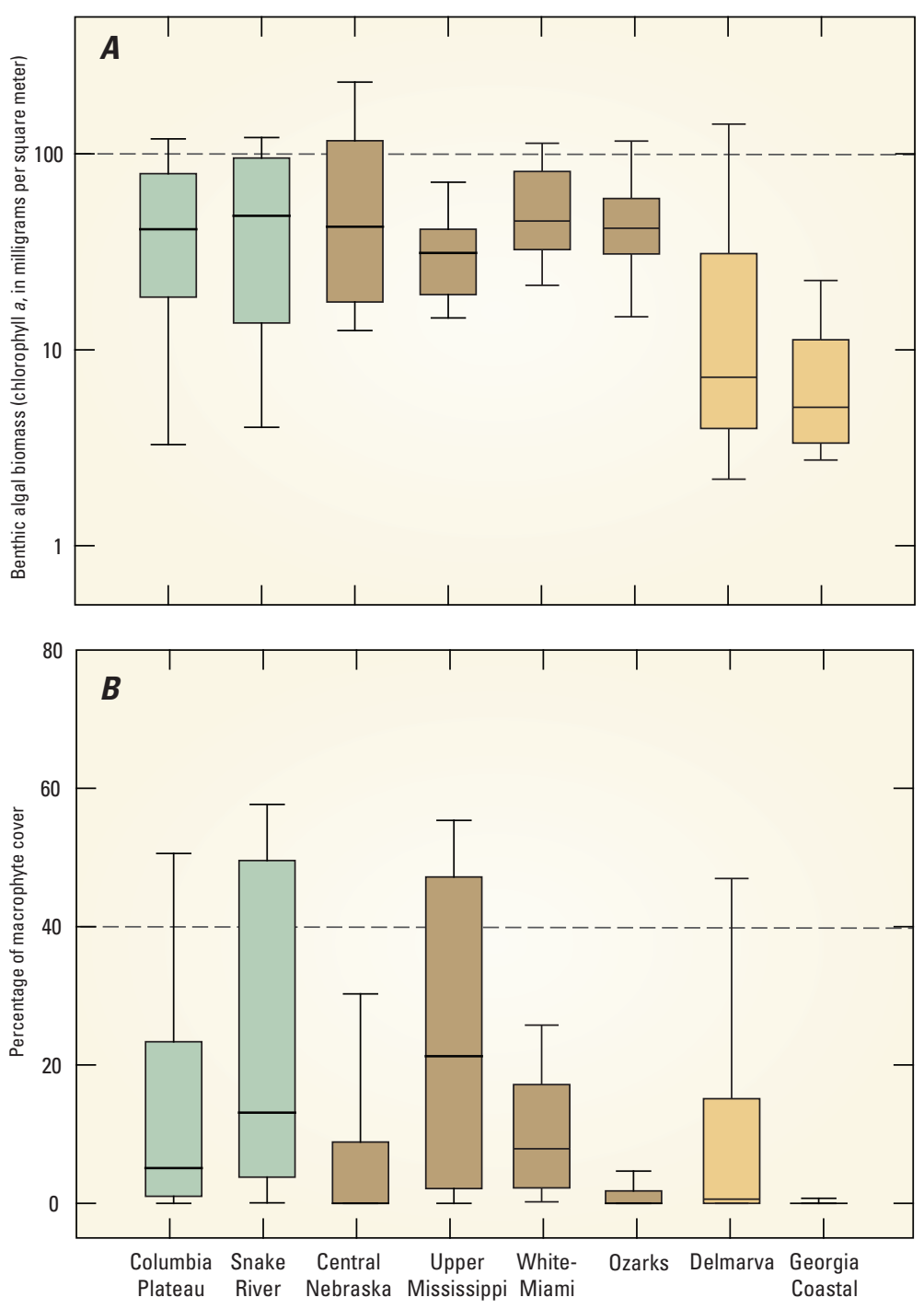

\section{EXPLANATION}

\section{Study area}

Western Region

Central Region

Eastern Region

90th percentile

75th percentile

median

25th percentile

$\perp$ 10th percentile

Figure 5-2. Benthic algal biomass exceeded the 100 milligrams per square meter benchmark for both potential ecological alteration (Welsh and others, 1998) and aesthetically unacceptable to the public (Suplee and others, 2009) (dashed line) at 13 percent of the sites in this study, with biomass lowest in the Eastern Region $(A)$. In contrast, percentage of macrophyte cover $(B)$ showed greater variation with the highest levels in the Snake River and Upper Mississippi; only 10 percent of sites exceeded the 40 percent benchmark level indicating onset of potential eutrophic conditions (dashed line).

levels of aquatic macrophyte cover, and it is likely that the level would vary depending on the region or stream. A eutrophic benchmark of 40 percent cover was used for comparison (Maret and others, 2010) based on studies by Chambers and others (1999) and Suplee and others (2009). Based on this, 10 percent of the 232 sites exceeded the 40 percent benchmark level. Aquatic macrophytes were most abundant in the Snake River and Upper Mississippi, with median values of 13 and 21 percent cover, respectively. This abundance primarily is due to stable streamflow and sufficient light due to low canopy cover (see section, "Role of Habitat in Controlling Aquatic Vegetation"). Dense macrophyte cover often reduces the amount of sunlight reaching the stream bottom, which reduces the growth and ultimately the biomass of benthic algae (fig. 5-3). If only benthic algal biomass is used for assessing status of aquatic vegetation, streams dominated by extensive macrophyte growth would be misclassified as to their potential biological condition. 


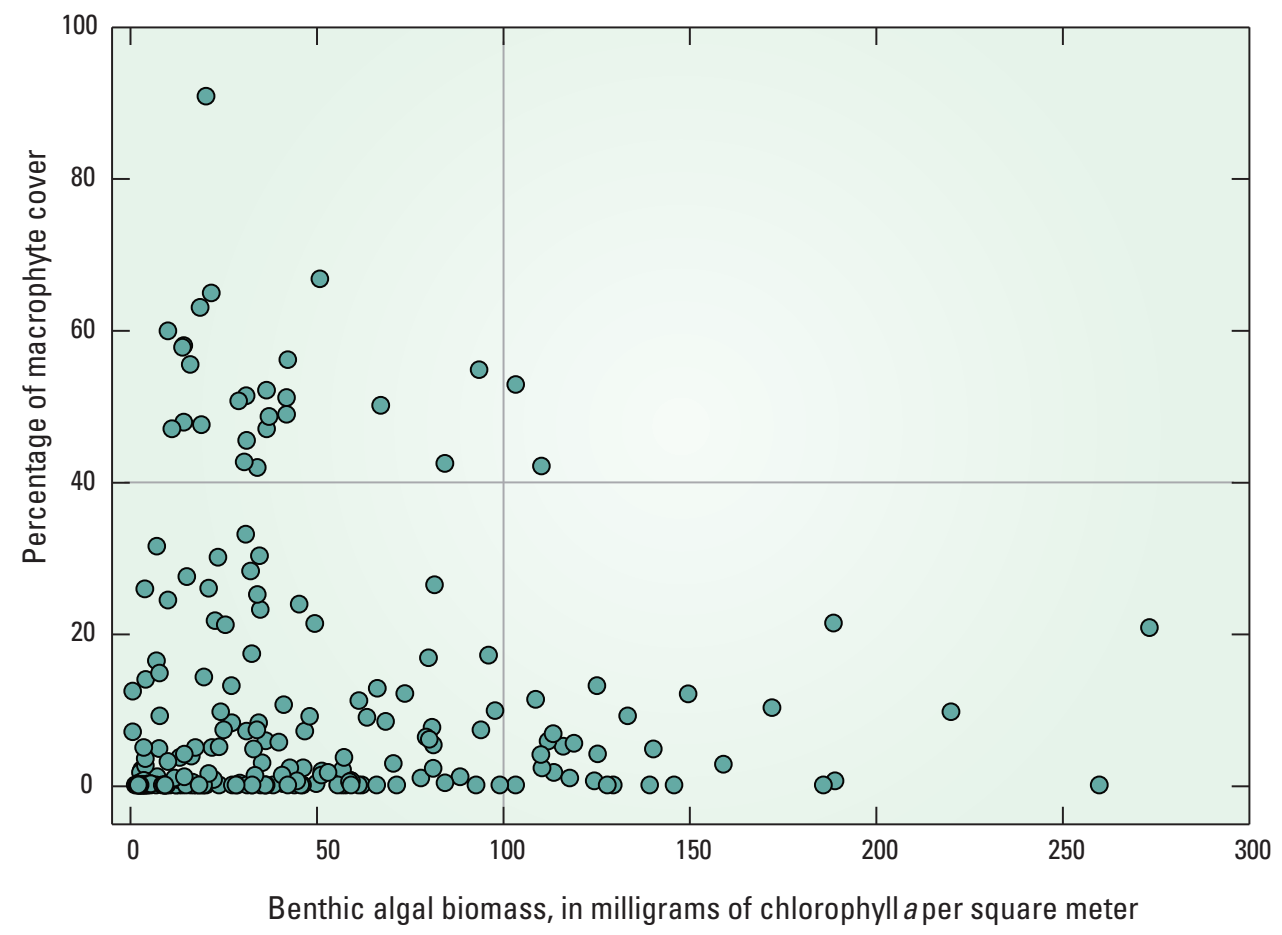

Figure 5-3. Increased macrophyte cover can limit the growth of benthic algae due to shading, consequently, benthic algal biomass rarely exceeds levels of concern (vertical line: greater than 100 milligrams of chlorophyll a per square meter) when percentage of macrophyte cover is high (horizontal line: greater than 40 percent cover).

\section{Influence of Nutrients on Aquatic Vegetation}

Nutrients generally are a poor predictor of algae in streams.

Benthic algae require nutrients for growth; however, nutrient concentrations alone are often a poor predictor of benthic algal biomass. Nationally, orthophosphate was the only nutrient species with a positive correlation with benthic algal biomass; however, the correlation was weak and primarily due to differences among study areas distributed along a nutrient concentration gradient. Within individual areas, nutrient species and algal biomass were significantly correlated for Delmarva and Snake River. In the Delmarva, concentrations of total phosphorus explained 34 percent of the variation in benthic algal biomass (fig. 5-4A), whereas, in the Snake River, total nitrogen explained 14 percent of the variation in benthic algal biomass (not shown). The positive correlation for these two areas occurred because these streams spanned a wide range in total phosphorus and total nitrogen concentrations, with sites less than and greater than the nutrient threshold of about $0.03 \mathrm{mg} / \mathrm{L}$ for total phosphorus and about $0.5 \mathrm{mg} / \mathrm{L}$ for total nitrogen (Dodds and others, 2002;
Stevenson and others, 2006). These two areas are examples of settings where nutrients and algal biomass follow the idealized linear relation (fig. 5-4).

The reasons benthic algal biomass and nutrients do not correlate in other study areas differed among areas. For example, total phosphorus concentrations in the Georgia Coastal spanned the threshold of $0.03 \mathrm{mg} / \mathrm{L}$, but did not result in a response by benthic algae (fig. 5-4B). This area has extensive riparian forested wetlands with heavy canopy cover, which reduces light penetration to streams. Consequently, the Georgia Coastal sites are in the lower left and right of the conceptual model where habitat can limit the growth of algae (Munn and others, 2010). In contrast, data for the White-Miami sites showed no relation between benthic algal biomass and total phosphorus because concentrations were above the threshold level of $0.03 \mathrm{mg} / \mathrm{L}$ and total phosphorus concentrations were sufficient at most all sites for sustaining algal growth (fig. 5-4C). The White-Miami sites are in the upper right quadrant where nutrient concentrations exceed what is required for algae. 

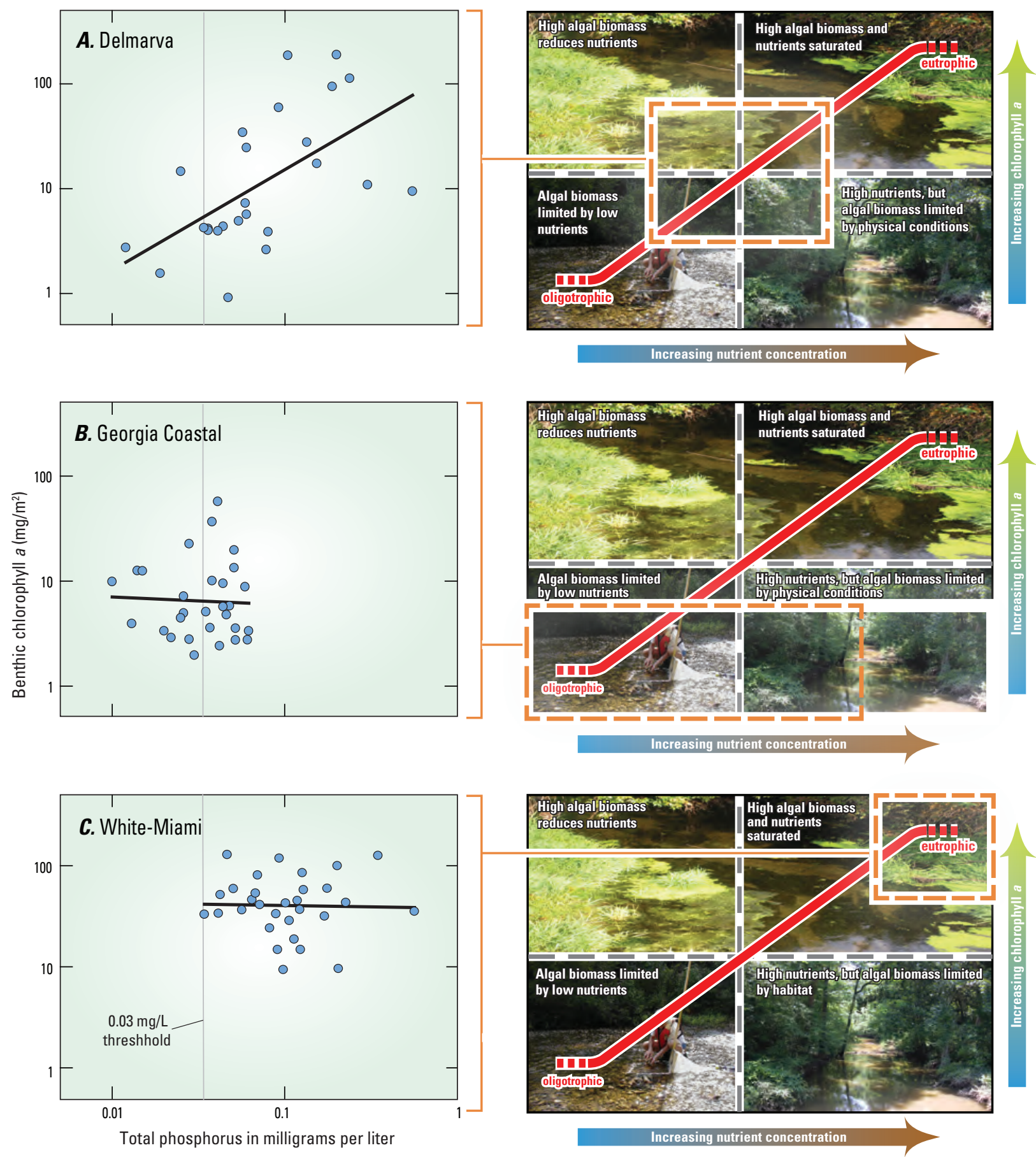

Figure 5-4. The relation between total phosphorus and benthic algal biomass at three study areas illustrates contrasts in the response of algae to different ranges in nutrient concentrations in different habitats. The Delmarva $(A)$ area had a statistically significant relation between benthic algal biomass and total phosphorus $\left(r^{2}=0.34, p<0.05\right)$. In contrast, the Georgia Coastal $(B)$ area had total phosphorus concentrations that spanned the threshold value of $0.03 \mathrm{mg} / \mathrm{L}$ (Dodds and others, 2002; Stevenson and others, 2006); however, the streams commonly had high canopy cover, which reduces light penetration, so algal growth was generally low. Most sites in the White-Miami $(C)$ area contained high concentrations of total phosphorus and moderate to high benthic chlorophyll a; concentrations far exceeded what is required for algae. 


\section{The Role of Habitat in Controlling Aquatic Vegetation}

\section{Streambed Sediments May Be an Important Reservoir of Phosphorus in Streams for Rooted Aquatic Macrophytes}

Most efforts to manage nutrients in streams are focused on nutrient concentrations in the water column; however, streambed sediments can be an important reservoir of phosphorus. Sediment phosphorus levels and aquatic macrophyte biomass (measured as dry weight) were measured in the Snake River study area where some streams have extensive beds of aquatic macrophytes. Total phosphorus measured in water had little or no relation to aquatic macrophyte biomass (fig. 5-5A). In contrast, macrophyte biomass increased with increasing concentrations of loosely sorbed phosphorus concentrations in streambed sediments (fig. 5-5B), which is the bioavailable form (Simon and others, 2009). Previous studies in other areas also determined that aquatic vegetation obtain most of their phosphorus requirements from sediments, resulting in aquatic plant biomass being disconnected from phosphorus in water (Carignan and Kalff, 1980; Chambers and others, 1989). Measuring water-column nutrient concentrations may not address the nutrients that are driving aquatic macrophyte growth.

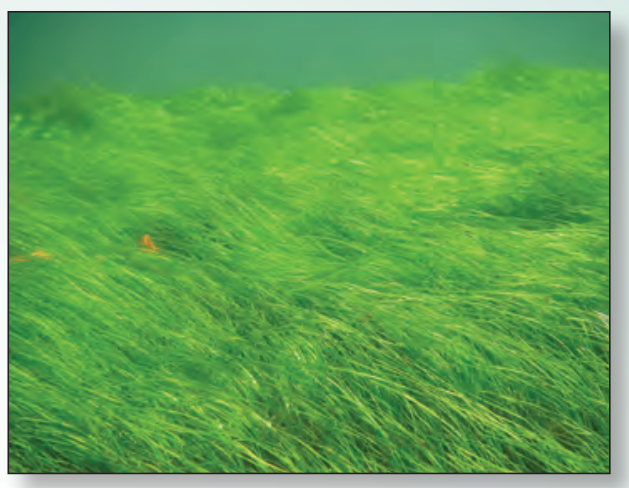

Example of rooted macrophytes in Billingsly Creek, Idaho. Photograph taken by Christopher Mebane, U.S. Geological Survey.

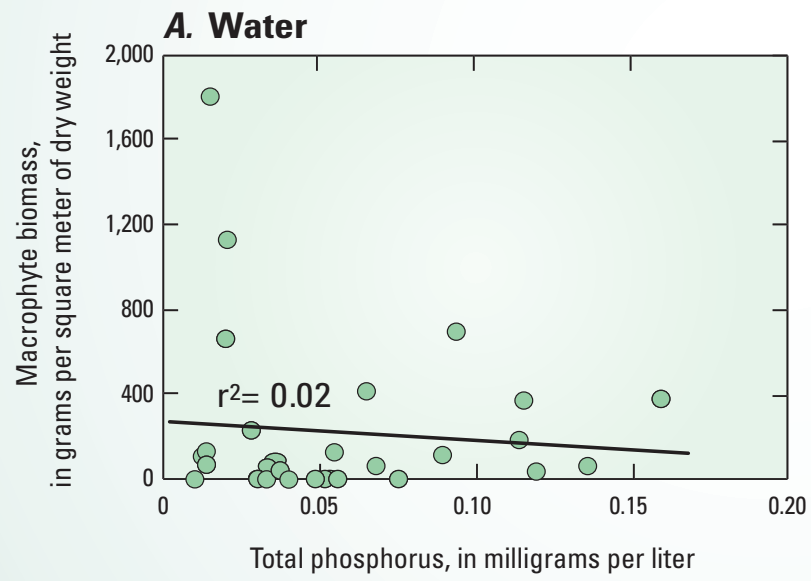

\section{B. Sediment}

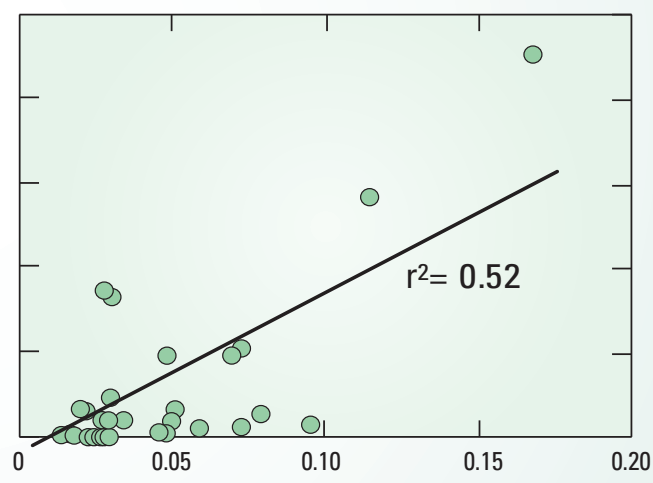

Loosely sorbed phosphorus, in milligrams per gram

Figure 5-5. Phosphorus in stream water during summer was not correlated with macrophyte biomass $(A)$, whereas loosely sorbed phosphorus in sediments (available for uptake by roots) was correlated with biomass $(B)$ at sites in the Snake River (Mebane and others, 2013). 
Habitat limits aquatic vegetation regardless of nutrients.

Stream and riparian habitat conditions are important factors affecting aquatic vegetation in streams. Algal biomass accrual (colonization plus growth) primarily is a function of nutrients, light, and water temperature; whereas biomass losses are a function of streamflow fluctuations and feeding by invertebrates or fish (Biggs, 1996). The amount of biomass measured in a stream is the product of the balance between those processes that promote growth, and those that promote removal. Therefore, nutrients are only one of many factors that control aquatic vegetation. For example, total phosphorus explained only 12 percent of the variability in benthic algal biomass alone among 143 sites in this study (Munn and others, 2010); however, when habitat factors (substrate, flow, velocity, and canopy cover) were included in the analysis, 32 percent of the variance in benthic algal biomass was explained.

Light is considered the primary controlling factor for algae with nutrients second (Hill and Fanta, 2008). Stream canopy cover is one habitat feature that regulates light and therefore indirectly influences aquatic vegetation growth. Benthic algal biomass and percentage of macrophyte cover were assessed under low, moderate, and high canopy cover (fig. 5-6). Benthic algal biomass was similar between low and moderate canopy cover, but decreased about 25 percent when canopy cover exceeded greater than 66 percent (fig. 5-6A). In contrast, there was a decrease in macrophyte cover as canopy cover increased from low to moderate, with macrophytes rare in streams where canopy cover was greater than 66 percent (fig. 5-6B). Therefore, canopy has a stronger influence on macrophyte cover than on benthic algal biomass. These findings show that it is important to classify streams into open or closed canopy systems to better understand the relations between nutrients and aquatic vegetation.

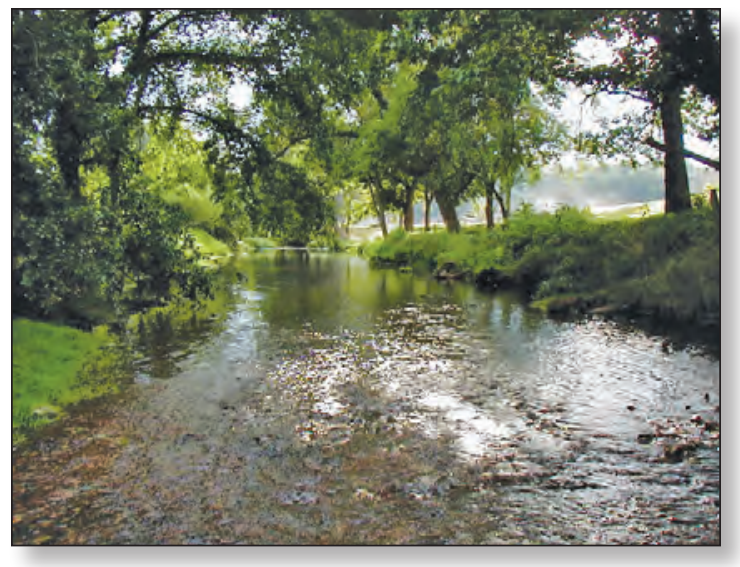

Canopy prevents high plant growth, North Indian Creek, Arkansas. Photograph taken by James Petersen, U.S. Geological Survey.

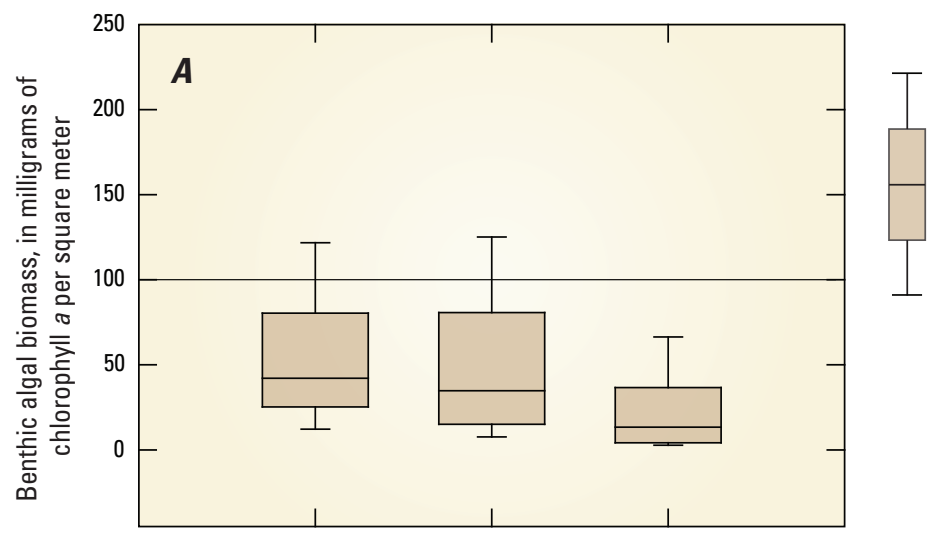

EXPLANATION

90th percentile

75th percentile median

25th percentile

10th percentile

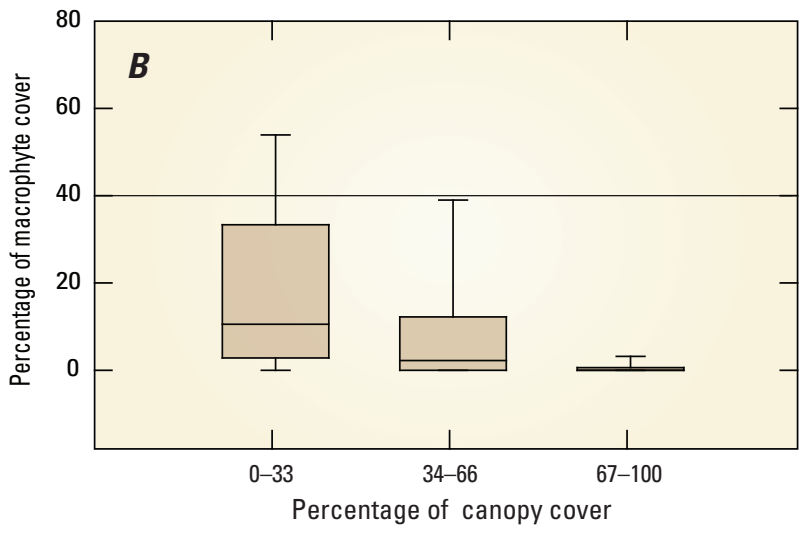

Figure 5-6. Canopy cover can limit the amount of light available for macrophytes and benthic algae in agricultural streams. Benthic algal biomass decreases when canopy cover is greater than 66 percent $(A)$, whereas percentage of macrophyte cover decreases substantially at 34 percent, and is rare at 67 percent cover $(B)$. Horizontal lines indicate benchmark levels; values above are considered excessive. 


\section{Using Dissolved Oxygen as an Indicator of Primary Production and Stress to Aquatic Life}

Primary production-Aquatic primary producers are algae and aquatic plants that obtain their energy from a combination of sunlight and nutrients (termed photosynthesis), and produce biomass. An important byproduct of this process is dissolved oxygen, which is required by all animal life. Because photosynthesis requires light, dissolved oxygen is only produced during the daytime, whereas respiration occurs over a 24-hour period. Measuring changes in dissolved oxygen over 24 hours is an important measure of the overall primary production of a stream, along with providing information on the range of dissolved oxygen, which can be a sign of stress to aquatic life.

Dissolved-oxygen concentrations were below levels of protection for native fish at approximately 15 percent of sites.

Dissolved oxygen is an indicator of both aquatic vegetation growth and potential stress to aquatic life. Primary production is a key ecosystem process that reflects the overall health and trophic status of a stream. Primary production responds directly to changes in light, which is influenced by riparian buffers and suspended sediment, along with changes in nutrients. Natural levels of primary production are important for maintaining the food base; however, excess production can result in habitat alteration and severe depletion of dissolved oxygen due to respiration. Many states set minimum dissolved-oxygen levels to protect various classes of streams.

To characterize primary production and respiration, dissolved-oxygen concentrations were measured continuously at 46 of the 232 sites (20 percent) over a 3-day period during the summer growing season. The night-time minimum dissolved-oxygen concentration was less than the $5-\mathrm{mg} / \mathrm{L}$ level at approximately 15 percent of the 46 sites; sites with low dissolved-oxygen concentrations generally had extensive agriculture (median of 62 percent), low canopy cover (median of 8 percent), and moderate total nitrogen and total phosphorus concentrations (median of 2.0 and $0.1 \mathrm{mg} / \mathrm{L}$, respectively).

Measurements from three contrasting areas illustrate the range of dissolved-oxygen concentrations determined in this study. Morgan Creek (Delmarva) represents a system with low benthic algal biomass ( $9 \mathrm{mg}$ chlorophyll $a / \mathrm{m}^{2}$ ) and no macrophyte cover. This stream had extensive canopy cover (75 percent) and therefore light penetration was low. This low light penetration restricts the amount of dissolved oxygen that can be produced through photosynthesis; therefore, this system has relatively low variation in 24-hour dissolved-oxygen concentrations (fig. 5-7). In contrast, Maple Creek (Central Nebraska) represents a system lacking any canopy cover, with high benthic algal biomass (66 $\mathrm{mg}$ chlorophyll $\mathrm{a} / \mathrm{m}^{2}$ ) and no macrophyte cover, resulting in greater oxygen production during the daylight period. Although this results in a wider swing in dissolved oxygen over a 24-hour period, concentrations do not fall below levels considered protective of fish (5 mg/L, fig. 5-7). Stalker Creek (Idaho) also represents an open canopy system with high light penetration; however, this site has extensive benthic algal biomass ( $80 \mathrm{mg}$ chlorophyll $\mathrm{a} / \mathrm{m}^{2}$ ) and macrophyte cover (49 percent), resulting in high dissolved oxygen production during daylight and dissolved oxygen below levels considered protective of fish during the nighttime.

\section{Primary production in agricultural streams varied greatly among the different study areas}

Along with understanding minimum dissolved oxygen in streams, monitoring continuous dissolved oxygen permits the calculation of primary production, which is the amount of dissolved oxygen produced per unit area per time (grams of dissolved oxygen per square meter per day $\left[\left(\mathrm{g} \mathrm{O}_{2} / \mathrm{m}^{2}\right) / \mathrm{d}\right]$. Site primary production ranged from 0 to $11.7\left(\mathrm{~g} \mathrm{O}_{2} / \mathrm{m}^{2}\right) / \mathrm{d}$. Individual study area medians ranged from a national reference site median (Bernot and others, 2010) to substantially greater

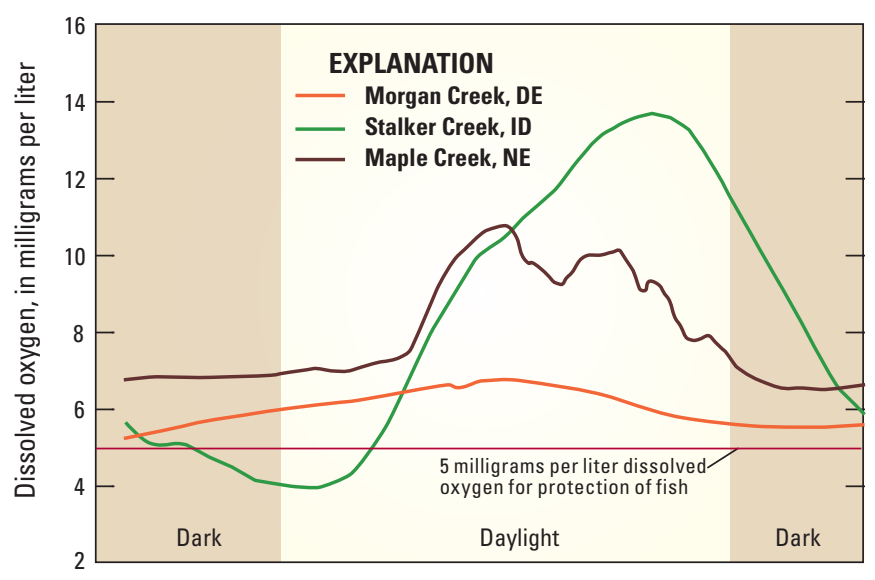

Figure 5-7. Daily swings in dissolved oxygen tend to be greatest in macrophyte dominated streams (Stalker Creek, Idaho), moderate at algal dominated streams (Maple Creek, Nebraska), and lowest in light limited streams (Morgan Creek, Delaware). 
than the national median for agricultural lands (Bernot and others, 2010) (fig. 5-8). The higher production in the Snake River and Upper Mississippi streams reflect the extensive growth of aquatic macrophytes (medians of 13 and 22 percent cover, respectively) in many site streams. Statistical analysis indicated that 24 percent of the variation in primary production was explained by percent macrophyte cover and stream width/depth.

\section{Influence of Benthic Invertebrates on Benthic Algal Biomass}

Benthic invertebrates can reduce algal biomass.

Biological assessments focus on how physical or chemical factors influence biological communities; however, interactions with other biota play a strong role in the amount of aquatic vegetation that can occur in many streams. This is particularly true with invertebrates that feed on algae attached to the stream bottom, referred to as grazers. Seasonal data collected from a subset of streams in the Ozarks show that grazing invertebrates were most extensive during the summer and autumn (Maret and others, 2010). A pattern of increasing snail densities and decreasing summer benthic algal biomass was observed in five of the seven Ozark streams that were sampled seasonally. To illustrate this finding, algae biomass and snail densities were compared across seasons for Shoal Creek, an Ozark stream in Missouri (fig. 5-9). Algal biomass was high in the spring and then decreased as the snail density increased about 10-fold to more than 1,000 individuals per square meter. When algal biomass is initially dense, grazing by invertebrates may reduce algal biomass by a factor of as much as 10 (Feminella and Hawkins, 1995). In contrast, when benthic algal biomass is sparse, invertebrate grazing can stimulate growth. Invertebrates also can influence each other. For example, in Western Region agricultural streams with high nutrients, invasive snails have displaced intolerant insects commonly used in bioassessments (Ephemeroptera, Plecoptera, and Trichoptera) (Maret and others, 2008). These intolerant taxa are indicators of good water quality and habitat.

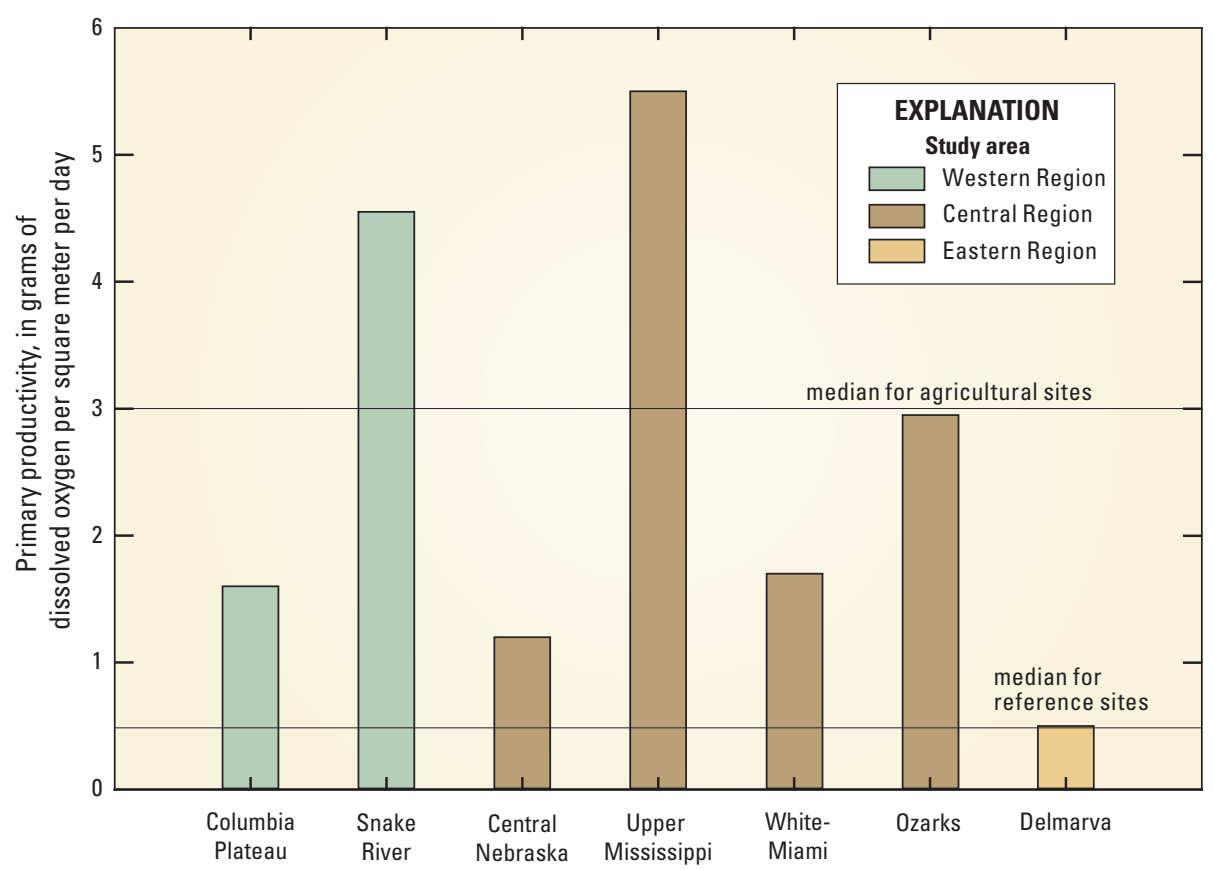

Figure 5-8. Median primary production in the study areas ranged from values similar to those at reference sites to values substantially greater than usually seen at agricultural sites (median reference and agricultural values from Bernot and others, 2010). 

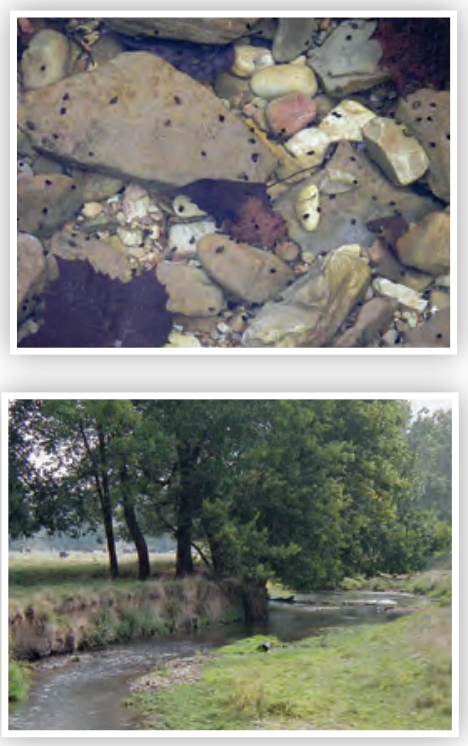

Shoal Creek, Missouri

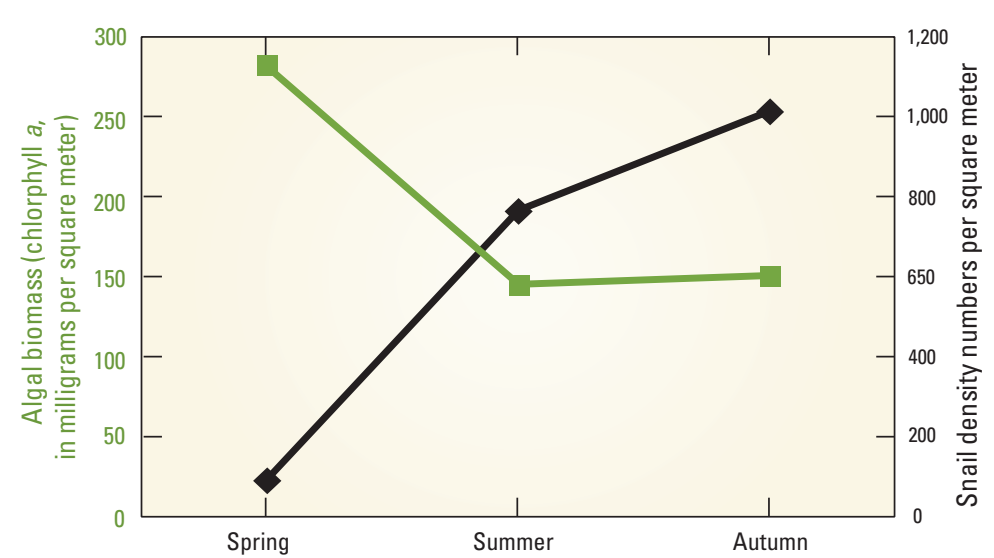

Figure 5-9. Seasonal patterns suggest snail grazing may play an important role in controlling algae biomass in some Ozark streams. Algal biomass decreases in Shoal Creek, Missouri, as density of grazing snails increases by a factor of about 10. Left photograph shows high density of grazing snails on stream rocks. Photographs taken by James Petersen, U.S. Geological Survey.

\section{Influence of Seasonal Streamflow on Benthic Algal Biomass}

Seasonal streamflow patterns have a major influence on aquatic vegetation.

Spring snowmelt and precipitation control hydrologic events in the Snake River resulting in the delivery of large quantities of surface runoff during that period relative to late summer. The Bigwood River (Idaho) watershed, which drains shrublands and grasslands, illustrates a stream dominated by snowmelt-runoff in the spring and early summer and by groundwater discharge later in the season. The combination of nutrients and sunlight in early spring result in rapid growth of benthic algae, as expressed by chlorophyll $a$ (fig. 5-10). Benthic algal biomass begins to increase prior to snowmelt, but rapidly decreases from May to June due to scouring by high streamflow. Following the high-flow period, nutrient inputs from surface runoff decrease and stream concentrations take on the characteristics of incoming groundwater. Benthic algal biomass stabilizes during this more stable flow and nutrient concentration period (Lee and others, 2012).

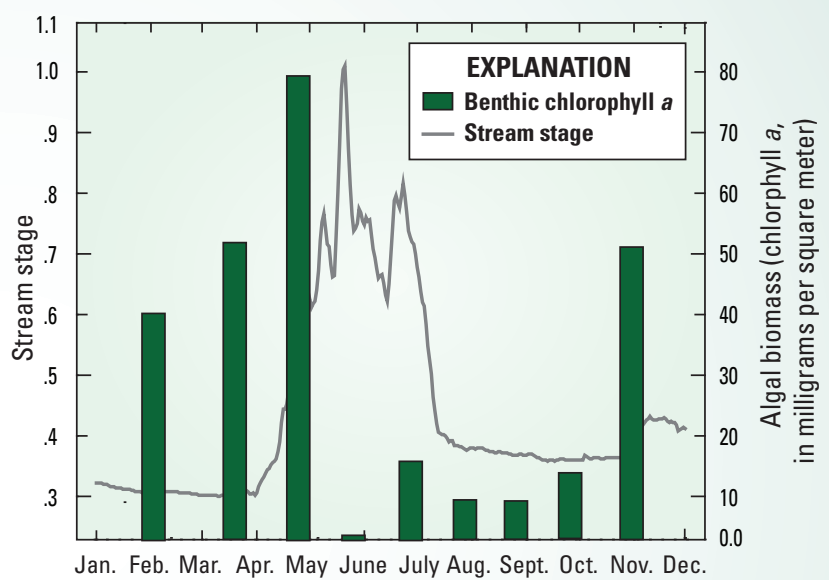

Figure 5-10. Benthic algal biomass is influenced by changes in seasonal streamflow patterns. 


\section{Chapter 6. Influence of Nutrients and Habitat on Biological Communities}

\section{Introduction}

The complex interactions of nutrients, habitat, and biological communities suggest that relying on nutrient concentrations alone could lead to the misclassification of stream health. Biological communities are relatively sensitive to changes in the physical and chemical conditions in the stream environment, and therefore were used in this study to assess the health of agricultural streams. Biological condition is a measure of the degree to which biological communities differ from a natural state; generally, biological metrics are compared with those at relatively natural sites to assess status of, or change in, condition of the biological community (see "Measuring Biological Condition"). In this chapter, the response of algal and invertebrate communities to nutrient concentrations are assessed along with other important environmental factors affecting biological condition throughout agricultural regions of the country.

\section{Geographic Distribution of Biological Condition}

Biological condition was lowest in the upper Midwest agricultural streams.

Biological condition values based on algal or invertebrate metrics were the lowest in the northern Central Region, where the percentage of land in agricultural use is highest (fig. 6-1). In general, biological conditions were low in areas where nutrient inputs and stream nutrient concentrations were among the highest - the Central Nebraska, Upper Mississippi, and White-Miami areas along with the eastern Delmarva. In contrast, the remaining four study areas (Columbia Plateau, Snake River, Ozarks, Georgia Coastal) all contained sites with a wider range of biological condition, with many sites reflecting minimally disturbed or reference conditions.
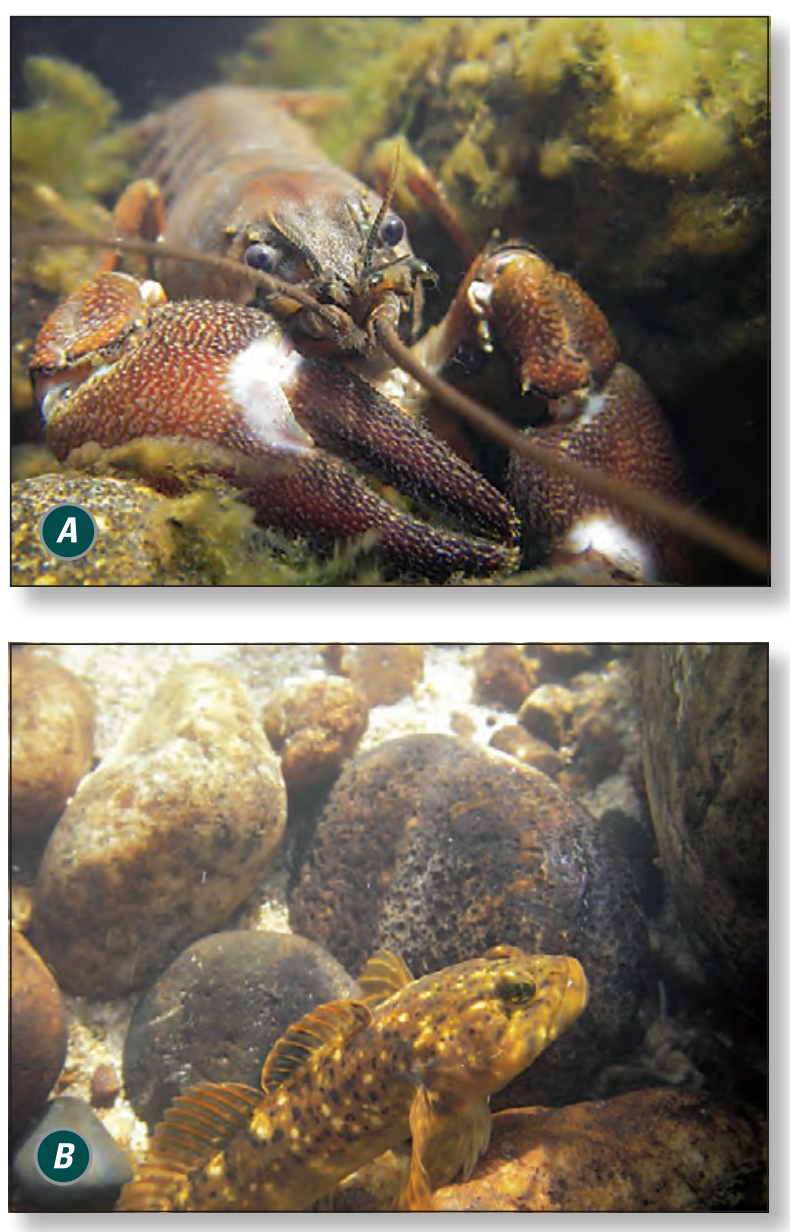

Crayfish $(A)$ and sculpin $(B)$ in Boise River, Idaho. Photographs taken by Christopher Mebane, U.S. Geological Survey. 


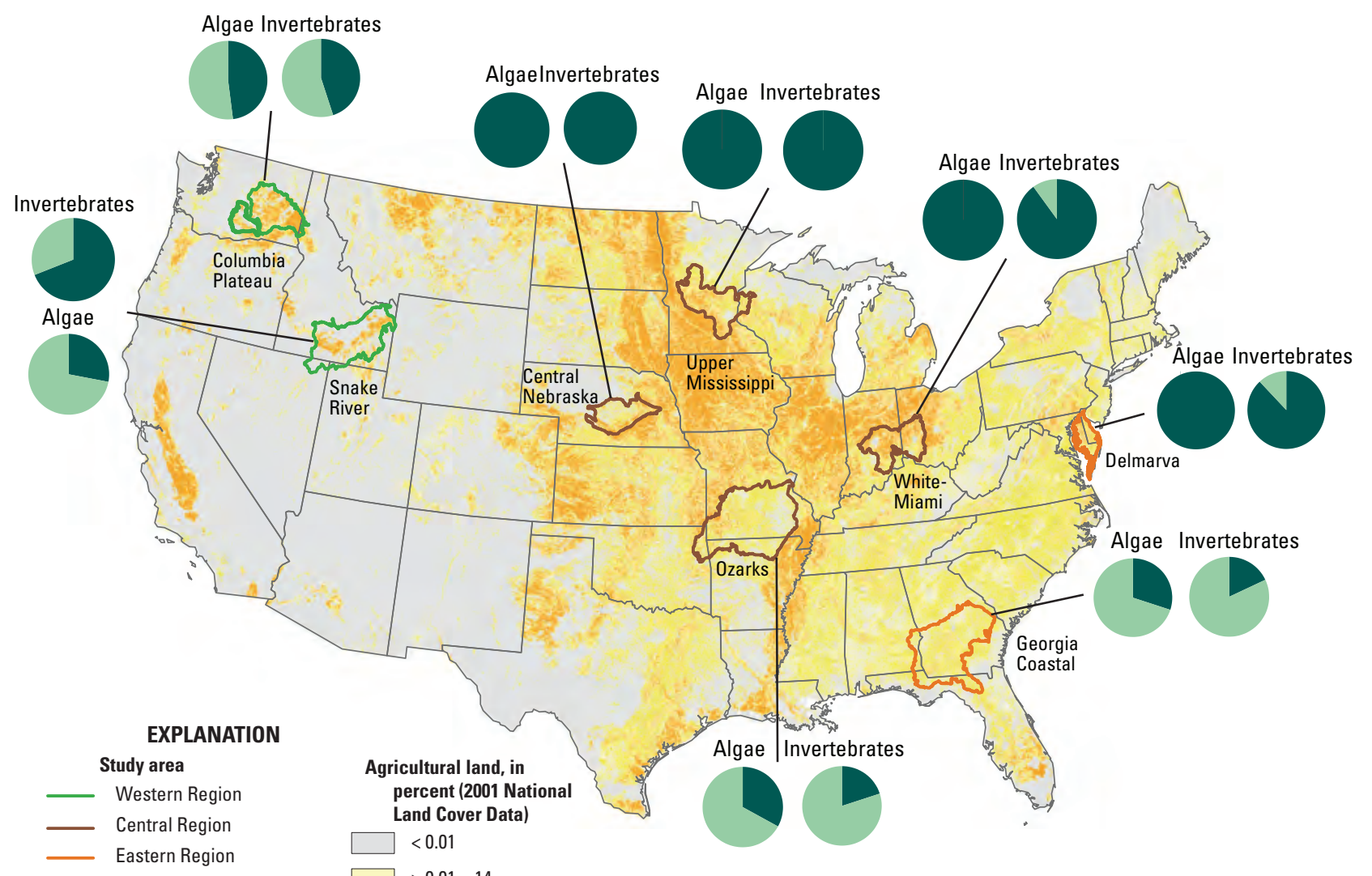

Biological condition

Altered sites $(<80$ percent)

$>14-\leq 48$

$>48-\leq 84$

Figure 6-1. Most altered streams, based on algae or invertebrate condition, were in those study areas with the greatest agricultural land use.

\section{Influence of Nutrients on Biological Condition}

\section{Biological condition decreases with increased nutrient concentrations.}

Biological condition of streams was compared among three nutrient categories, which were based on the lower, middle, and upper third of the summer concentrations for samples from all surface-water sites monitored by NAWQA from 1992 to 2001 (fig. 6-2; Mueller and Spahr, 2006). Sites with reference-like biological condition-indicated by scores greater than or equal to 80 percent- - had total nitrogen and total phosphorus concentrations in the lowest nutrient category. Biological condition scores of algae and invertebrates decreased by 40 and 30 percent, respectively, as nutrient concentrations increased. Mean biological condition scores for algae and invertebrates for streams in the upper total nitrogen category were 46 and 54 percent, respectively (fig. 6-2). Mean biological condition for algae and invertebrates for streams in the upper total phosphorus category were slightly lower (38 and 42 percent, respectively). Although biological communities in agricultural watersheds are often exposed to a complex variety of physical habitat and water-quality issues, nutrients are well established as major stressors affecting biological communities (U.S. Environmental Protection Agency, 2006).

\section{Natural and anthropogenic factors influence regional} biological responses to nutrients.

Biological communities respond naturally to factors in a region (for example, geology and climate). These natural factors combined with human-related factors (such as agricultural or urban development), influence which taxa are able to reside in a stream in a given region. For example, in the two Western Region study areas (Snake River and Columbia Plateau) there is a continuous decrease in EPT richness with increasing total nitrogen concentrations (fig. 6-3). 

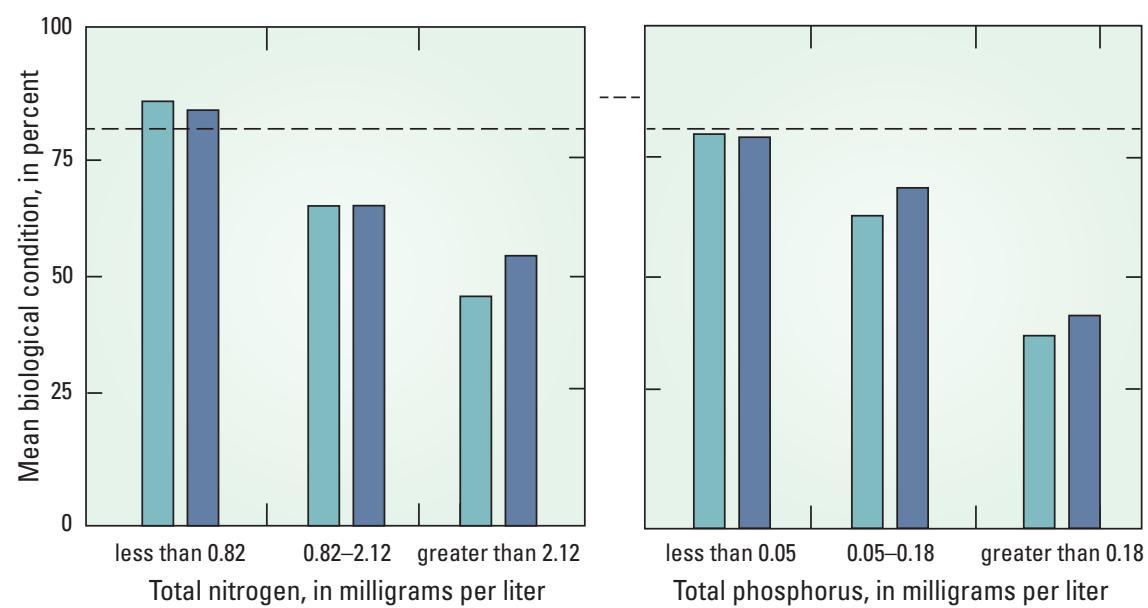

EXPLANATION

Algae

$\square$ Invertebrates
Figure 6-2. Mean biological condition (based on observed/expected scores) of algae and invertebrate communities decreased with increasing concentrations of total nitrogen and total phosphorus in agricultural streams across the United States. The three nutrient categories are based on the lower, middle, and upper one-third of the summer concentrations for samples from all surface-water sites monitored by NAWQA from 1992 to 2001 (Mueller and Spahr, 2006). Bars above dashed line infer biological communities similar to reference conditions, whereas bars below dashed line infer that sites differ from reference conditions.

\section{Measuring Biological Condition}

Biological condition is a measure of the overall health of a stream ecosystem and is based on various community indicators or metrics. Agricultural activities generate various stressors that can negatively influence biological communities. Potential stressors include increased nutrients, sediment, pesticides, non-native species, and altered flow conditions.

One effective measure of biological condition compares the observed number of taxa at a sampling site to the number of taxa expected based on a set of regional reference sites, commonly referred to as the $\mathbf{O} / \mathbf{E}$ score. The biological condition metric is a percentage value based on the number of taxa observed (O) at a given site divided by the expected (E) number of taxa at that site given no disturbance (Van Sickle and others, 2005; Carlisle and Meador, 2007). It is important that reference sites appropriate for different regions are selected because the quality of reference sites available in a region is the basis for determining biological condition. In this report, minimally disturbed conditions used to determine expected biological condition were estimated within each of the three regions from wadable streams with low Agricultural Intensity Index scores (see Chapter 3 for an explanation of the Agricultural Intensity Index). Stream O/E values exceeding 80 percent indicate unaltered biological condition whereas stream $\mathrm{O} / \mathrm{E}$ scores of less than 80 percent represent altered biological condition (Carlisle and Meador, 2007). This percentage represents a 20 percent loss of expected taxa for a region, and may reflect the elimination of important components of the food web resulting in diminished stream ecosystem conditions. Others have used this or similar thresholds for classifying biological condition (Van Sickle and others, 2005; Carlisle and others, 2009).

Biological condition also is assessed using the occurrence or relative abundance of particular benthic algae and invertebrate taxa. One of the most commonly used invertebrate metrics in biomonitoring programs is EPT richness, which is the sum of intolerant aquatic insect taxa in the orders Ephemeroptera (mayflies), Plecoptera (stoneflies), and Trichoptera (caddisflies). The loss of EPT taxa often is associated with a shift in community composition to more tolerant organisms, many of which typically are non-insect invertebrates (Lenat, 1988). This metric is particularly effective in evaluating nutrient concentrations in wadable streams (Miltner and Rankin, 1998). In relation to algae, the relative abundance of eutrophic taxa (species that prefer elevated nutrients) is a stressorspecific algal metric commonly used to evaluate nutrient concentrations in streams (Van Dam and others, 1994; Porter and others, 2008). The presence of eutrophic algae increases incrementally with increasing agricultural land cover in the watershed (Porter and others, 2008). 
The strong negative correlation in the Western Region is well defined because streams there span a range of total nitrogen concentrations from low $(0.1 \mathrm{mg} / \mathrm{L}$, reflecting background conditions) to highly enriched $(6.0 \mathrm{mg} / \mathrm{L})$, but otherwise share many environmental characteristics.

In contrast, in the White-Miami and Central Nebraska, two agricultural areas in the Central Region, there is no relation between total nitrogen concentration and EPT richness (fig. 6-3). The lack of a relation in these systems is partially attributed to uniformly high nutrient concentrations (total nitrogen greater than $1.0 \mathrm{mg} / \mathrm{L}$ ) that are well above modeled reference concentrations of $0.5-0.6 \mathrm{mg} / \mathrm{L}$ (see fig. 4-1).

When all streams in a region contain high concentrations of a nutrient, then nutrients are not a limiting factor. EPT richness generally is higher at the White-Miami sites than at the Central Nebraska sites, which is attributed to natural differences in stream habitat (Munn and others, 2009). Specifically, most of the White-Miami sites had good instream habitat (riffle-runpool) compared to Central Nebraska sites dominated by silt and sand substrate.

Management strategies to improve stream health by reducing nutrient concentrations need to consider natural factors, as well as the magnitude of nutrient enrichment. In the Western Region (Snake River and Columbia Plateau study areas), the wide range of nutrient concentrations and generally good habitat indicate that a modest decrease in nutrient concentrations would likely improve biological condition at many sites. In contrast, in the Central Nebraska and White-Miami areas, nutrient concentrations so greatly exceed biological requirements that a large reduction in nutrients may be needed prior to observing any improvement in biological condition. In addition, if nutrient concentrations were decreased in both the White-Miami and Central Nebraska, it is likely that the White-Miami would show a stronger improvement as a result of having higher quality habitat. The implication is that realistic expectations need to be set for management strategies seeking to improve stream health.

\section{Response patterns of EPT richness to nutrient enrichment}

\begin{abstract}
Regions with a sufficient nutrient gradient can provide States the opportunity to derive nutrient criteria by measuring biological responses.
\end{abstract}
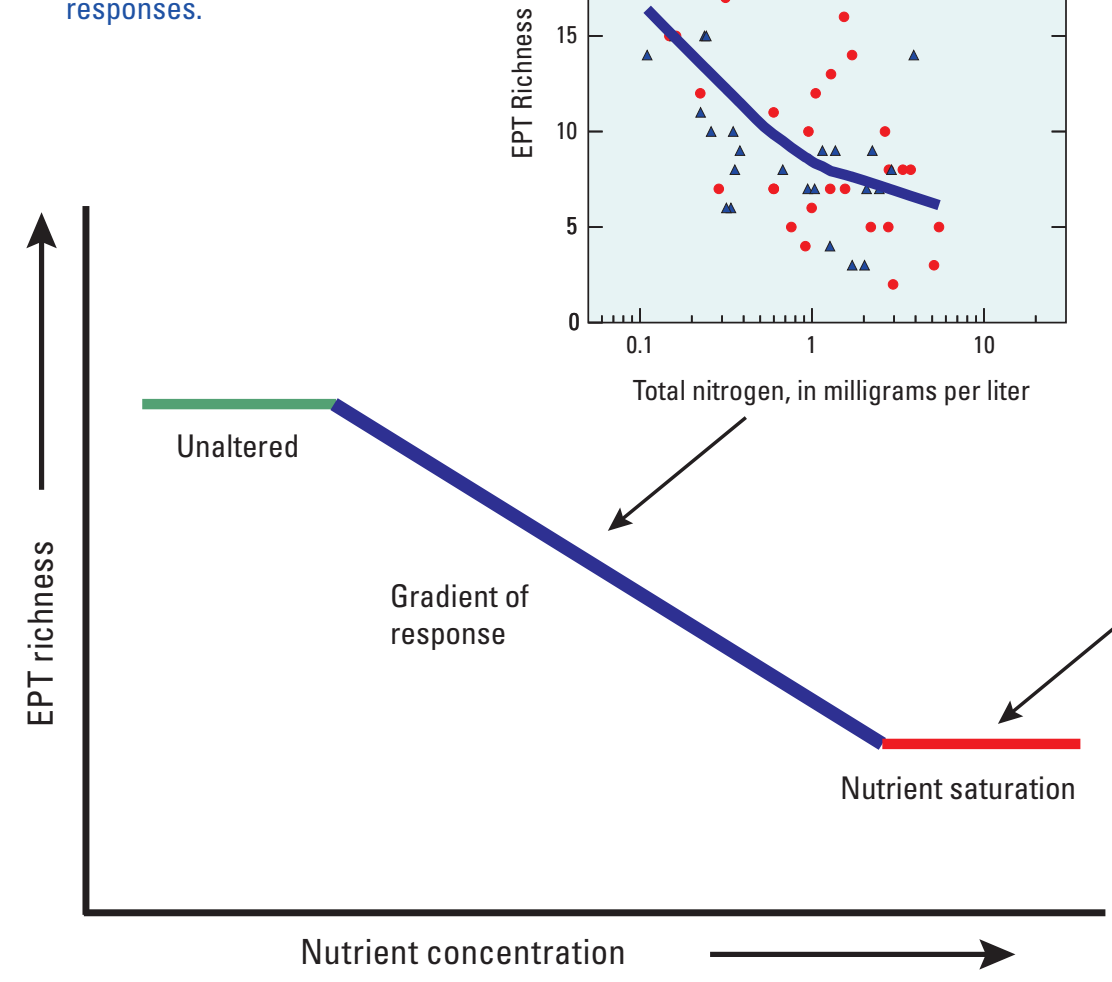
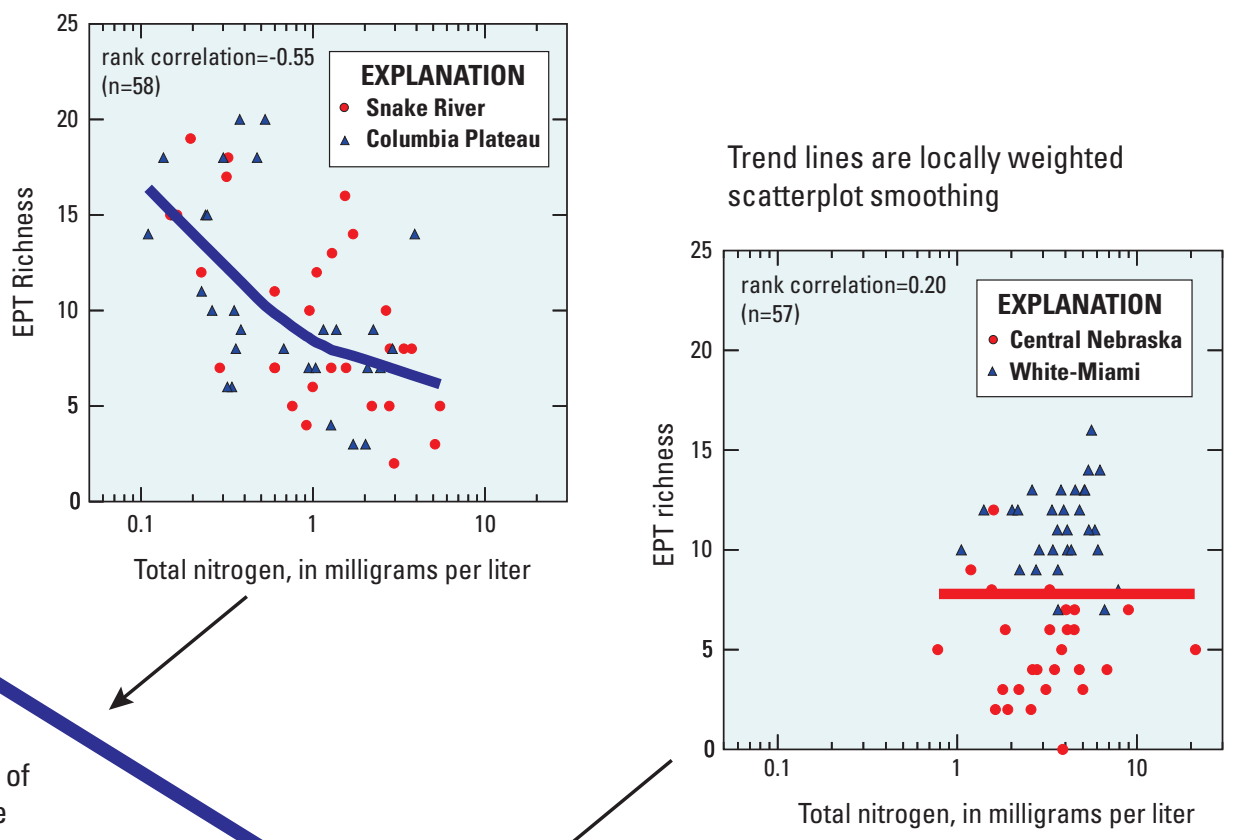

The higher overall EPT richness for the White-Miami sites suggest other environmental factors besides nutrients are important.

Figure 6-3. Biological responses to nutrients vary across agricultural landscapes and partly depend on whether the sites cover a sufficient range of nutrients. The conceptual diagram shows Ephemeroptera, Plecoptera, and Trichoptera (EPT) richness at unaltered sites and the expected decrease in EPT richness with increasing nutrient concentrations. 


\section{Influence of Agricultural Intensity on Biological Condition}

The Agricultural Intensity Index (AII) is a geospatially based index that is strongly correlated with stream nutrient concentrations and can be used in unsampled watersheds to classify streams into nutrient categories. Additionally, nutrient concentrations in surface waters vary seasonally and annually, and the AII provides a more robust assessment of the effect of agricultural activities than measured nutrient concentrations alone (Waite, 2013). The AII incorporates percentage of agriculture in a basin, percentage of cropland in the riparian zone, and simulated input of total nitrogen and total phosphorus to the watersheds (see Chapter 3 for details).

Biological condition in streams decreases as agricultural intensity increases in a watershed.

Generally, biological condition was highest in the Western Region where the Agricultural Intensity score was the lowest; conversely, biological condition was lowest in the Central Region where the Agricultural Intensity score was the highest (fig. 6-4). However, some differences in response occurred depending on whether the metric was based on algae or invertebrates (fig. 6-5). The usefulness of each taxa varies regionally, and selecting a single metric to characterize nutrient enrichment is complicated by a limited understanding of how biological response varies as a function of other physical and chemical stressors. In the Eastern and Central Regions, algae have a more pronounced percent change than the invertebrate metric as agricultural intensity increases from low to moderate (fig. 6-5). The apparent higher sensitivity of the algae metric to agricultural intensity is because benthic algae communities respond directly to nutrient concentrations. In contrast, invertebrate communities respond indirectly to nutrient enrichment in response to changes in food quantity or quality, decreased habitat availability, or diminished dissolved-oxygen concentrations (see section, "Low Dissolved Oxygen Concentrations Lead to Poor Biological Condition”).

Results differed in the Western Region, where the algal metric showed little response compared to the invertebrate metric. These results show how the assessment of more than one stream biological community provides a more comprehensive assessment of biological condition in agricultural watersheds.
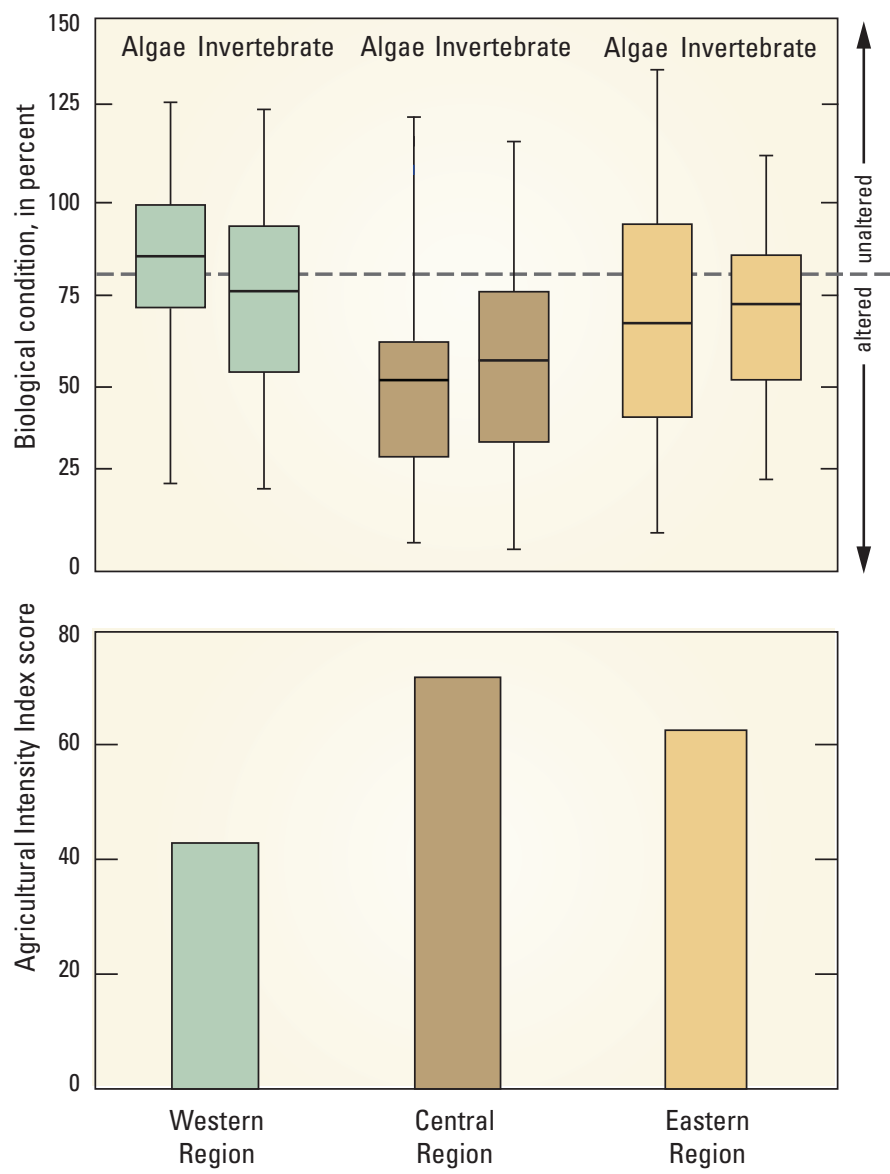

\section{EXPLANATION}

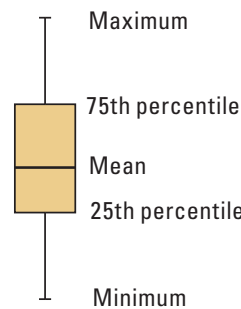

Study Areas

Western Region

Central Region

Eastern Region

Figure 6-4. Biological condition for algae and invertebrate communities was highest in the region with the lowest agricultural intensity. 

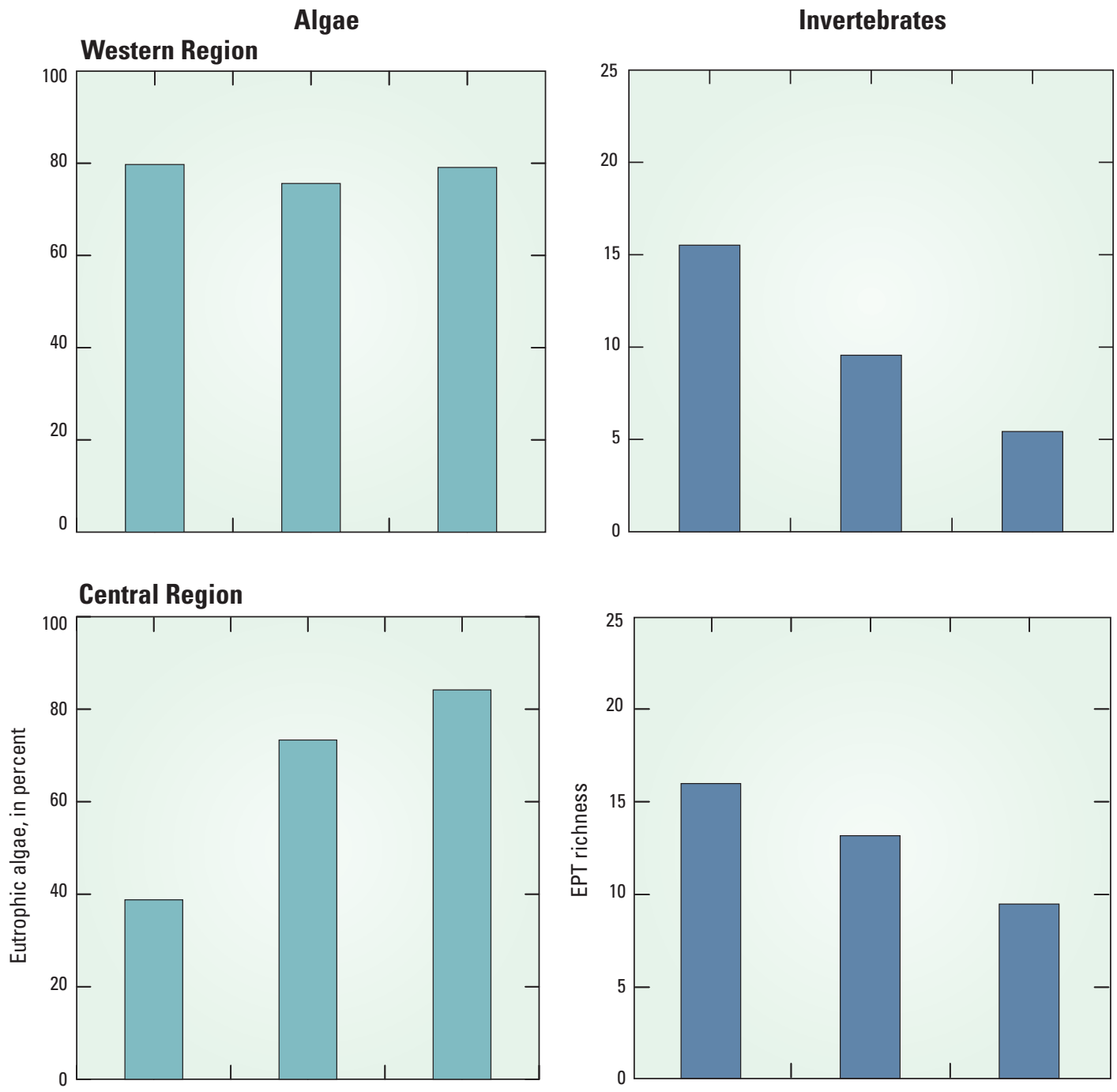

Figure 6-5. Increased agricultural intensity is associated with decreasing biological condition in the Central and Eastern Regions, as indicated by increases in percentage of eutrophic algae and decreases in Ephemeroptera, Plecoptera, and Trichoptera (EPT) taxa richness. These ecological indicators help to evaluate the condition of aquatic communities across a variety of agricultural landscapes with varying degrees of agriculture percentage, agriculture in the riparian buffer, and nutrient input to watersheds.
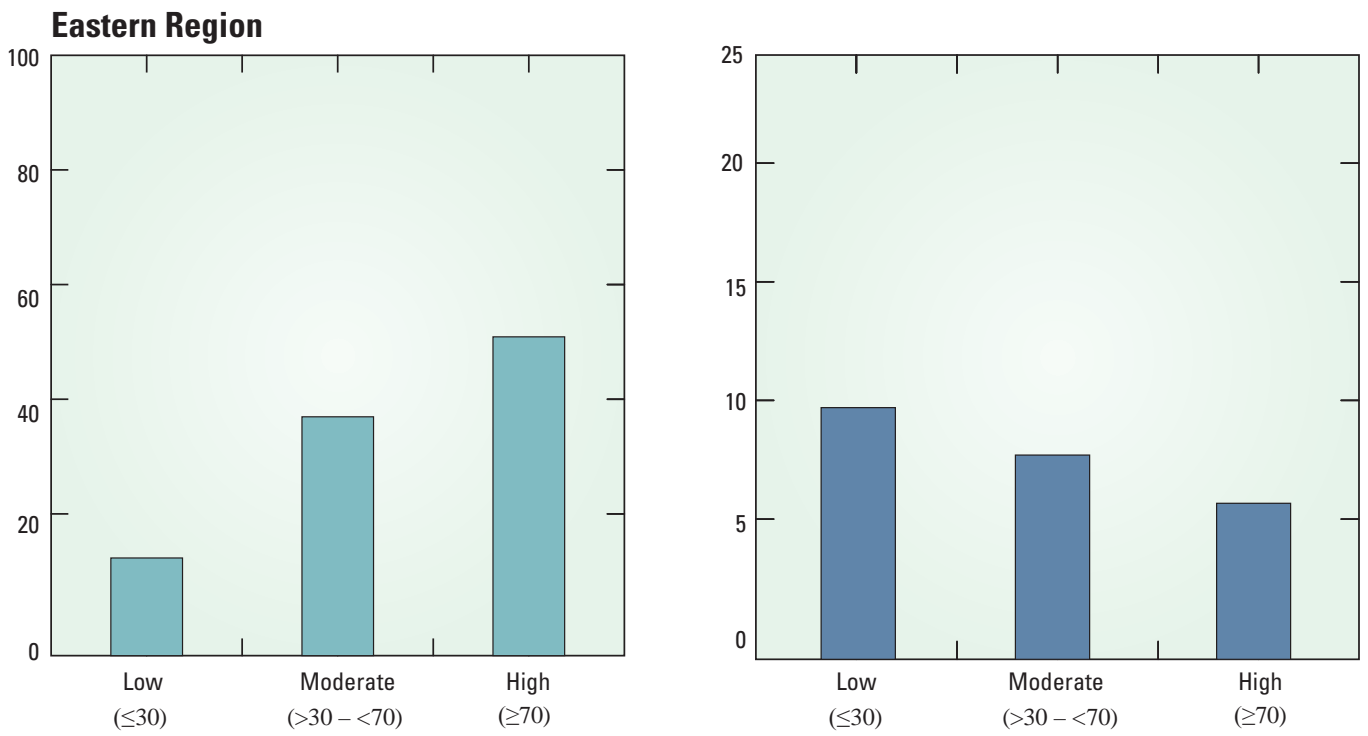

Agricultural intensity category 


\section{Low Dissolved-0xygen Concentrations Lead to Poor Biological Condition}

Oxygen depletion due to respiration and the decomposition of aquatic vegetation is one of the greatest nutrientrelated stressors to biological communities (Cooper, 1993). The magnitude of the fluctuation and duration of low oxygen conditions influence the extent of stress on aquatic communities. Daily dissolved-oxygen fluctuations of $6.0 \mathrm{mg} / \mathrm{L}$ or more are detrimental to biological communities (Miltner, 2010). Stalker Creek, an Idaho trout stream in the Snake River area, can develop excessive aquatic plant growth during the summer growing season. Even though this stream has only a moderate amount of agricultural activity in the watershed (Agricultural Intensity Index of 55), this groundwater-fed stream with its clear water, open channel, and adequate nutrient concentrations provides ideal conditions for aquatic plant growth.

This stream also is susceptible to low dissolved oxygen because its low gradient and deep channel provide less reaeration opportunity than a shallow, high-gradient stream. These conditions can produce undesirable dissolvedoxygen fluctuations of more than $10 \mathrm{mg} / \mathrm{L}$ between daytime and nighttime (fig. 6-6). Dissolved oxygen in early morning hours decreases to less than $6.0 \mathrm{mg} / \mathrm{L}$, which is considered the minimum desirable concentration to protect sensitive cold-water organisms such as trout (Idaho Department of Environmental Quality, 2011). This condition can result in altered algae and invertebrate condition with O/E scores around 60 percent of expected conditions. Elevated summer air temperatures exacerbate the problem because increased water temperatures make oxygen less soluble in water. The lack of oxygen available to fish along with increased metabolic requirements with increasing water temperatures has resulted in summer fish kills in this stream. The algae and invertebrate communities at this site, with scores of 55 and 60 percent, respectively, show an altered biological condition during July 2007. The Nature Conservancy and agricultural landowners are working together on a local watershed enhancement program on agricultural lands to reduce sediment and nutrients entering Stalker Creek.

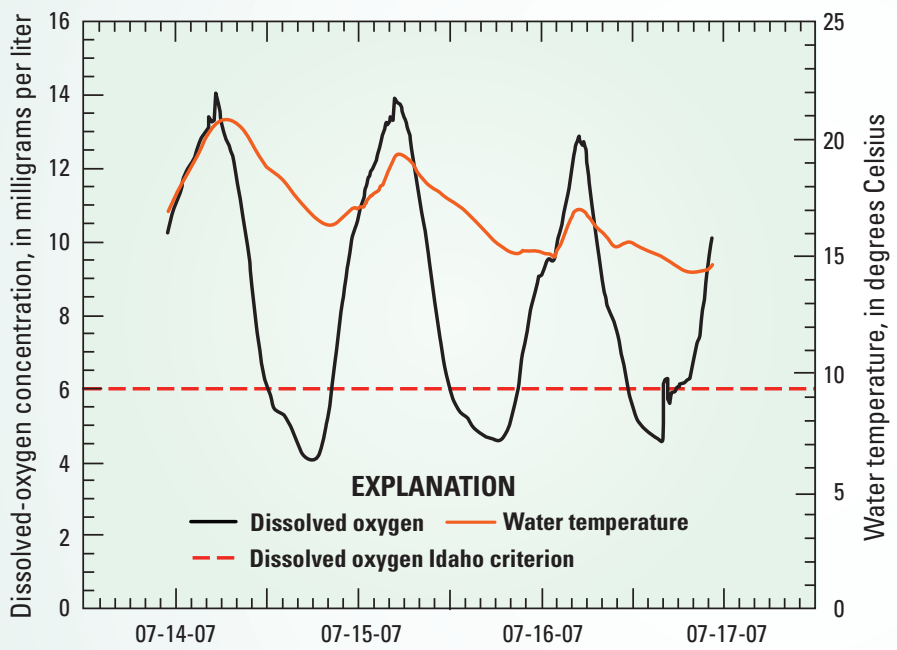

Figure 6-6. Daily dissolved-oxygen concentration in Stalker Creek decreased to less than the Idaho criterion of 6.0 milligrams per liter (Idaho Department of Environmental Quality, 2011) during summer nighttime.
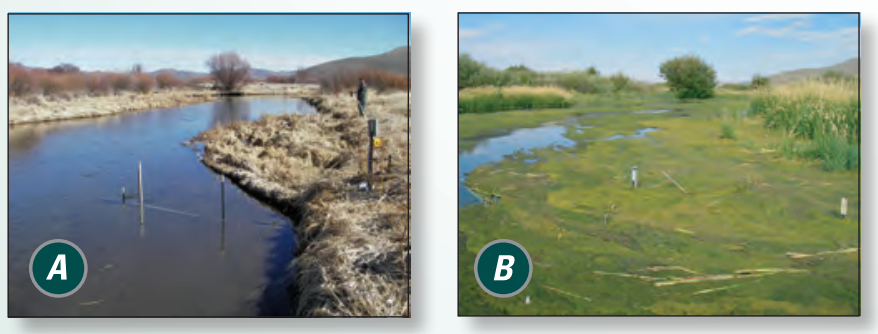

Stalker Creek, a spring-fed stream in Idaho $(A)$, develops excessive plant growth $(B)$ during spring and summer as a result of low gradient, ample sunlight, and adequate nutrients from groundwater sources. This condition can lead to undesirable dissolved-oxygen concentrations that alter biological communities. The excessive plant growth reduces the desirability for recreational uses, such as swimming and fishing. Photographs taken by Christopher Mebane, U.S. Geological Survey; $(A)$ March 15, 2007, (B) August 20, 2007. 


\section{Role of Habitat on Biological Condition}

Biological condition decreases with increased agriculture in the riparian buffer.

Biological condition of algae and invertebrates were negatively correlated with the amount of agricultural land in the 100-m riparian buffer (fig. 6-7). Biological condition rapidly decreased as agricultural land in the 100-m stream riparian buffer increased to about 20 percent and then leveled off, suggesting there may be a point beyond which biological communities do not change. On average, streams with less than 20 percent agricultural land in the stream buffer had 22-28 percent higher invertebrate and algae community conditions than streams with more agricultural land in the buffer. Streamside vegetation is important because it can remove nutrients from runoff and shallow groundwater, and reduce bank erosion and the amount of overland runoff carrying sediment into streams. The wide range in biological condition at various levels of agriculture in the riparian buffer is due to other factors that can influence biological condition, including chemical loading, diversions, and channelizations.

Biological condition decreases with increases in fine-grained substrate, be it natural or anthropogenic.

Stream substrate- the material on the streambed-is one of the critical habitat features affecting biota because it provides the home where benthic invertebrates live. Generally, there are more types of invertebrates when a stream bottom consists of a mixture of gravel and cobble; when sediments - especially fine-grained sediment-are deposited on rocky substrate, the living spaces are filled in, which reduces important habitat. For example, in the Central Region, the biological condition of invertebrates decreased by about 50 percent as the amount of fine substrate increased (fig. 6-8). Although some streams naturally have fine-grained substrate, agricultural practices contribute sediment to streams due to soil erosion and streambank destabilization. Agricultural best management practices that reduce these sediment inputs have been shown to improve biological condition in streams. These practices also reduce the loadings of phosphorus, as phosphorus compounds are often bound to fine-grained sediments.

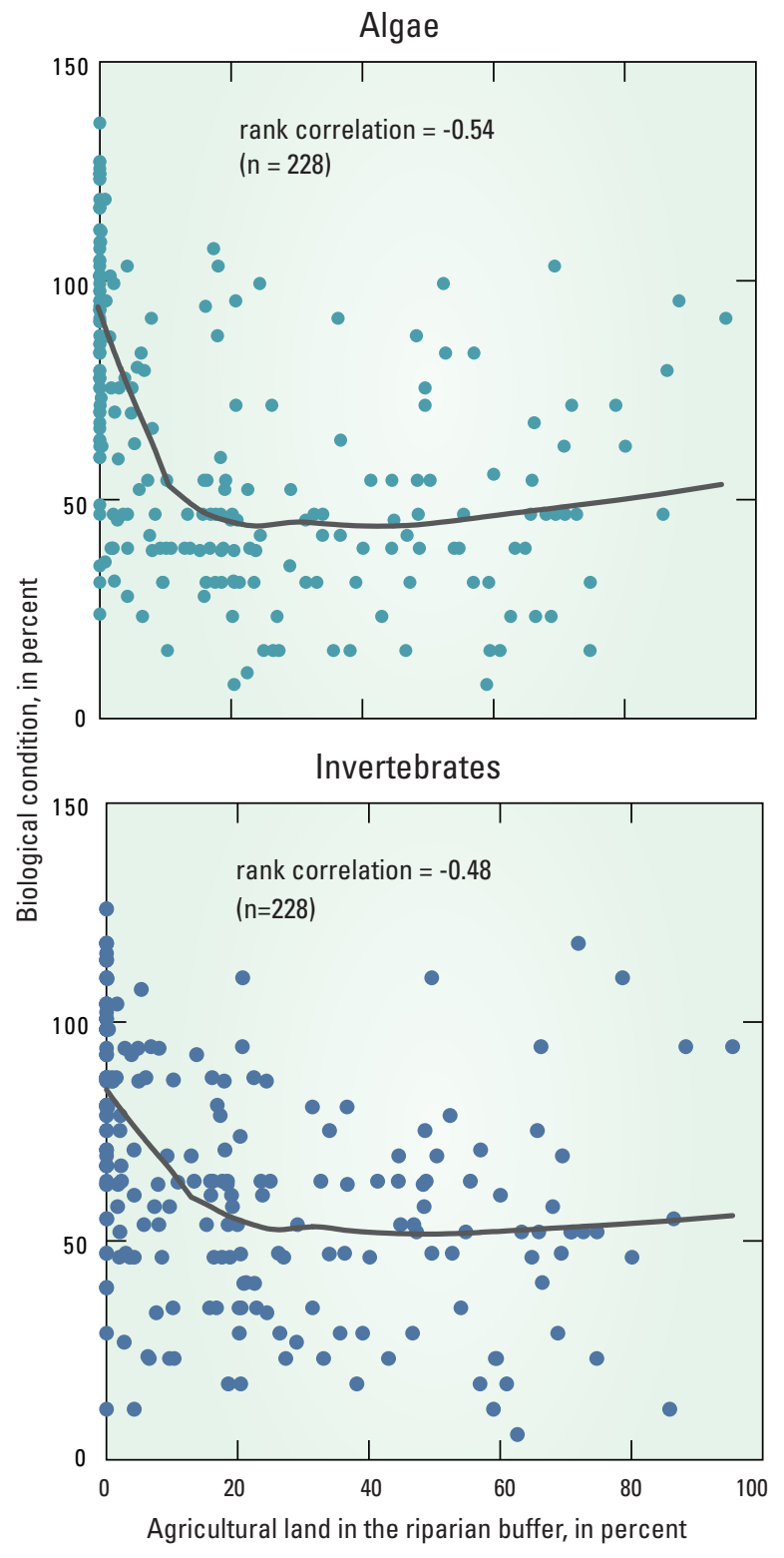

Figure 6-7. A relatively small amount of agricultural activity in the stream riparian area can have negative effects on the biological condition of algae and invertebrates. Streams with extensive riparian buffers tend to have high biological condition, whereas streams lacking riparian buffers tend to have low biological condition. 
Elk Creek, Ohio

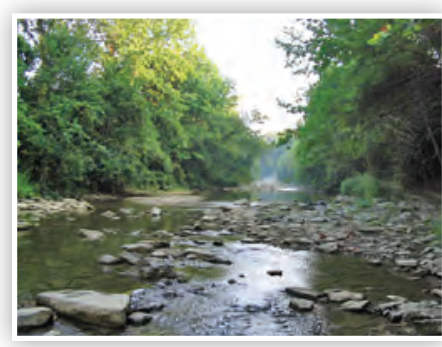

Streams with low fine-grained substrates, such as Elk Creek, often have high biological condition

Figure 6-8. Biological condition decreases as the percentage of fine-grained substrate increases, often as a result of destabilization of streambanks or soil erosion from agricultural fields.

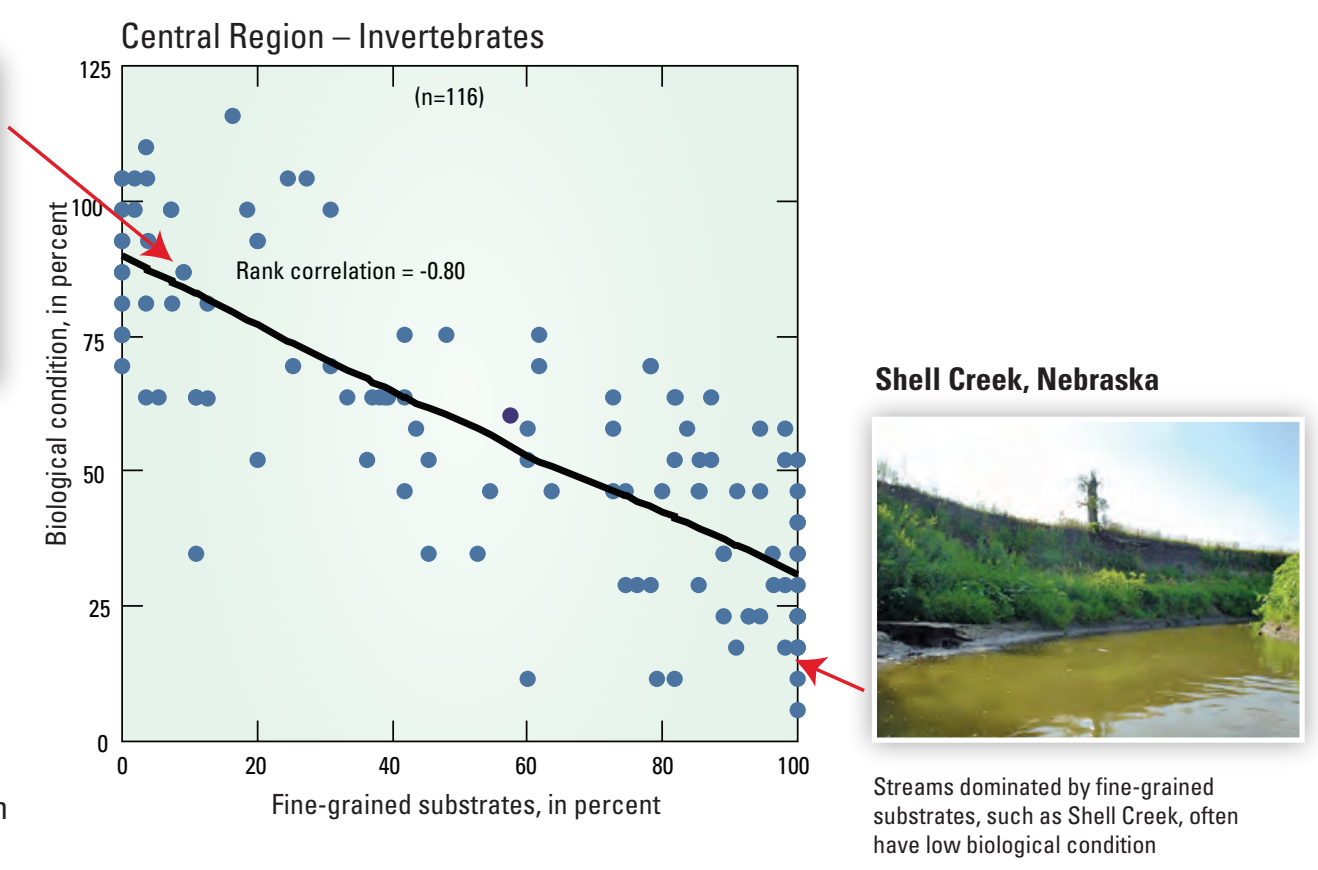

Habitat commonly has a greater influence on biological condition than nutrients.

Understanding the relative influence of stream habitat is critical for assessing potential nutrient effects on biological condition. Statistical models were used to determine which factors explain the most variability in the invertebrate community condition. Stream habitat was the most influential factor, explaining greater than 50 percent of the variation in invertebrate community condition in six of the eight areas. In contrast, nutrients explained invertebrate community condition in three areas (Upper Mississippi, Snake River, and Columbia Plateau), and were a more dominant influence than habitat in only the Columbia Plateau. Percentage of fine-grained substrate and instream habitat cover (for example, large wood, boulders, and macrophyte beds) were two of the dominant habitat features that explained biological condition overall.

Habitat and nutrients both influenced invertebrate community condition in the Columbia Plateau and Snake River areas (fig. 6.9). Habitat alone explained invertebrate communities in the White-Miami, with neither total phosphorus nor total nitrogen being important in the statistical model. Biological condition of invertebrates had no significant association with nutrient concentrations here because concentrations of total nitrogen and total phosphorus far exceeded levels required by aquatic life, and therefore were not limiting.

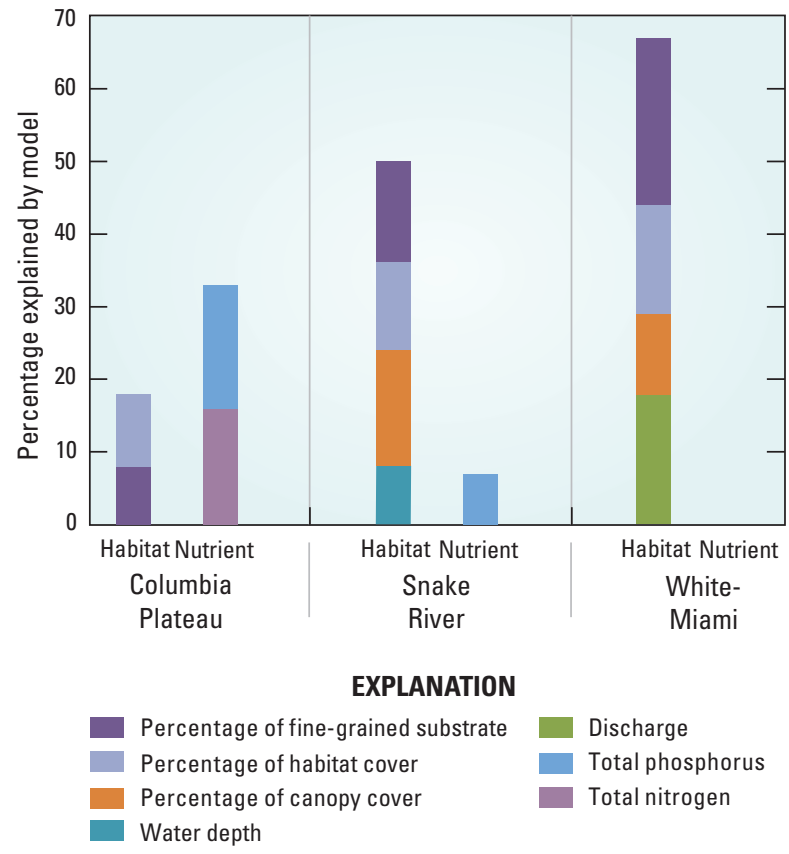

Figure 6-9. In the Columbia Plateau, nutrients accounted for a larger percentage of invertebrate community condition than habitat, whereas in the Snake River area, habitat was more important than nutrients. In contrast, in the White-Miami, nutrients did not explain any of the invertebrate condition; however, both nitrogen and phosphorus were well above biological requirements and therefore still influence the communities that are present in those streams. 


\section{Understanding the Connections Between Agricultural Land Use, Nutrients, and Habitat and Biological Condition}

Although nutrients have a positive and negative influence on biological communities in streams, the connections, or pathways, linking land use, riparian and stream habitat, nutrients and biological response are not well understood. The causal pathways that link agricultural land use to biological condition likely involves multiple land-use attributes that influence instream habitat and nutrients, which then influence biological communities (Munn and others, 2002; Waite and others, 2010). Structural Equation Modeling is an effective tool for evaluating the complex interactions of multiple factors and biological response (see "What is Structural Equation Modeling?"). For this analysis, data from the eight areas were used to develop regional models (Riseng and others, 2011).

The initial step was to construct a conceptual model that included factors that influence biological condition (land use, nutrients, and habitat) and how they interact based on existing literature and knowledge of the system (fig. 6-10A). Cropland was expected to indirectly affect invertebrate community

\section{What is Structural Equation Modeling?}

Structural Equation Modeling (SEM) is a statistical technique to test and estimate the strength of causal relations. It is an effective tool for evaluating the complex interactions of multiple factors, such as habitat, water chemistry, and biological response. SEM uses measured and derived variables. A measured variable is one that was collected from the field or generated from a geographic information system, whereas a derived variable is constructed from the statistical correlations among two or more measured variables. The initial step is to develop a conceptual model that shows the relationships among measured and derived variables based on existing literature, with the SEM then used to determine if the study data statistically supports the conceptual model. SEM has numerous features that make it ideal for examining the role of nutrients in agricultural streams and how nutrients are influenced by physical factors in the watershed, riparian strip, and stream. Additional detail on the Structural Equation Model is presented in Riseng and others (2011). condition through effects on coarse substrate, habitat quality, particulate-bound chemicals (as in total phosphorus) and dissolved chemicals (as in inorganic nitrogen). Some of the variables in the conceptual model are derived variables, meaning combinations of measured variables. For example, in the following list, the derived variables (left side) are statistical representations of the measured variables (right side):

Coarse substrate $=$ average sediment size, percentage of sediment embedded

Habitat quality = stream gradient, shear stress, percentage of riffle/pool

Particulate-bound chemicals $=$ total phosphorus, suspended sediment, organic carbon

Dissolved chemicals $=$ conductivity, dissolved inorganic nitrogen

Invertebrate community condition = combined number of mayfly, stonefly, and caddisfly taxa (EPT richness), number of pollution tolerant taxa, percentage of taxa considered pollution intolerant.

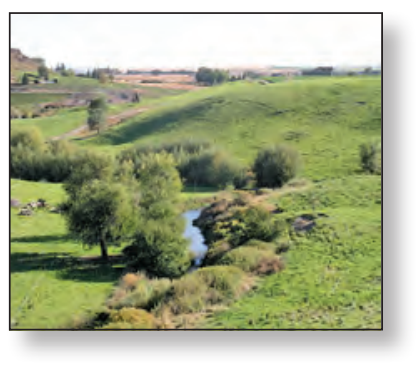

Irrigation and rangeland combined with minimal riparian buffers contribute to the elevated levels of nutrients in western agricultural streams like Billngsley Creek, Idaho. Photograph by Christopher Mebane, U.S. Geological Survey.

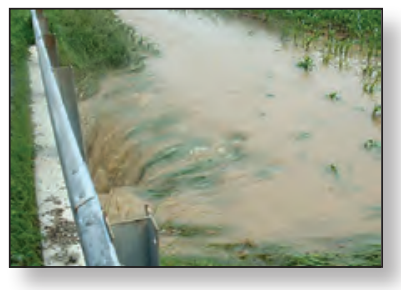

Agricultural runoff in lowa.

Photograph by John Wilson, U.S. Geological Survey, 2003.

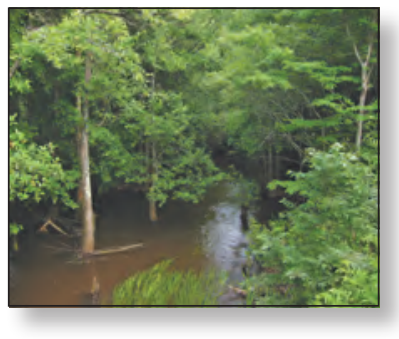

Example of riparian wetlands in the Eastern Region at a stream in Georgia. Photograph by M.D. Munn, U.S. Geological Survey, June 2, 2003. 
The validity and importance of each of the causal links in the conceptual model was evaluated for agricultural streams in the Western, Central, and Eastern Regions. The variables with the strongest correlations identify the most important factors affecting invertebrate community condition.

\section{Western Region}

In the Western Region, an increase in the amount of cropland in the watershed was linked to an increase in dissolved chemicals (for example, dissolved inorganic nitrogen), which resulted in a decrease in invertebrate community condition (fig. 6-10B). Both Western Region areas rely partially on extensive surface-water irrigation, which can be a source and transport mechanism of dissolved chemicals, including nitrogen (Clark and others, 1998, Williamson and others, 1998). In contrast, particulate-bound chemicals (for example, total phosphorus) can have a positive influence on invertebrate community condition in areas where low phosphorus availability limits biological organisms. Forested wetland riparian buffers, which were not common in the West, also were associated with a decrease in both particulate and dissolved chemicals, which includes total phosphorus and dissolved inorganic nitrogen. Cropland in the watershed did decrease coarse substrate, likely due to fines contributed by soil erosion. The negative influence of increased fines on benthic invertebrates likely diminished the normally positive influence of coarse substrate on invertebrate communities. Water resource managers in the West could improve biological condition by reducing the transport of dissolved chemicals, as in nitrogen, to streams.

\section{Central Region}

In the Central Region, cropland has its largest negative influence on invertebrate community condition by decreasing habitat quality and increasing particulate-bound chemicals, which decreased invertebrate community condition (fig. 6-10C). While increases in cropland also directly increased dissolved chemicals, invertebrate community condition was not influenced. The lack of a significant negative influence by dissolved chemicals likely is due to the consistently high concentrations in most of the streams in the Central Nebraska, White-Miami, and Upper Mississippi. Forested wetlands in the riparian buffer had no significant influence on particulate or dissolved chemicals. Water resource managers in the Central Region could improve biological condition by managing both cropland and/or stream habitat to reduce transport of particulate chemicals, as in phosphorus, to streams.

\section{Eastern Region}

In the Eastern Region, as in the other two regions, increased cropland was associated with an increase in dissolved chemicals; however, dissolved chemicals did not influence invertebrate community condition. The model did indicate that riparian forested wetlands played a dominant role in decreasing both dissolved and particulate-bound chemicals; however, particulate chemicals were still sufficiently high to have a negative influence on invertebrate community condition (fig. 6-10D). Numerous studies have suggested that intact wetlands and riparian buffers can have beneficial effects on biological communities by filtering out fine sediments and chemicals. Water resource managers in the Eastern Region could enhance biological condition by protecting forested wetlands in the riparian systems, which reduce phosphorus and sediment transport to streams.

In summary, invertebrate community condition is influenced by complex interactions of land use, riparian buffer, instream habitat, and nutrients, with the dominant controlling factors varying by region. The amount of cropland in a watershed was the strongest positive (increasing) predictor of nutrient concentrations in streams in all three region. In the Central and Eastern Regions, the amount of particulate-bound chemicals (total phosphorus and suspended sediment) had the strongest negative influence on invertebrate community condition; whereas, invertebrate community condition in the Western Region was influenced by dissolved chemicals. Forested riparian wetlands played an important role in improving water quality, which further supports protecting or enhancing riparian habitat along streams. 


\section{A. Conceptual model}

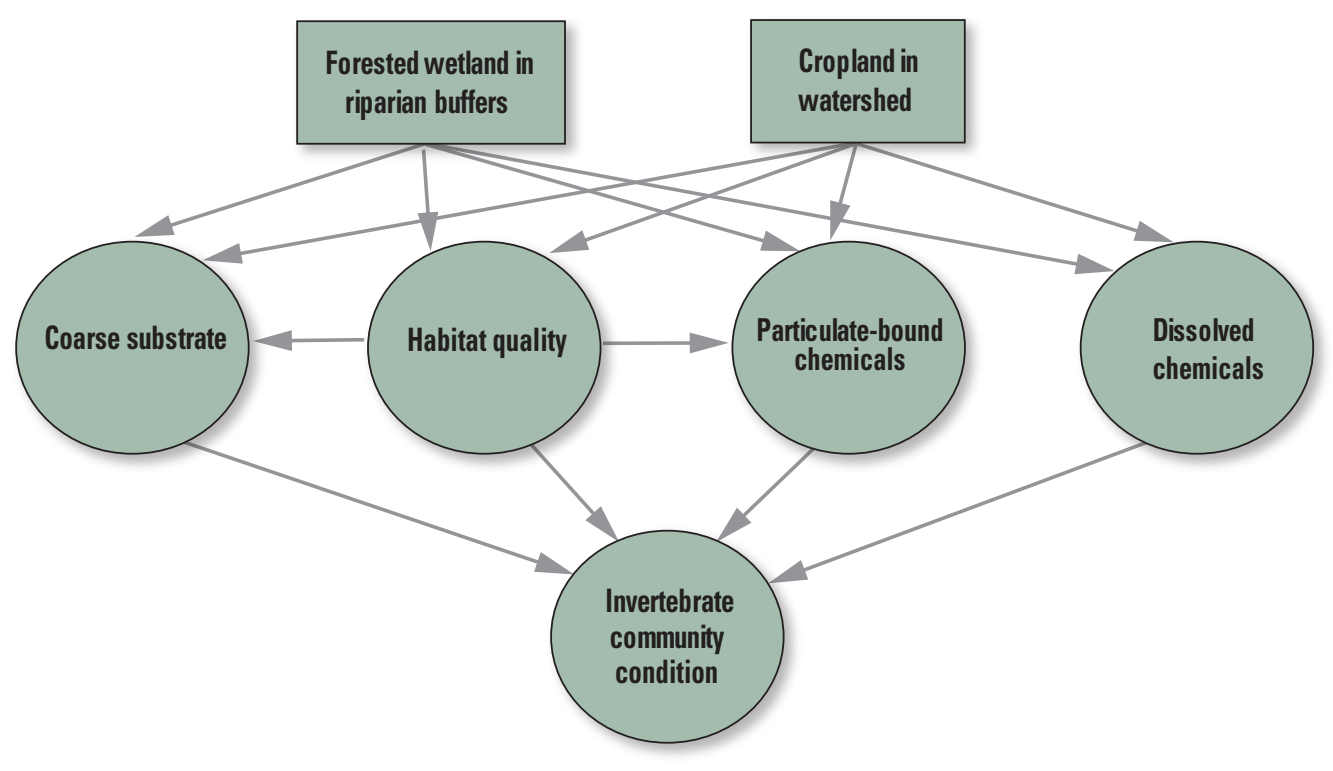

\section{B. Western Region agricultural streams}

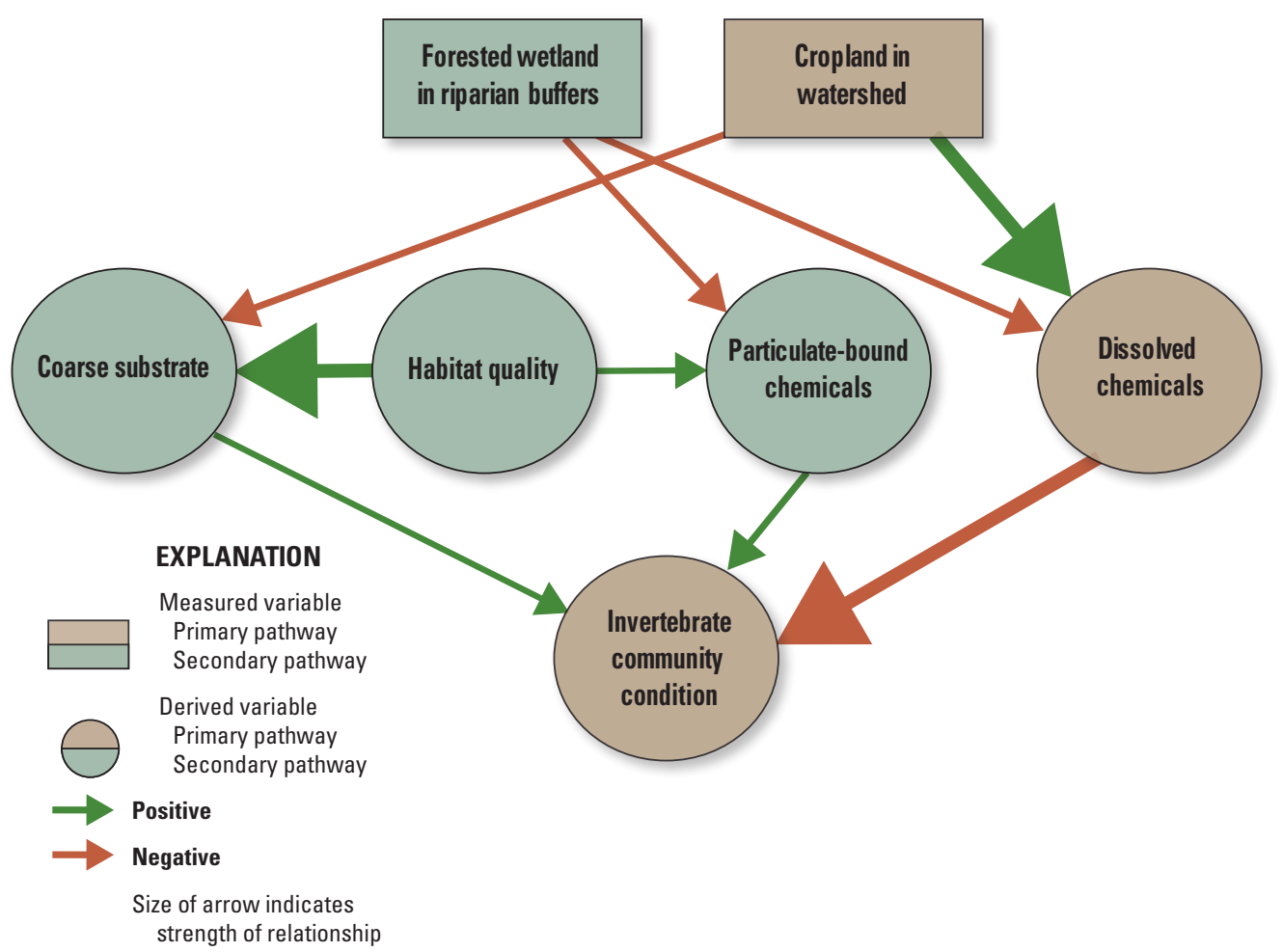

Figure 6-10. Structural Equation Modeling (SEM) is a statistical technique that tests how well the measured data agree with the conceptual model. $(A)$ Conceptual SEM designed to determine interactions of multiple variables that influence invertebrate community condition. $(B)$ In the Western Region, the amount of cropland in the watershed was linked to increased dissolved chemicals, which resulted in a decrease in invertebrate community condition. $(C)$ In the Central Region, cropland had its largest negative influence on invertebrate community condition by decreasing habitat quality and increasing particulate-bound chemicals. (D) In the Eastern Region, increased forested wetlands in the riparian buffer decreased both dissolved and particulate-bound chemicals; however, particulatebound chemicals were still associated with a decrease in invertebrate community condition. 


\section{Central Region agricultural streams}

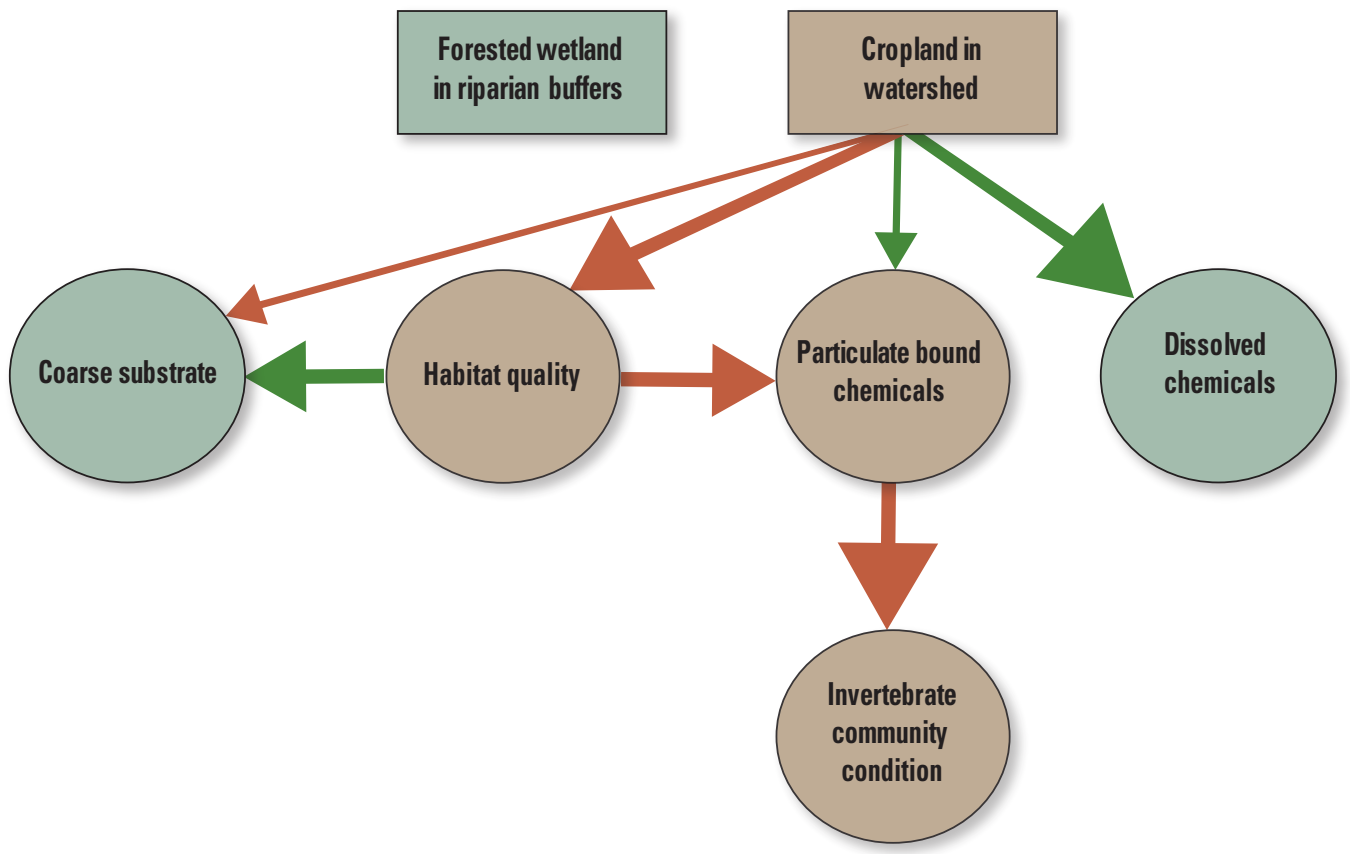

\section{Eastern Region agricultural streams}

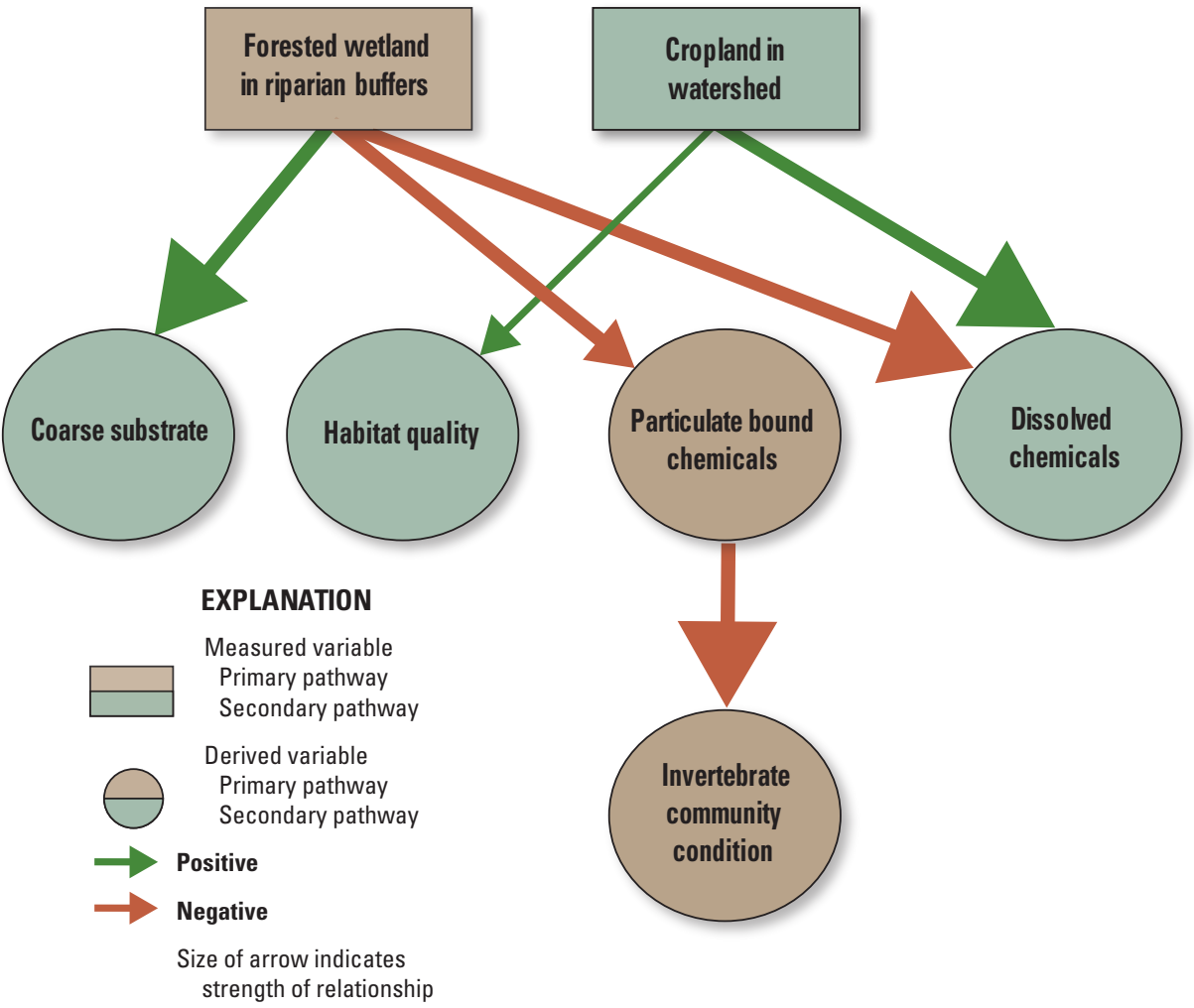

Figure 6-10.-Continued. 


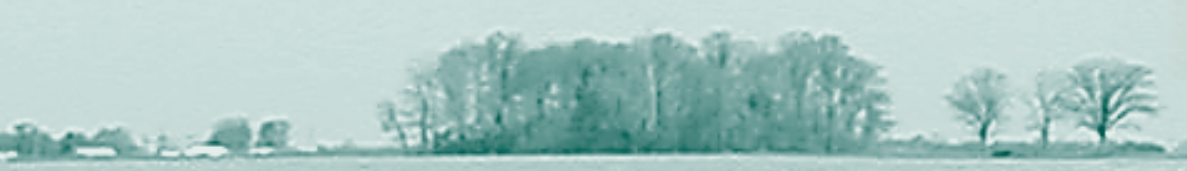

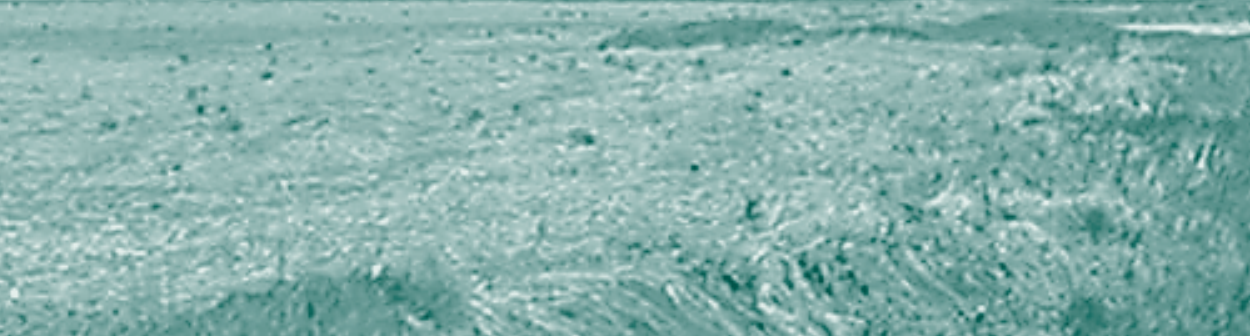

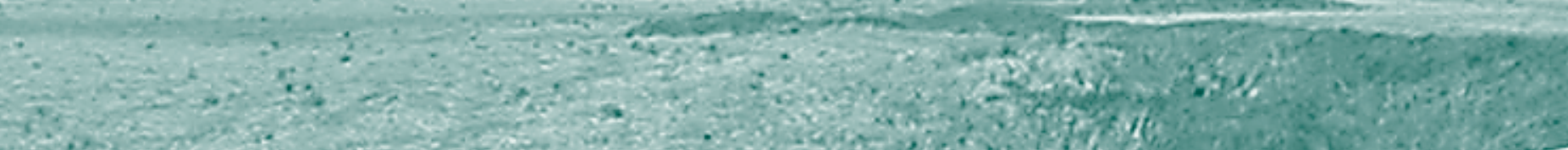

(3.

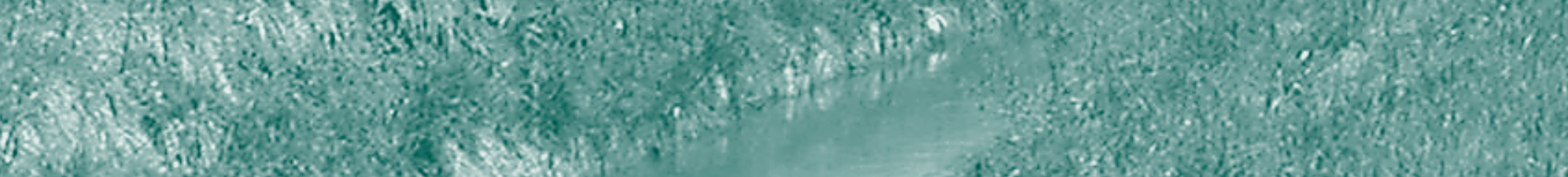
(x)

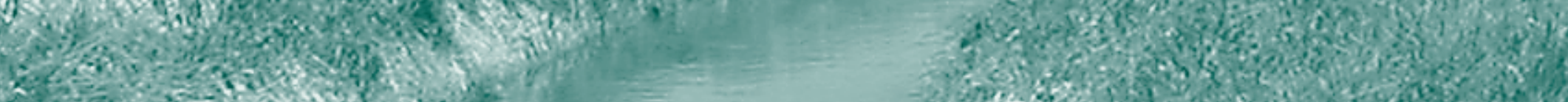
W.

1.:

(2)

16. 5

(1)

(2)

(1)

4.

(x)

Xin

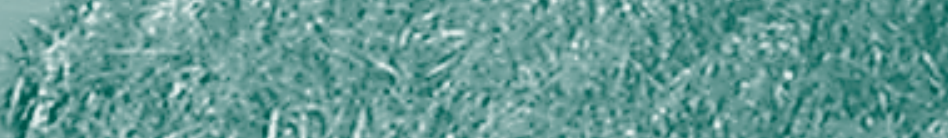
10. (1)

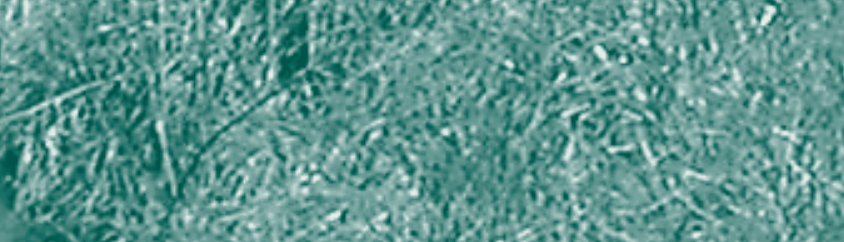
(3. 2.

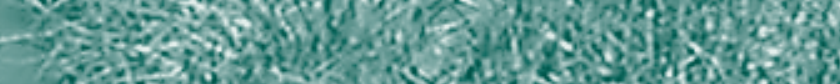
1.5:

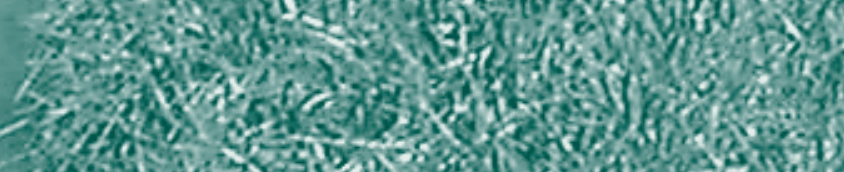
7. 1. X

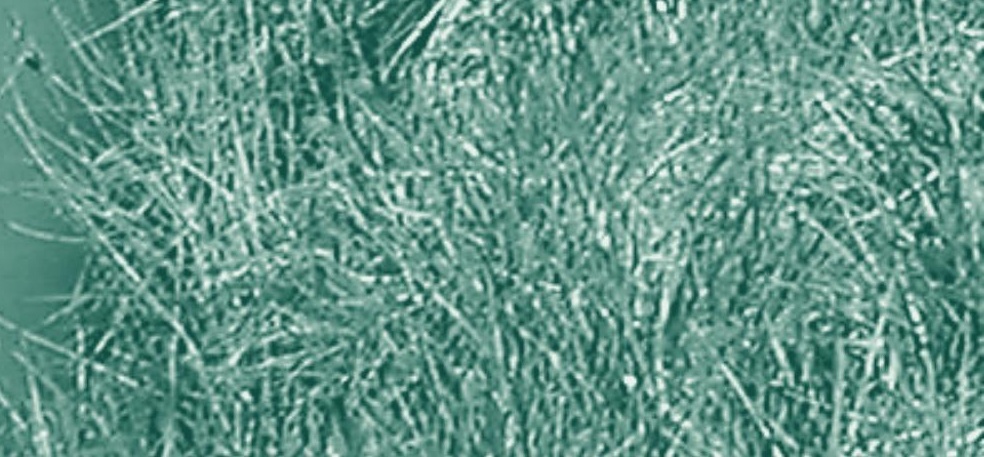


Baker, N.T., Stone, W.W., Wilson, J.T., and Meyer, M.T., 2006, Occurrence and transport of agricultural chemicals in Leary Weber Ditch Basin, Hancock County, Indiana, 2003-04: U.S. Geological Survey Scientific Investigations Report 2006-5251, 44 p., https://pubs.usgs.gov/sir/2006/5251/.

Bales, J.D., and Nardi, M.R., 2007, Automated routines for calculating whole-stream metabolismTheoretical background and user's guide: U.S. Geological Survey Techniques and Methods book 4, chap. 2, 33 p., https://pubs.water.usgs.gov/tm4c2/.

Belton, T.J., Ponader, K.C., and Charles, D.F., 2006, Trophic diatom indices (TDI) and the development of site-specific nutrient criteria: Trenton, New Jersey, New Jersey Department of Environmental Protection, Division of Science Research and Technology, 15 p.

Bernot, M.J., Sobota, D.J., Hall, R.O., Mulholland, P.J., Dodds, W.K., Webster, J,R., Tank, J.L., Ashkenas, L.R., Cooper, L.W., Dahm, C.L., Gregory, S.V., Grimm, N.B., Hamilton, S.K., Johnson, S.L., McDowell, W.H., Meyer, J.L., Petersen, Bruce, Poole, G.C., Valett, H.M., Arango, Clay, Beaulieu, J.J., Burgin, A.J., Crenshaw, Chelsea, Helton, A.M., Johnson, Laura, Merriam, Jeff, Niederlehner, B.R., O’Brien, J.M., Potter, J.D., Sheibley, R.W., Thomas, S.M., and Wilson, Kym, 2010, Inter-regional comparison of land-use effects on stream metabolism: Freshwater Biology, 55, p. 1,874-1,890.

Biggs, B.J.F., 1996, Patterns in benthic algae in streams, in Stevenson, R.J., Bothwell, M.L., and Lowe, R.L., eds., Algal ecology freshwater benthic ecosystems: New York, Academic Press, p. 31-56.

Biggs, B.J.F., and Kilroy, C., 2000, Stream periphyton monitoring manual: National Institute of Water and Atmospheric Research, Prepared for New Zealand Ministry for the Environment, $226 \mathrm{p}$.

Brightbill, R.A., and Frankforter, J.D., 2010, Environmental and biological data for assessment of the nutrient enrichment effects on agricultural stream ecosystems, 2006-08-A project of the National Water-Quality Assessment Program: U.S. Geological Survey Data Series 517, 12 p., https://pubs.usgs.gov/ ds $/ 517 /$.
Brightbill, R.A., and Munn, M.D., 2008, Environmental and biological data of the nutrient enrichment effects on stream ecosystems project of the National Water Quality Assessment Program, 2003-04: U.S. Geological Survey Data Series 345, 13 p., https:// pubs.usgs.gov/ds/345/.

Brink, C.M., and Moore, J.N., 1996, Diel variation of trace metals in the Upper Clark Fork River, Montana: Environmental Science and Technology, v. 30, p. $1,953-1,960$.

Burkart, M.R., Simpkins, W.W., Morrow, A.J., and Gannon, J.M., 2004, Occurrence of total dissolved phosphorus in unconsolidated aquifers in Iowa: Journal of the American Water Resource Association, v. 40, p. $827-834$.

Carignan, R., and Kalff, J., 1980, Phosphorus sources for aquatic weeds - Water or sediments?: Science, v. 207 , no. 4434 , p. $987-989$.

Carlisle, D.M., Falcone, J., and Meador, M.R., 2009, Predicting the biological use of geospatial indicators of natural and anthropogenic characteristics of watersheds: Environmental Monitoring and Assessment, v. 151, p. 143-160.

Carlisle, D.M., and Meador, M.R., 2007, A predictive model for the biological condition of macroinvertebrate assemblages in eastern U.S. streams: Journal of the American Water Resources Association, v. 43, p. 1,194-1,207.

Caskey, B.J., and Frey, J.W., 2009, Biologicalcommunity composition in small streams and its relations to habitat, nutrients, and land use in agriculturally dominated landscapes in Indiana and Ohio, 2004, and implications for assessing nutrient conditions in Midwest streams: U.S. Geological Survey Scientific Investigations Report 2009-5055, 21 p., CD-ROM containing 4 appendixes.

Chambers, P.A., DeWreed, R.E., Irlandi, E.A., and Vandermeulen, H., 1999, Management issues in aquatic macrophyte ecology - A Canadian perspective: Canadian Journal of Botany, v. 77, no. 4, p. 471-487, https://doi.org/10.1139/b99-092. 
Chambers, P.A., Prepas, E.E., Bothwell, M.L., and Hamilton, H.R., 1989, Roots versus shoots in nutrient uptake by aquatic macrophytes in flowing waters: Canadian Journal of Fisheries and Aquatic Sciences, v. 46 , no. 3, p. 435-439.

Clark, G.M., Maret, T.R., Rupert, M.G., Maupin, M.A., Low, W.H., and Ott, D.S., 1998, Water quality in the Upper Snake River Basin, Idaho and Wyoming, 1992-95: U.S. Geological Survey Circular 1160, 35 p., https://pubs.usgs.gov/circ/circ1160/.

Corkum, L.D., 1996, Responses of chlorophyll-a, organic matter, and macroinvertebrates to nutrient additions in rivers flowing through agricultural and forested land: Archives Hydrobiologia, v. 136, no. 4, p. 391-411.

Cooper, C.M., 1993, Biological effects of agriculturally derived surface water pollution on aquatic systems-A review: Journal of Environmental Quality, v. 22, p. 402-408.

Correll, D.L., 1998, The role of phosphorus in the eutrophication of receiving waters-A review: Journal of Environmental Quality, v. 27, p. 261-266.

Denver, J.M., Tesoriero, A.J., and Barbaro, J.R., 2010, Trends and transformation of nutrients and pesticides in a Coastal Plain Aquifer System, United States: Journal of Environmental Quality, v. 39, p. 154-167.

Dodds, W.K., Smith, V.H., and Lohman, K., 2002, Nitrogen and phosphorus relationships to benthic algal biomass in temperature streams: Canadian Journal of Fisheries and Aquatic Sciences, v. 59, p. $865-874$.

Dodds, W.K., Bouska, W.W., Eitzmann, J.L., Pilger, T.J., Pitts, K.L., Riley, A.J., Schloesser, J.T., and Thornbrugh, D.J., 2009, Eutrophication of U.S. freshwaters-Analysis of potential economic damages: Environmental Science and Technology, v. 43 , no. 1 , p. $12-19$.

Domagalski, J.L., and Johnson, H.M., 2011, Subsurface transport of orthophosphate in five agricultural watersheds, USA: Journal of Hydrology, v. 409, no. 1-2, p. 157-171, http://doi.org/10.1016/j. jhydrol.2011.08.014.
Dubrovsky, N.M., Burow, K.R., Clark, G.M., Gronberg, J.M., Hamilton, P.A., Hitt, K.J., Mueller, D.K., Munn, M.D., Nolan, B.T., Puckett, L.J., Rupert, M.G., Short, T.M., Spahr, N.E., Sprague, L.A., and Wilber, W.G., 2010, The quality of our Nation's waters-nutrients in the Nation's streams and groundwater, 1992-2004: U.S. Geological Survey Circular 1350, 174 p., https:// pubs.usgs.gov/circ/1350/.

Duff, J.H., Tesoriero, A.J., Richardson, W.B., Strauss, E.A., and Munn, M.D., 2008, Whole-stream response to nitrate loading in three streams draining agricultural landscapes: Journal of Environmental Quality, v. 37, p. 1,133-1,144.

Edmondson, W.T., 1972, Nutrients and phytoplankton in Lake Washington, in Likens, G.E., ed., Nutrients and eutrophication: Lawrence, Kansas, American Society of Limnology and Oceanography, p. 172-188.

Feminella, J.W., and Hawkins, C.P., 1995, Interaction between stream herbivores and periphyton-A quantitative analysis of past experiments: Journal of the North American Benthological Society, v. 14, no. 4 , p. $465-509$.

Fenneman, N.M., and Johnson, D.W., 1946, Physical divisions of the United States: Washington, D.C., U.S. Geological Survey, scale 1:7,000,000, 1 sheet.

Fitzpatrick, F.A., Waite, I.R., D'Arconte, P.J., Meador, M.R., Maupin, M.A., and Gurtz, M.E., 1998, Revised methods for characterizing stream habitat in the National Water-Quality Assessment Program: U.S. Geological Survey Water-Resources Investigations Report 98-4052, 67 p., https://pubs.usgs.gov/wri/ wri984052/.

Frankforter, J.D., Weyers, H.S., Bales, J.D., Moran, P.W., and Calhoun, D.L., 2009, The relative influence of nutrients and habitat on stream metabolism in agricultural streams: Environmental Monitoring and Assessment, v. 168, p. 461-479, http://doi. org/10.1007/s10661-009-1127-y.

Galloway, J.N, Schlesinger, W.H., Levy H., II, Michaels, A., and Schnoor, J.L., 1995, Nitrogen fixation-Anthropogenic enhancementenvironmental response: Global Biogeochemical Cycles, v. 9, p. 235-252. 
Graham, J.L, Loftin, K.A., Meyer, M.T., and Ziegler, A.C., 2010, Cyanotoxin mixtures and taste-andodor compounds in cyanobacterial blooms from the Midwestern United States: Environmental Science and Technology, v. 44, p. 7,361-7,368.

Herlihy, A.T., and Sifneos, J.C., 2008, Developing nutrient criteria and classification schemes for wadeable streams in the conterminous US: Journal of the North American Benthological Society, v. 27, p. $932-948$.

Hill, W.R., and Fanta, S.E., 2008, Phosphorus and light colimit periphyton growth at subsaturating irradiances: Freshwater Biology, v. 53, p. 215-225.

Holman, I.P., Howden, N.J.K., Bellamy, P., Willby, N., Whelan, M.J., and Rivas-Casado, M., 2010, An assessment of the risk to surface water ecosystems of groundwater P in the U.K. and Ireland: Science of the Total Environment, v. 408, p. 1,847-1,857.

Homer, C., Dewitz, J., Fry, J., Coan, M., Hossain, N., Larson, C., Herold, N., McKerrow, A., VanDriel, J.N., and Wickham, J., 2007, Completion of the 2001 National Land Cover Database for the conterminous United States: Photogrammetric Engineering and Remote Sensing, v. 73, no. 4, p. 337-341.

Horner, R.R., Welch, E.B., and Veenstra, R.B., 1983, Development of nuisance periphyton algae in laboratory streams in relation to enrichment and velocity, in Wetzel, R.G., ed., Periphyton of freshwater ecosystems: Dr. W. Junk Publishers, The Hague, The Netherlands, p. 121-134.

Howarth, R., Anderson, D., Cloern, J., Hopkinson, C., LaPointe, B., Malone, T., Marcus, N., McGlathery, K., and Sharpley, A., 2000, Nutrient pollution of coastal rivers, bays, and seas: Issues in Ecology, v. 7, p. $1-15$.

Idaho Department of Environmental Quality, 2011, Idaho Administrative Code, Water Quality Standards, IDAPA 58.01.02, accessed February 23, 2011, at http://adminrules.idaho.gov/rules/current/58/0102.pdf.
Jarvie, H.P., Sharpley, A.N., Withers, P.J.A., Scott, J.T., Haggard, B.E., and Neal, Colin, 2013, Phosphorus mitigation to control river eutrophication-Murky waters, inconvenient truths, and 'postnormal' science: Journal of Environmental Quality, v. 42, p. 295-304, http://doi.org/10.2134/jeq2012.0085.

Johnson, M.R., and Zelt, R.B., 2005, Protocols for mapping and characterizing land use/land cover in riparian zones: U.S. Geological Survey Open-File Report 2005-1302, 16 p., https://pubs.usgs.gov/ of/2005/1302/.

Justus, B.G., Petersen, J.C., Femmer, S.R., Davis, J.V., and Wallace, J.E., 2010, A comparison of algal lowlevel nutrient enrichment in wadeable Ozark streams: Ecological Indicators, v. 10, no. 3, p. 627-638.

Kleinman, P.J.A., Sharpley, A.N., Buda, A.R., McDowell, R.W., and Allen, A.L., 2011, Soil controls of phosphorus in runoff-Management barriers and opportunities: Canadian Journal of Soil Science, v. 91, p. 329-338, http://doi.org/10.4141/cjss09106.

Lee, K.E., Lorenz, D.L., Petersen, J.C., and Greene, J.B., 2012, Seasonal patterns in nutrients, carbon, and algal responses in wadeable streams within three geographically distinct areas of the United States, 2007-08: U.S. Geological Survey Scientific Investigations Report 2012-5086, 55 p., https://pubs. usgs.gov/sir/2012/5086/.

Lenat, D.R., 1988, Water quality assessment of streams using a qualitative collection method for benthic macroinvertebrates: Journal of the North American Benthological Society, v. 7, p. 222-233.

Majewski, M.S., and Capel, P.D., 1995, Pesticides in the atmosphere-Distribution, trends, and governing factors, volume 1 of the series-Pesticides in the hydrologic system: Ann Arbor Press, Chelsea, Michigan, $228 \mathrm{p}$.

Maret, T.R., Konrad, C.P., and Tranmer, A.W., 2010, Influence of environmental factors on biotic responses to nutrient enrichment in agricultural streams: Journal of the American Water Resources Association, v. 46, no. 3, p. 498-513, http://doi. org/10.1111/j.1752-1688.2010.00430.x. 
Maret, T.R., MacCoy, D.E., and Carlisle, D.M., 2008, Longterm water quality and biological responses to multiple best management practices in Rock Creek, Idaho: Journal of the American Water Resources Association, v. 44, no. 5, p. $1,248-1,269$.

Meals, D.W., Dressing, S.A., and Davenport, T.E., 2010, Lag time in water quality response to best management practices-A review: Journal of Environmental Quality, v. 39, p. 85-96, http://doi.org/10.2134/jeq2009.0108.

Mebane, C.A., Simon, N.S., and Maret, T.R., 2013, Linking nutrient enrichment and streamflow to macrophytes in agricultural streams: Hydrobiologia, v. 722, no. 1, p. 143-158, http://doi.org/10.1007/s10750-013-1693-4.

Miller, A.J., Schuur, E.A.G., and Chadwick, O.A., 2001, Redox controls of phosphorus pools in Hawaiian montane forest soils: Geoderma, v. 102, p. 219-237.

Miltner, R.J., 2010, A method and rationale for deriving nutrient criteria for small rivers and streams in Ohio: Environmental Management v. 45, p. 842-855, http://doi. org/10.1007/s00267-010-9439-9.

Miltner R.J., and Rankin, E.T., 1998, Primary nutrients and the biotic integrity of rivers and streams: Freshwater Ecology, v. 40, p. $145-158$.

Moulton, S.R., II, Kennen, J.G., Goldstein, R.M., and Hambrook, J.A., 2002, Revised protocols for sampling algal, invertebrate, and fish communities as part of the National Water-Quality Assessment Program: U.S. Geological Survey Open-File Report 02-150, 75 p., https:// pubs.usgs.gov/of/2002/ofr-02-150/index.html.

Mueller D.K., and Spahr, N.E., 2006, Nutrients in streams and rivers across the Nation-1992-2001: U.S. Geological Survey Scientific Investigations Report 2006-5107, 44 p., https://pubs.usgs.gov/sir/2006/5107/.

Mulholland, P.J., Helton, A.M., Poole, G.C., Hall Jr, R.O., Hamilton, S.K., Peterson, B.J., Tank, J.L., Ashkenas, L.R., Cooper, L.W., Dahm, C.N., Dodds, W.K., Findlay, S.E.G., Gregory, S.V., Grimm, N.B., Johnson, S.L., McDowell, W.H., Meyer, J.L., Valett, H.M., Webster, J.R., Arango, C.P., Beaulieu, J.J., Bernot, M.J., Burgin, A.J., Crenshaw, C.L., Johnson, L.T., Niederlehner, B.R., O’Brien, J.M., Potter, J.D., Sheibley, R.W., Sobota, D.J., Thomas, S.M., 2008, Stream denitrification across biomes and its response to anthropogenic nitrate loading: Nature, v. 452, no. 7184, p. 202-205.
Mulholland, P.J., Hall, R.O., Jr., Sobota, D.J., Dodds, W.K., Findlay, S.E.G., Grimm, N.B., Hamilton, S.K., McDowell, W.H., O’Brien, J.M., Tank, J.L., Ashkenas, L.R., Cooper, L.W., Dahm, C.N., Gregory, S.V., Johnson, S.L., Meyer, J.L., Peterson, B.J., Poole, G.C., Valett, H.M., Webster, J.R., Arango, C.P., Beaulieu, J.J., Bernot, M.J., Burgin, A.J., Crenshaw, C.L., Helton, A.M., Johnson, L.T., Niederlehner, B.R., Potter, J.D., Sheibley, R.W., and Thomas, S.M., 2009, Nitrate removal in stream ecosystems measured by $15 \mathrm{~N}$ addition experiments-Denitrification: Limnology and Oceanography, v. 54, no. 3, p. 666-680.

Munn, M.D., Black, R.W., and Gruber, S.J., 2002, Response of benthic algae to environmental gradients in an agriculturally dominated landscape: Journal of the North American Benthological Society, v. 21, p. 221-237.

Munn, M.D., Waite, I.R., Larsen, D.P., and Herlihy, A.T., 2009, The relative influence of geographic location and reach-scale habitat on benthic invertebrate assemblages in six ecoregions: Environmental Monitoring and Assessment, v. 154 , nos. 1-4, p. 1-14.

Munn, Mark, Frey, Jeffrey, and Tesoriero, Anthony, 2010, The influence of nutrients and physical habitat in regulating algal biomass in agricultural streams: Environmental Management, v. 45, no. 3, p. 603-615, http://doi. org/10.1007/s00267-010-9435-0.

Munn, M.D., 2018, The quality of our Nation's waterUnderstanding the influence of nutrients on stream ecosystems in agricultural landscapes-Supplemental data: U.S. Geological Survey data release, https://doi. org/10.5066/F7QZ286J.

National Agricultural Statistics Service, 2008, Agricultural atlas of the United States, 2002: U.S. Department of Agriculture, Census of Agriculture, Ag Atlas Maps, accessed April 26, 2010, at https://www.agcensus.usda.gov/ Publications/2002/Ag_Atlas_Maps/index.asp.

National Agricultural Statistics Service, 2010, Agricultural atlas of the United States-Number of broilers and other meat-type chickens sold, 2007: U.S. Department of Agriculture, Census of Agriculture, map 07-M161, accessed September 1, 2010, at https://www.agcensus.usda.gov/ Publications/2007/Online_Highlights/Ag_Atlas_Maps/ Livestock_and_Animals/Livestock,_Poultry_and_Other_ Animals/07-M161-RGBDot1-largetext.pdf. 
Omernik, J.M., 1987, Ecoregions of the conterminous United States: Annals of the Association of American Geographers, v. 77, no. 1, p. 118-125, 1 plate, scale 1:7,500,000.

Peterson, B.J., Wollheim, W.M., Mulholland, P.J., Webster, J.R., Meyer, J.L., Tank, J.L., Marti, E., Bowden, W.B., Valett, H.M., Hershey, A.E., McDowell, W.H., Dodds, W.K., Hamilton, S.K., Gregory, S., and Morrall, D.D., 2001, Control of nitrogen export from watersheds by headwater streams: Science, v. 292, no. 5514, p. 86-90.

Ponader, K.C., Charles, D.F., and Belton, T.J., 2005, Diatom-based TP and TN inference models and indices for monitoring nutrient enrichment of New Jersey streams: Ecological Indicators, v. 7, p. 79-93, http://doi. org/10.1016/j.ecolind.2005.10.003.

Porter, S.D., Mueller, D.K., Spahr, N.E., Munn, M.D., and Dubrovsky, N.M., 2008, Efficacy of algal metrics for assessing nutrient and organic enrichment in flowing waters: Freshwater Biology, v. 53, p. 1,036-1,054, http:// doi.org/10.1111/j.1365-2427.2007.01951.x.

Pringle, C.M., 1987, Effects of water and substratum nutrient supplies on lotic periphyton growth-An integrated bioassay: Canadian Journal of Fisheries and Aquatic Sciences, v. 44, p. 619-629.

Pringle, C.M., and Bowers, J.A., 1984, An in situ substratum fertilization technique-Diatom colonization on nutrientenriched, sand substrata: Canadian Journal of Fisheries and Aquatic Sciences, v. 41, p. 1,247-1,251.

Puckett, L.J., 1995, Identifying the major sources of nutrient water pollution: Environmental Science and Technology, v. 29 , no. 9 , p. 408A-414A, http://doi.org/10.1021/ es00009a001, accessed June 17, 2010, at http://pubs.acs. org/doi/abs/10.1021/es00009a001.

Puckett, L.J., Tesoriero, A.J., and Dubrovsky, N.M., 2011, Nitrogen contamination of surficial aquifers-A growing legacy: Environmental Science and Technology, v. 45, p. 839-844, http://doi.org/10.1021/es1038358.

Rankin, E.T., Miltner, R.J., Yoder, C.O., and Mishne, D.A., 1999, Association between nutrients, habitat, and the aquatic biota in Ohio rivers and streams: Columbus, Ohio EPA Technical Bulletin MAS/1999-1-1, 78 p.
Riseng, C.M., Wiley, M.J., Black, R.W., and Munn, M.D., 2011, Impacts of agricultural land use on biological integrity-A causal analysis: Ecological Applications, v. 21, no. 8 , p. 3,128-3,146.

Ruddy, B.C., Lorenz, D.L., and Mueller, D.K., 2006, Countylevel estimates of nutrient inputs to the land surface of the conterminous United States, 1982-2001: U.S. Geological Survey Scientific Investigations Report 2006-5012, 17 p., https://pubs.usgs.gov/sir/2006/5012/.

Sakamoto, M., 1966, Primary production by phytoplankton community in some Japanese lakes and its dependence on lake depth: Archiv für Hydrobiologie, v. 62, p. 1-28.

Santhi, C., Allen, P.M., Muttiah, R.S., Arnold, J.G., and Tuppad, P., 2008, Regional estimation of base flow for the conterminous United States by hydrologic landscape regions: Journal of Hydrology, v. 351, p. 139-153.

Sharpley, A., Jarvie, H.P., Buda, A., May, M., Spears, B., and Kleinman, P., 2013, Phosphorus legacy-Overcoming the effects of past management practices to mitigate future water quality impairment: Journal of Environmental Quality, v. 42, p. 1,308-1,326.

Sheibley, R.W., Duff, J.H., and Tesoriero, A.J., 2014, Low transient storage and uptake efficiencies in seven agricultural streams-Implications for nutrient demand: Journal of Environmental Quality, v. 43, no. 6, p. 1,980-1,990, http://doi.org/10.2134/jeq2014.01.0034.

Simon, N.S., Lynch, D., and Gallaher, T.N., 2009, Phosphorus fractionation in sediment cores collected in 2005 before and after onset of an Aphanizomenon flos-aquae bloom in Upper Klamath Lake, OR, USA: Water, Air, and Soil Pollution, v. 204 , no. $1-4$, p. $139-153$.

Smith, V.H., Tilman, G.D., and Nekola, J.C., 1999, Eutrophication-Impacts of excess nutrient inputs on freshwater, marine, and terrestrial ecosystems: Environmental Pollution, v. 100, p. 179-196.

Stevenson, R.J., 1996, Chapter 1-An introduction of algal ecology in freshwater benthic habitats, in Stevenson, R.J., Bothwell, M.L., and Lowe, R.L., eds., Algal Ecology: San Diego, California, Academic Press, 752 p. 
Stevenson, R.J., Rier, S.T., Riseng, C.M., Schultz, R.E., and Wiley, M.J., 2006, Comparing effects of nutrients on algal biomass in streams in two regions with different disturbance regimes and with applications for developing nutrient criteria: Hydrobiologia, v. 561, p. $149-165$.

Stoddard, J.L., Herlihy, A.T., Hill, B.H., Hughes, R.M., Kaufmann, P.R., Klemm, D.J., Lazorchak, J.M., McCormick, F.H., Peck, D.V., Paulsen, S.G., Olsen, A.R., Larsen, D.P., Van Sickle, J., and Whittier, T.R., 2006, Mid-Atlantic Integrated Assessment (MAIA) State of the flowing waters report: Washington, D.C., U.S. Environmental Protection Agency, Office of Research and Development, EPA/620/R-06/001, 85 p.

Suplee, M.W., Watson, V., Teply, M., and McKee, H., 2009, How green is too green? Public opinion of what constitutes undesirable algae levels in streams: Journal of the American Water Resources Association, v. 45, no. 1, p. 123-140.

Tesoriero, A.J., Duff, J.H., Saad, D.A., Spahr, N.E., and Dolock, D.M., 2013, Vulnerability of streams to legacy nitrate sources: Environmental Science and Technology, v. 47, p. 3,623-3,629.

Tesoriero, A.J., Duff, J.H., Wolock, D.M., Spahr, N.E., and Almendinger, J.A., 2009, Identifying pathways and processes affecting nitrate and orthophosphate inputs to streams in agricultural watersheds: Journal of Environmental Quality, v. 38, p. 1,892-1,900.

Tesoriero, A.J., and Puckett, L.J., 2011, $\mathrm{O}_{2}$ reduction and denitrification rates in shallow aquifers: Water Resources Research, v. 47, W12522, 17 p., http:// onlinelibrary.wiley.com/doi/10.1029/2011WR010471/ full.

Triska, F.J., Duff, J.H., and Avanzino, R.J., 1993, The role of water exchange between a stream channel and its hyporheic zone in nitrogen cycling at the terrestrial-aquatic interface: Hydrobiologia, v. 251, p. $167-184$.

U.S. Environmental Protection Agency, 2000, Nutrient criteria technical guidance manual-Rivers and streams: Washington, D.C., U.S. Environmental Protection Agency, Office of Water, EPA 822-B-00002, $253 \mathrm{p}$.
U.S. Environmental Protection Agency, 2006, Wadeable streams assessment-A collaborative survey of the Nation's streams: U.S. Environmental Protection Agency, Office of Research and Development and Office of Water, EPA 841- B-06-002, 98 p., accessed February 27, 2014, at https://nepis.epa.gov/Exe/ ZyPURL.cgi?Dockey=60000FDW.TXT.

U.S. Environmental Protection Agency, 2007, Level III ecoregions of the continental United States: Corvallis, Oregon, U.S. Environmental Protection Agency National Health and Environmental Effects Research Laboratory, 1 sheet, scale 1:7,500,000, accessed February 27, 2014, at https://www.epa.gov/ eco-research/level-iii-and-iv-ecoregions-continentalunited-states.

U.S. Geological Survey, 2007, National land cover database 2001 (NLCD 2001), version 1.0: U.S. Geological Survey database, accessed May 25, 2007, at https://www.mrlc.gov/nlcd2011.php.

U.S. Geological Survey, 2014, Base-flow index grid for the conterminous United States: U.S. Geological Survey website, accessed May 15, 2014, at https:// water.usgs.gov/GIS/metadata/usgswrd/XML/ bfi48grd.xml.

Van Dam, H., Mertens, A., and Sinkeldam, J., 1994, A coded checklist and ecological indicator values of freshwater diatoms from the Netherlands: Netherlands Journal of Aquatic Ecology, v. 28, no. 1, p. 117-133.

Van Sickle, J., Hawkins, C.P., Larsen, D.P., and Herlihy, A.T., 2005, A null model for the expected macroinvertebrate assemblage in streams: Journal of the North American Benthological Society, v. 24, no. 1, p. 178-191.

Vitousek, P.M., Aber, J.D., Howarth, R.W., Likens, G.E., Matson, P.A., Schindler, D.W., Schlesinger, W.H., and Tilman, D.G., 1997, Human alteration of the global nitrogen cycle-Sources and consequences: Ecological Applications, v. 7 , no. 3, p. 737-750, accessed February 27, 2014, at http://onlinelibrary.wiley.com/doi/10.1890/10510761(1997)007\%5B0737:HAOTGN\%5D2.0.CO \%3B2/abstract. 
Wahl, K.L., and Wahl, T.L., 1988, Effects of regional groundwater declines on streamflows in the Oklahoma Panhandle, in Proceedings of Symposium on Water-Use Data for Water Resources Management: Tucson, Arizona, American Water Resources Association, p. 239-249, accessed February 27, 2014, at https://www.usbr.gov/pmts/hydraulics_lab/twahl/ bfi/bfi_beaver_river.pdf.

Wahl, K.L., and Wahl, T.L., 1995, Determining the flow of Comal Springs at New Braunfels, Texas, in Proceedings of Texas Water '95, August 16-17, 1995, San Antonio, Texas: American Society of Civil Engineers, p. 77-86, accessed March 20, 2014, at https://www.usbr.gov/pmts/hydraulics lab/twahl/bfi/texaswater95/comalsprings.html.

Waite, I.R., 2013, Development and application of an agricultural intensity index to invertebrate and algal metrics from streams at two scales: Journal of the American Water Resources Association (JAWRA), v. 49, no. 2, p. 431-448, http://doi.org/10.1111/jawr.12032.

Waite, I.R., Brown, L.R., Kennen, J.G., May, J.T., Cuffney, T.F., Orlando, J.L., and Jones, K.A., 2010, Comparison of watershed disturbance predictive models for stream benthic macroinvertebrates for three distinct ecoregions in western US: Ecological Indicators, v. 10, no. 6, p. 1,125-1,136, http://doi.org/10.1016/j.ecolind.2010.03.011.
Welch, E.B., Jacoby, J.M., Horner, R.R., and Seeley, M.R. 1989, Nuisance biomass levels of periphytic algae in streams: Hydrobiologia, v. 157, p. 161-168.

Wharton, G., Cotton, J.A., Wotton, R.S., Bass, J.A.B., Heppell, C.M., Trimmer, M., Sanders, I.A., and Warren, L.L., 2006, Macrophytes and suspension-feeding invertebrates modify flows and fine sediments in the Frome and Piddle catchments, Dorset (UK): Journal of Hydrology, v. 330, p. 171-184.

Williamson, A.K., Munn, M.D., Ryker, S.J., Wagner, R.J., Ebbert, J.C., and Vanderpool, A.M., 1998, Water Quality in the Central Columbia Plateau, Washington and Idaho, 1992-95: U.S. Geological Survey Circular 1144, p. 35, https://pubs.usgs.gov/circ/circ1144/.

Wolock, D.M., 2003, Base-flow index grid for the conterminous United States: U.S. Geological Survey OpenFile Report 03-263, digital dataset, https://pubs.er.usgs.gov/ publication/ofr03263.

Wong, S.L., and Clark, B., 1979, The determination of desirable and nuisance plant levels in streams: Hydrobiologia, v. 63, no. 3, p. 223-230. 


\section{Glossary}

agricultural management practices Methods used as part of crop cultivation and livestock husbandry (such as irrigation, fertilization, or integrated pest management) to maximize product yields, control soil erosion, maintain soil quality, and (or) minimize any adverse effects on water quality or ecosystem health.

agricultural stream A stream draining a watershed with more than 25 percent agricultural land (cropland or pasture) and 5 percent or less of urban land.

algae Chlorophyll-bearing nonvascular, primarily aquatic species that have no true roots, stems, or leaves; most algae are microscopic, but some species can be as large as vascular plants.

algal bloom Sudden spurts of algal growth, which can affect water quality adversely and indicate potentially hazardous changes in local water chemistry. Dissolved oxygen in the water is consumed when algae grows and decomposes, which can lead to death of aquatic animals if the oxygen deficit is severe.

ammonia A compound of nitrogen and hydrogen $\left(\mathrm{NH}_{3}\right)$ that is a common by-product of animal waste. Ammonia readily converts to nitrate in soils and streams when oxygen is present.

anoxic Groundwater that has no dissolved oxygen or a very low concentration of dissolved oxygen (less than $0.5 \mathrm{mg} / \mathrm{L})$.

Aquatic-Life Criteria Water-quality guidelines established by the U.S. Environmental Protection Agency (EPA) for protection of aquatic life. Often refers to EPA water-quality criteria for protection of aquatic organisms.

aquatic vegetation A general term that includes all aquatic photosynthetic organisms, as in algae, aquatic plants, and moss.

base flow The sustained low flow of a stream, following extended periods of minimal precipitation, during which streamflow is derived primarily from groundwater.

base-flow index (BFI) The ratio of base flow to total flow for a given period. bed sediment Sediment particles, including eroded soil and organic matter, deposited at the bottom of a stream, lake, or ocean).

benthic Refers to organisms that live on the bottoms of lakes, streams, or oceans.

benthic invertebrates Insects, mollusks, crustaceans, worms, and other organisms without a backbone that live in, on, or near the bottom of lakes, streams, or oceans.

best management practice (BMP) An agricultural practice that has been determined to be an effective, practical means of preventing or reducing nonpoint source pollution.

biological assessment An assessment of environmental quality by means of sampling and analyzing the characteristics of biological communities.

biological community A collection of species that inhabit a particular ecosystem or place. Distinctions among communities are typically arbitrary and reflect convenient categories of general types of organisms, such as algal, macroinvertebrate, and fish communities that inhabit a particular stream.

biological condition A measure of the degree to which biological communities differ from a natural (undisturbed or reference) state; generally, biological indicators at a site are compared with those at relatively natural sites to assess status of, or change in, condition.

biomass The total weight or volume of living material or type of organism within a given area and at a particular time.

channelization The straightening and deepening of a stream channel to permit the water to move faster or to drain a wet area for farming.

chlorophyll A green photosynthetic pigment found in most plants, algae and cyanobacteria.

community In ecology, the species that interact in a common area.

concentration The amount or mass of a substance present in a given volume or mass of sample. Usually expressed as micrograms per liter (water sample) or micrograms per kilometer (sediment or tissue sample). 
Corn Belt The area of the Great Plains and the Midwest where corn and soybeans are the principal crops. It generally includes Illinois, Indiana, Iowa, Nebraska, and Ohio, as well as parts of adjoining states.

cyanobacteria A group of microorganisms that are related to bacteria but are capable of photosynthesis.

denitrification A process by which oxidized forms of nitrogen such as nitrate $\left(\mathrm{NO}_{3}^{-}\right)$are reduced to form nitrites, nitrogen oxides, ammonia, or free nitrogen: commonly brought about by the action of denitrifying bacteria and usually resulting in the escape of nitrogen to the air.

diatoms Single-celled, colonial, or filamentous algae with siliceous cell walls constructed of two overlapping parts.

discharge The volume of fluid passing a point per unit of time, commonly expressed in cubic meters per second.

dissolved oxygen Oxygen dissolved in water; one of the most important indicators of the condition of a water body. Dissolved oxygen is necessary for the life of fish and most other aquatic organisms.

diurnal cycle Any pattern that recurs every 24 hours. In the context of dissolved oxygen in streams, it refers to daily fluctuation associated with the increase of oxygen during daylight as part of the photosynthetic process, followed by a decrease in the nighttime as part of the respiration process.

drainage basin The land area drained by a river or stream.

ecoregion A geographic area of similar climate, landform, soil, potential natural vegetation, and hydrology.

ecosystem The interacting populations of plants, animals, and microorganisms occupying an area, plus their physical environment.

EPT richness An index based on the sum of the number of taxa in three insect orders, Ephemeroptera (mayflies), Plecoptera (stoneflies), and Trichoptera (caddisflies), that are composed primarily of species considered to be relatively intolerant to environmental alterations. eutrophication The process by which water becomes enriched with plant nutrients, most commonly phosphorus and nitrogen.

fertilizer Any of a large number of natural or synthetic materials, including manure, nitrogen, phosphorus, and potassium compounds, spread on or worked into soil to increase its fertility.

food web An interconnected network of feeding linkages among organisms in an ecosystem.

groundwater Generally, any water that exists beneath the land surface, but more commonly applied to water in fully saturated soils and geologic formations.

habitat The living space and environmental setting of a particular organism.

hydrograph Graph showing variation of water elevation, velocity, streamflow, or other property of water with respect to time.

hyporheic zone The hyporheic zone is a part of the groundwater interface in streams where a mixture of surface water and groundwater can be found.

indicator An organism, species, assemblage, or community characteristic of a particular habitat, or indicative of a particular set of environmental conditions.

invertebrate An animal having no backbone or spinal column (see also benthic invertebrate).

macroinvertebrates Animals that do not have backbones, such as worms, clams, crustaceans, and insects; "macro" refers to those animals that can be easily seen without magnification and are operationally defined here as those that are retained by a net with $0.5-\mathrm{mm}$ mesh size.

macronutrients A chemical element or substance required in relatively large amounts for the normal growth and development of organisms.

mesotrophic Systems with moderate organic and nutrient enrichment.

microbe Microorganisms such as bacteria, algae, diatoms, plankton, and fungi. 
micrograms per liter ( $\mu \mathrm{g} / \mathbf{L}) \quad$ A unit expressing the concentration of constituents in solution as weight (micrograms) of solute per unit volume (liter) of water; equivalent to one part per billion in most stream water and groundwater $1,000 \mu \mathrm{g} / \mathrm{L}=1 \mathrm{mg} / \mathrm{L}$.

milligrams per liter (mg/L) A unit expressing the concentration of chemical constituents in solution as weight (milligrams) of solute per unit volume (liter) of water; equivalent to one part per million in most stream water and groundwater.

NAWOA National Water-Quality Assessment Project of the U.S. Geological Survey. NAWQA was initiated in 1991 to develop long-term consistent and comparable information on streams, rivers, groundwater, and aquatic systems in support of national, regional, State, and local information needs and decisions related to water-quality management and policy.

nitrate An ion consisting of nitrogen and oxygen $\left(\mathrm{NO}_{3}^{-}\right)$. Nitrate is a plant nutrient and is very mobile in soils.

Nitrate is a compound containing nitrogen that can exist in the atmosphere or as a dissolved gas in water and which can have harmful effects on humans and animals. Nitrates in water can cause severe illness in infants and domestic animals. A plant nutrient and inorganic fertilizer, nitrate is found in septic systems, animal feed lots, agricultural fertilizers, manure, industrial waste waters, sanitary landfills, and garbage dumps.

nitrogen A naturally occurring chemical element and an important ingredient in many organic chemicals and proteins. It is also an important nutrient for plants.

nonpoint source A pollution source that cannot be defined as originating from discrete points such as pipe discharge. Areas of fertilizer and pesticide applications, atmospheric deposition, manure, and natural inputs from plants and trees are types of nonpoint source pollution.

nonpoint source contaminant A substance that pollutes or degrades water that comes from lawn or cropland runoff, the atmosphere, roadways, and other diffuse sources.

nonpoint-source water pollution Water contamination that originates from a broad area (such as leaching of agricultural chemicals from crop land) and enters the water resource diffusely over a large area.

nutrient Element or compound essential for animal and plant growth. Common nutrients in fertilizer include nitrogen, phosphorus, and potassium. Includes both macro- and micronutrients.

oligotrophic Systems with low organic matter and nutrients. Normally used in the context of lakes, but is sometimes used for streams.

oxic Groundwater or surface water that has a concentration of dissolved oxygen greater than or equal to 0.5 milligrams per liter.

oxygen $\left(\mathbf{O}_{2}\right)$ The most abundant element in nature and is essential for animal life because it is used in respiration.

periphyton Organisms that grow on underwater surfaces, including algae, bacteria, fungi, and protozoa.

phosphorus A nutrient essential for growth that can play a key role in stimulating aquatic growth in lakes and streams.

photosynthesis Synthesis of chemical compounds by organisms with the aid of light. Carbon dioxide is used as raw material for photosynthesis and oxygen is a product.

phytoplankton That part of the plankton community comprised of tiny plants; for example, algae and diatoms.

point source A source at a discrete location such as a discharge pipe, drainage ditch, tunnel, well, concentrated livestock operation, or floating craft.

primary producer Organisms-typically plants - that produce their own energy through photosynthesis.

redox condition As used in this report, redox condition refers to the position that a system is in for the redox scale between very oxidizing and very reducing.

reference The least-disturbed condition available in an ecoregion.

residence time The amount of time that a solute, particle, organism, or other entity spends within a given environmental medium.

respiration A process in living organisms involving the production of energy, typically with the intake of oxygen and the release of carbon dioxide from the oxidation of complex organic substances.

riparian Areas adjacent to rivers and streams with a high density, diversity, and productivity of plant and animal species relative to nearby uplands. 
riparian zone Pertaining to or located on the bank of a body of water, especially a stream.

runoff Excess rainwater or snowmelt that is transported to streams by overland flow, tile drains, or groundwater.

sediment Particles, derived from rocks or biological materials that have been transported by a fluid or other natural process, suspended, or settled on the streambed.

sinuosity The ratio of the channel length between two points on a channel to the straight-line distance between the same two points; a measure of meandering.

species Populations of organisms that may interbreed and produce fertile offspring having similar structure, habits, and functions.

statistics A branch of mathematics dealing with the collection, analysis, interpretation, and presentation of masses of numerical data.

streamflow The amount of water flowing in a river.

stream reach A continuous part of a stream between two specified points.

stressor Factors that adversely affect - and therefore degrade-aquatic ecosystems. Stressors may be chemical (for example, excess nutrients), physical (for example, excess sediments on the streambed), or biological (for example, competing invasive species).

substrate The surface beneath a wetland, lake, or stream in which organisms grow or to which organisms are attached.

substrate size The diameter of streambed particles such as clay, silt, sand, gravel, cobble and boulders.

subsurface tile-drain systems Perforated pipes that are buried in the ground to reduce the water content of poorly drained soils and divert shallow groundwater to nearby streams.

surface runoff The flow of water over the land surface, usually in response to intense rainfall or snowmelt events, irrigation, or rainfall on saturated soils, snow, or impervious surfaces (such as pavement).

surface water An open body of water, such as a lake, river, or stream.

suspended sediment Particles of rock, sand, soil, and organic detritus carried in suspension in the water column, in contrast to sediment that moves on or near the streambed.

suspended-sediment concentration The velocityweighted concentration of suspended sediment in the sampled zone (from the water surface to a point approximately 0.3 foot above the bed); expressed as milligrams of dry sediment per liter of watersediment mixture, in milligrams per liter.

taxon (plural, taxa) A taxonomic category or group, such as phylum, order, family, genus or species.

tile drain A buried perforated pipe designed to remove excess water from soils; may or may not be connected $t$ the surface.

tolerant (or tolerant taxa) Those taxa that are adaptable to (tolerant of) human alterations to the environment and often increase in number when human alterations occur.

total nitrogen The sum of inorganic (nitrate, nitrite, ammonia) and organic forms of nitrogen.

total phosphorus The sum of inorganic and organic forms of phosphorus.

transformation The conversion of one compound to another through either abiotic or biotic processes.

undeveloped stream A stream draining a watershed with 25 percent or less of agricultural land and 5 percent or less of urban land.

vulnerability The tendency or likelihood for contaminants to reach a specified position in the groundwater system after introduction at some location above the uppermost aquifer. The vulnerability of a groundwater resource to contamination depends on its intrinsic susceptibility as well as the locations and types of sources of naturally occurring and anthropogenic contamination, relative location of wells, and the fate and transport of the contaminant(s).

watershed The land area that drains into a particular stream, river, lake, estuary, or coastal zone. See drainage basin. 


\section{Acknowledgments}

This study would not have been possible without a great deal of effort by numerous USGS staff. The authors would like to thank the scientists on the Nutrient Effects Team, which consisted of individuals from 10 USGS Water Science Centers and the National Research Program. We also thank all the scientists and technicians that spent many long days collecting and processing data critical to this study. We wish to specifically thank the following individuals and organizations for their help at various stages of this study.

Scientists on the Nutrient Effects Team included: Jill Frankforter, Dan Calhoun, Patrick Moran, John Duff, Jim Tesoriero, Ian Waite, Robert Black, Terry Maret, Chris Mebane, Ron Zelt, Jeff Frey, Brian Caskey, Kathy Lee, Holly Weyers, Jerad Bales, Billy Justus, and Mark Nardi.

Technical Advisors included: Terry Short (USGS), Frank Triska (USGS), Mike Wiley

(University of Michigan) and Patrick Mulholland (Oak Ridge National Laboratory).

We thank the many reviewers for their helpful suggestions. USGS reviewers included Cathy M. Tate, Karen Murry, Terry Short, and Neil Dubrovsky. External reviewers included Robert Miltner (Ohio Environmental Protection Agency), M.J. Paul (Tetra Tech), Shivi Selveratnam (Indiana Department of Environmental Management), Mark Walbidge (U.S. Department of Agriculture), A.J. Smith (New York Department of Environmental Quality), and Tina Laidlaw (EPA).

Publishing support provided by the U.S. Geological Survey

Scientific Publishing Network, Tacoma Publishing Service Centers

Technical editor: Linda Rogers

Layout Production: Sharon Wahlstrom

Graphic Design: William Gibbs

For more information concerning the research in this report, contact:

National Water-Quality Program

U.S. Geological Survey

413 National Center

12201 Sunrise Valley Drive

Reston, VA 20192

or visit our Web site at:

https://water.usgs.gov/nawqa/ 


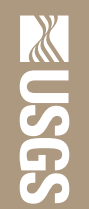

$\stackrel{\frac{7}{10}}{\frac{1}{2}}$

产

을

亭

空

言

के

言

产

o

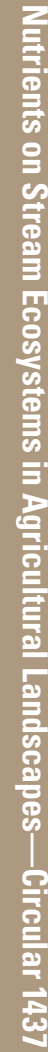

ISSN 2330-5703 (online)

http://dx.doi.org/10.3133/cir1437 